Portland State University

PDXScholar

1986

Geology of the Willamette Pass area, Cascade

Range, Oregon

Neil M. Woller

Portland State University

Follow this and additional works at: https://pdxscholar.library.pdx.edu/open_access_etds

Part of the Geology Commons

Let us know how access to this document benefits you.

Recommended Citation

Woller, Neil M., "Geology of the Willamette Pass area, Cascade Range, Oregon" (1986). Dissertations and Theses. Paper 3655.

https://doi.org/10.15760/etd.5543

This Thesis is brought to you for free and open access. It has been accepted for inclusion in Dissertations and Theses by an authorized administrator of PDXScholar. Please contact us if we can make this document more accessible: pdxscholar@pdx.edu. 
AN ABSTRACT OF THE THESIS OF Neil M. Woller for the Master of Science in Geology presented November 12, 1986.

Title: Geology of the Willamette Pass area, Cascade Range, Oregon .

APPROVED BY MEMBERS OF THE THESIS COMMITTEE:
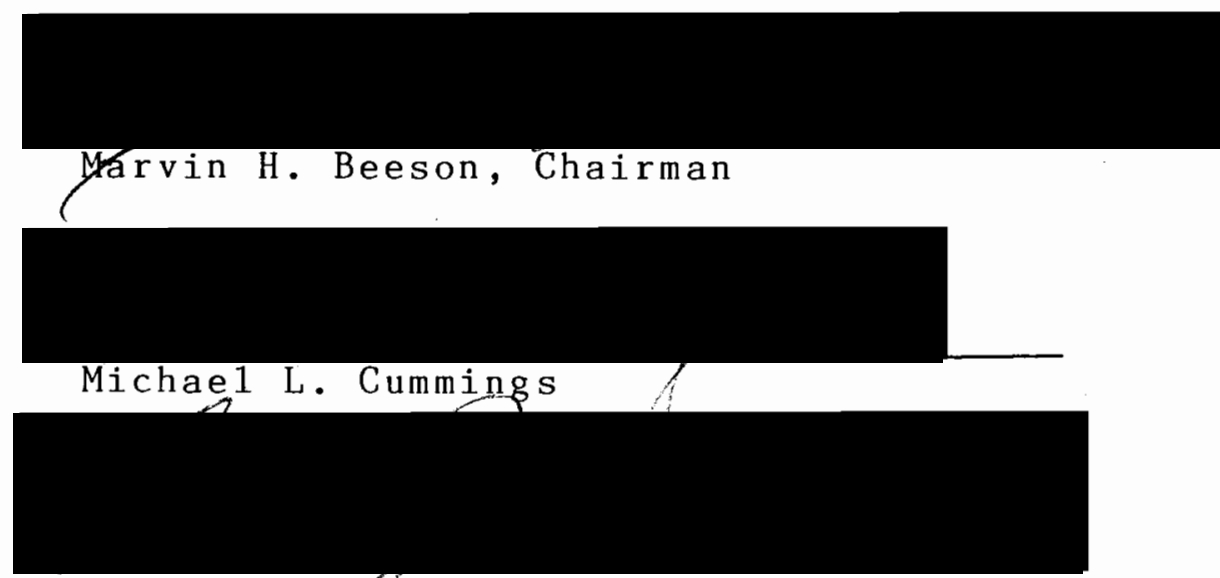

Ansel G. Joknson

The Willamette Pass area is situated at the intersection of two hypothesized structural features, the Western Cascade-High Cascade boundary and the Eugene-Denio lineament. It is of interest due to its designation by the U.S. Department of the Interior as a Known Geotherma1 Resource Area.

Volcanic rocks of 0ligocene to Pleistocene age are exposed in the study area. The oldest rocks are the 01 igocene-Miocene lavas, undifferentiated, which are a diverse unit of ignimbrites and intermediate to silicic 
flows. The Oligocene-Miocene rhyodacites are a stratigraphically equivalent unit which is predominantly composed of aphyric rhyodacite flows. Middle Miocene volcanism produced the basaltic lavas of Tumblebug Creek and the andesitic lavas of Moss Mountain. The predominantly basaltic and basaltic andesite High Cascade volcanism began around $5.5 \mathrm{~m} . \mathrm{y} . \mathrm{B} . \mathrm{P}$. and continued into the Pleistocene.

Uplift of the Western Cascade Range occurred between 4.32 and $1.98 \mathrm{~m} \cdot \mathrm{y} . \mathrm{B} . \mathrm{P}$. and is marked in the stratigraphic record by an unconformity present in most of the study area. The unconformity becomes difficult to recognize in the eastern portion of the study area. It is possible that the southern extension of the north-trending Waldo Lake fault extends into the eastert part of the study area and is the structure that accommodated Western Cascades uplift. Reevaluation of the Groundhog Creek lineament has led to the conclusion that it could be caused by homoclinal folding. Faulting is not recognized in middle Miocene rocks along the lineament, but is equivocal in underlying rocks.

Northwest-trending faults were not found along the trend of the northwest-trending Eugene-Denio lineament. 


\title{
GEOLOGY OF THE WILLAMETTE PASS AREA \\ CASCADE RANGE, OREGON
}

\section{by}

NEIL M. WOLLER

A thesis submitted in partial fulfillment of the requirements for the degree of

\author{
MASTER OF SCIENCE \\ in \\ GEOLOGY
}

Portland State University

1986 
TO THE OFFICE OF GRADUATE STUDIES AND RESEARCH:

The members of the committee approve the thesis of Neil M. Woller presented November 12, 1986.

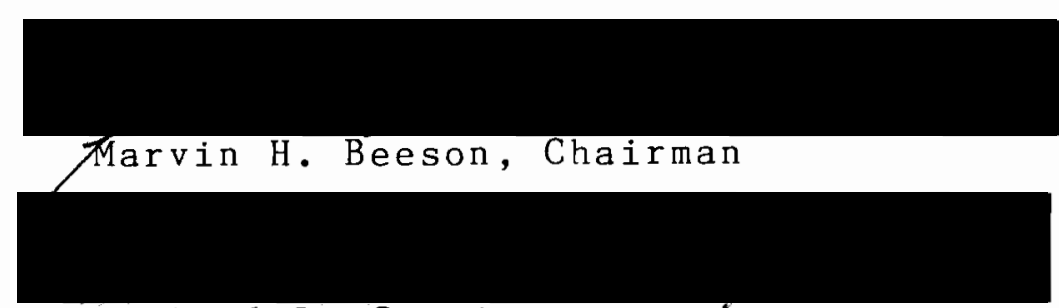

$$
\text { Michael L. Cummings }
$$

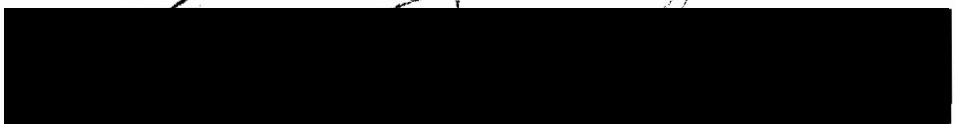

Ansel G. Jøhnson

APPROVED :

Paul E. Hammond, Head of Geology

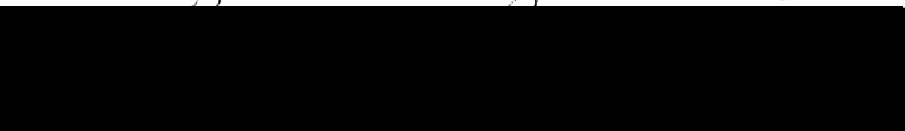

Bernard Ross, Dean of Graduate Studies and Research 


\section{ACKNOWLEDGMENTS}

I wish to express my gratitude to my major professor, Marvin Beeson, and the other members of my thesis committee, Michael Cummings and Ansel Johnson, for their constructive criticism of this work and their excellent classroom instruction.

Very special thanks are due George Priest, whose guidance, patience, and friendship were instramental in my completion of this work. Discussions with George Priest and Gerald Black, who mapped an adjoining study area, were very helpful. Paul Staub made available a good quality map base, for which I am very grateful.

My parents, Howard and Ruth Woller, encouraged me at all times, and came through when it counted. Their support, both spiritual and financial, is greatly appreciated. 
TABLE OF CONTENTS

PAGE

ACKNOWLEDGEMENTS ........................

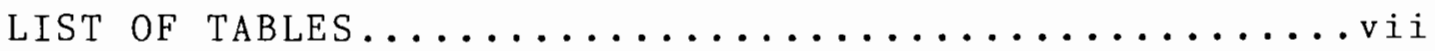

LIST OF FIGURES $\ldots \ldots \ldots \ldots \ldots \ldots \ldots \ldots \ldots \ldots \ldots \ldots \ldots \ldots \ldots \ldots \ldots \ldots$

CHAPTER

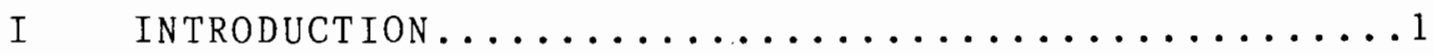

High Cascade-Western Cascade boundary........

Eugene-Denio lineament................

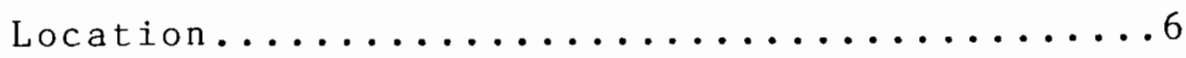

Previous work.....................

I I VOLCANIC StRatigRaPHY $\ldots \ldots \ldots \ldots \ldots \ldots \ldots \ldots$

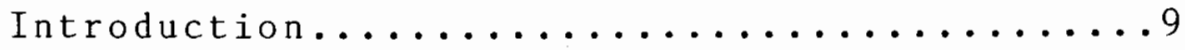

01 igocene-Miocene lavas, undifferentiated....10

01igocene-Miocene rhyodacites............15

Lavas of Tumblebug Creek................

Lavas of Moss Mountain............... 17

High Cascade lavas....................

Lower High Cascade lavas............... 1

Upper High Cascade lavas..............22

Mazama pumice-fall deposit.............. 24

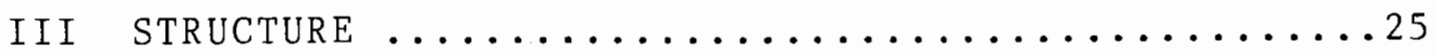

Introduction........................ 5 
Discussion of the Groundhog Creek lineation..25

A discussion of possible structure in

the upper Salt Creek area..........28

Northwest-trending structures.............29

Discussion of the Eugene-Denio 1ineament....29

0ther northwest-trending structures........31

Northeast-trending structures.................

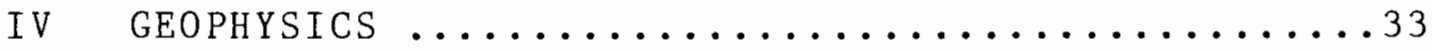

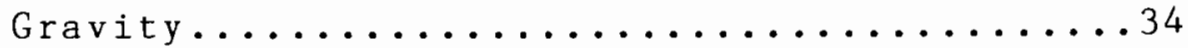

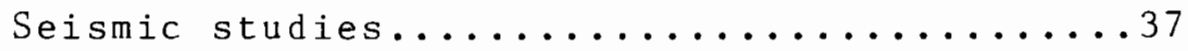

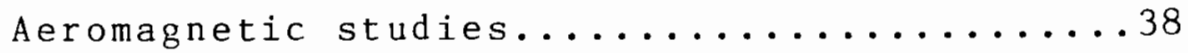

Heat flow and geothermal studies...........38

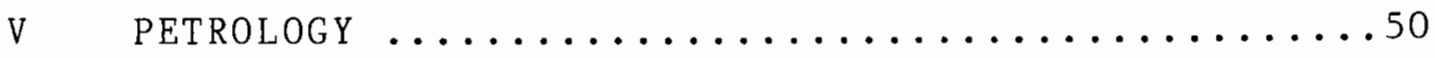

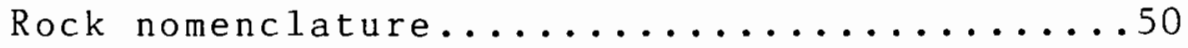

Analytical methods.......................

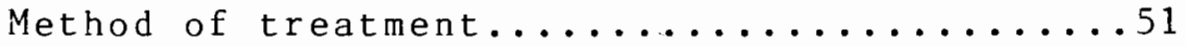

01 igocene-Miocene rhyodacites............60

01 igocene-Miocene lavas, undifferentiated...662

Lavas of Tumblebug Creek...............64

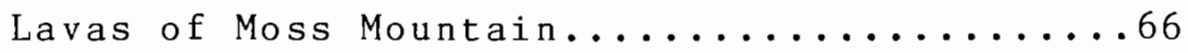

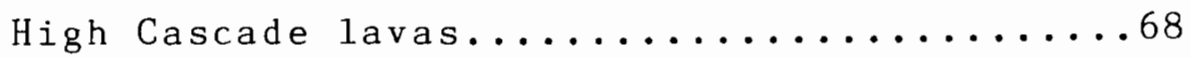

Discussion........................

Comparison of the chemistry of the lavas of Willamette Pass with other arc

lavas...........................

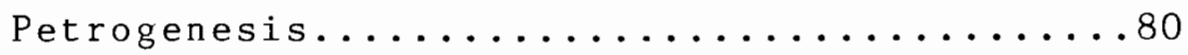


Speculations on the petrogenesis of the

lavas of Tumblebug Creek and High

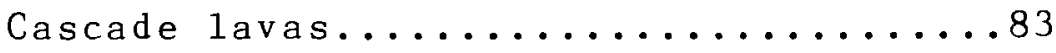

Discussion of samples P-PHL and P-Notch.....91

Speculations on the petrogenesis of the

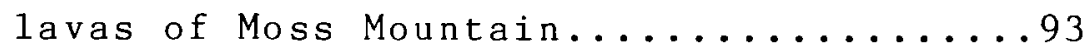

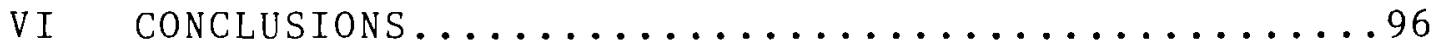

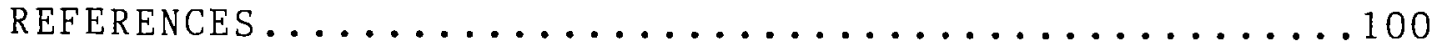

APPENDIX I CHEMICAL ANALYSES...................

APPENDIX II RADIOMETRIC DATE DATA................ 


\section{LIST OF TABLES}

TABLE

PAGE

2.1 Stratigraphic units of some regional geologic

studies in the Oregon Cascades.............11

2.2 Stratigraphy of the Willamette Pass area........12

4.1 Water chemistry and calculated reservoir

temperatures of thermal springs in the

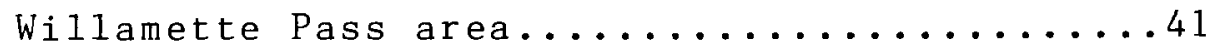

5.1 Symbols used on the chemical diagrams of this

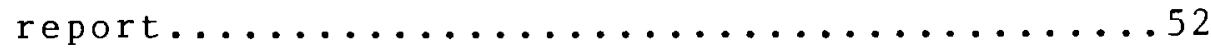

5.2 Petrography of the rocks of the Willamette Pass

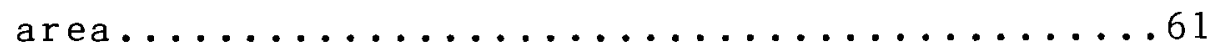

5.3 Comparison of the chemistry of Willamette Pass

rocks with rocks of other volcanic arcs......77

5.4 Chemistry of typical phenocryst minerals in

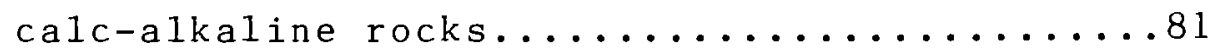




\section{LIST OF FIGURES}

FIGURE

PAGE

1.1 Location of the Willamette Pass study area........2

1.2 Structural and volcanic features of the Oregon

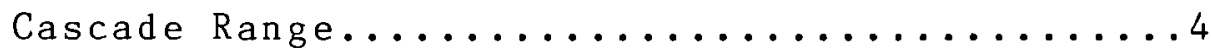

4.1 Residual gravity of the Willamette Pass area.....35

4.2 Heat flow and shallow Curie point temperatures

from aeromagnetic studies................. 39

4.3 Models showing possible origins of Cascade

thermal springs and the heat flow anomaly....44

4.4 Temperature gradient in the Sunedco well near

Breitenbush Hot Springs.............48

5.1 Silica versus total iron, magnesia, and titania...53

5.2 Silica versus calcium, sodium, and alumina.......54

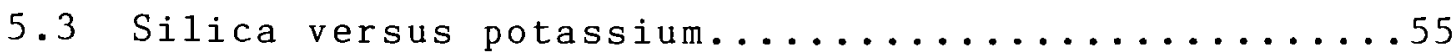

5.4 Silica versus total alkalies and $\mathrm{FeO} / \mathrm{Mg} 0 \ldots \ldots \ldots 56$

5.5 Magnesium versus rubidium, barium, and strontium...57

5.6 Magnesium versus chromium, cobalt, and nickel....58

5.7 Nepheline-quartz-hypersthene-olivine

quadrilateral (basalt tetrahedron).........59

5.8 Silica versus $\mathrm{CaO} / \mathrm{A} 1203$ and $\mathrm{CaO} / \mathrm{Fe} 0 * \ldots \ldots \ldots \ldots 6$

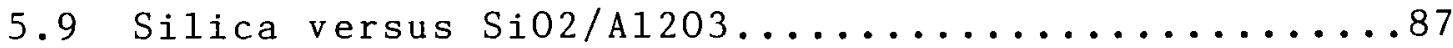




\section{CHAPTER I}

\section{INTRODUCTION}

\section{High Cascade-Western Cascade boundary}

Baldwin (1964) and Peck and others (1964) divided the Oregon Cascade Range into the Western Cascades and High Cascades physiographic provinces. Both provinces were formed by the processes attending the subduction of the Juan de Fuca plate beneath the North American plate. Whereas the High Cascade province is the site of voluminous Quaternary volcanism, the Western Cascades is, in effect, a fossil (Oligocene and Miocene) arc. However, young (less than $5 \mathrm{Ma}$ ) volcanic vents are common along the eastern margin of the Western Cascades, and a few young (less than 5 Ma) volcanic centers are located within the center of the province (Peck and others, 1964; Luedke and Smith, 1982). The active volcanic arc evidently migrated eastward between 8 and 5 Ma (Peck and others, 1964; Priest and others, 1983; Blackwe11 and others, 1982).

The Western Cascade Range has experienced substantial uplift with consequent dissection (e.g., Priest and others, 1983). There is, however, no evidence that the High Cascade Range has experienced uplift in the central Oregon Cascades. Rather, it appears that the High Cascade platform has been a constructional basin, with High Cascade 


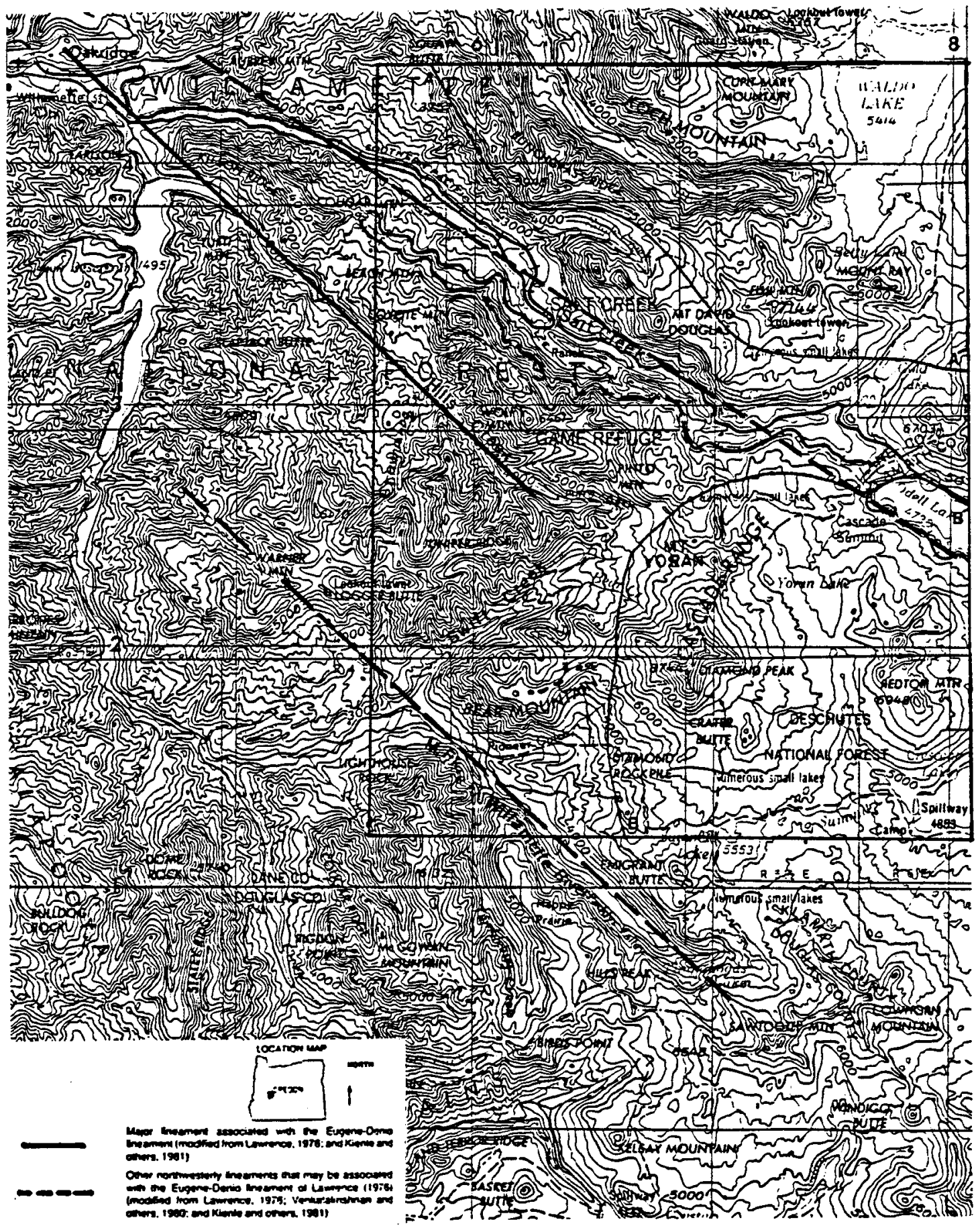

0

5

10

15

20 Statute Miles

\begin{tabular}{lllllll}
\hline 0 & 5 & 10 & 15 & 20 & 30 Kilometors \\
\hline
\end{tabular}

Flgure 1.1. Location of the N1llamette Pass study area. Rectargle encloses area of Plate 1. A-A' is the north boundary of the study area, $B-B^{\prime}$ is the southeast boundary. 
lavas "leaking" out into lows in the Western Cascades "skyline" formed by the westward-flowing antecedent streams. The evolution of the Western Cascades and the High Cascade Range has therefore taken different paths during the last $5 \mathrm{Ma}$.

The heat flow anomaly associated with arc volcanism extends westward into the Western Cascade Range (Figures 1.2 and 4.2; Blackwell and others, 1982; Black and others, 1983). The narrow transition zone between the low heat flow of the Willamette Valley, Coast Range, and most of the Western Cascade Range and the high heat flow of the High Cascade Range and eastern Western Cascade Range (B1ack and others, 1983; Blackwell and others, 1978; Blackwell and Steele, 1983) appears to coincide in the central Oregon Cascades with a north-northeasterly residual gravity low identified by Couch and others (1982a; 1982b; Figure 4.1) as a fracture and fault zone bounding the High Cascades. The Willamette Pass area lies at the boundary of the two physiographic provinces. The western and central parts of the study area have the mature topography and Tertiary volcanic rocks that are typical of the Western Cascades. In the extreme eastern part of the study area, the topography, primarily the product of constructional Quaternary volcanism and modified principally by glaciation, is typical of the High Cascade province. The nature of the transition from the deeply dissected Western Cascade Range to the younger, primarily constructional, 


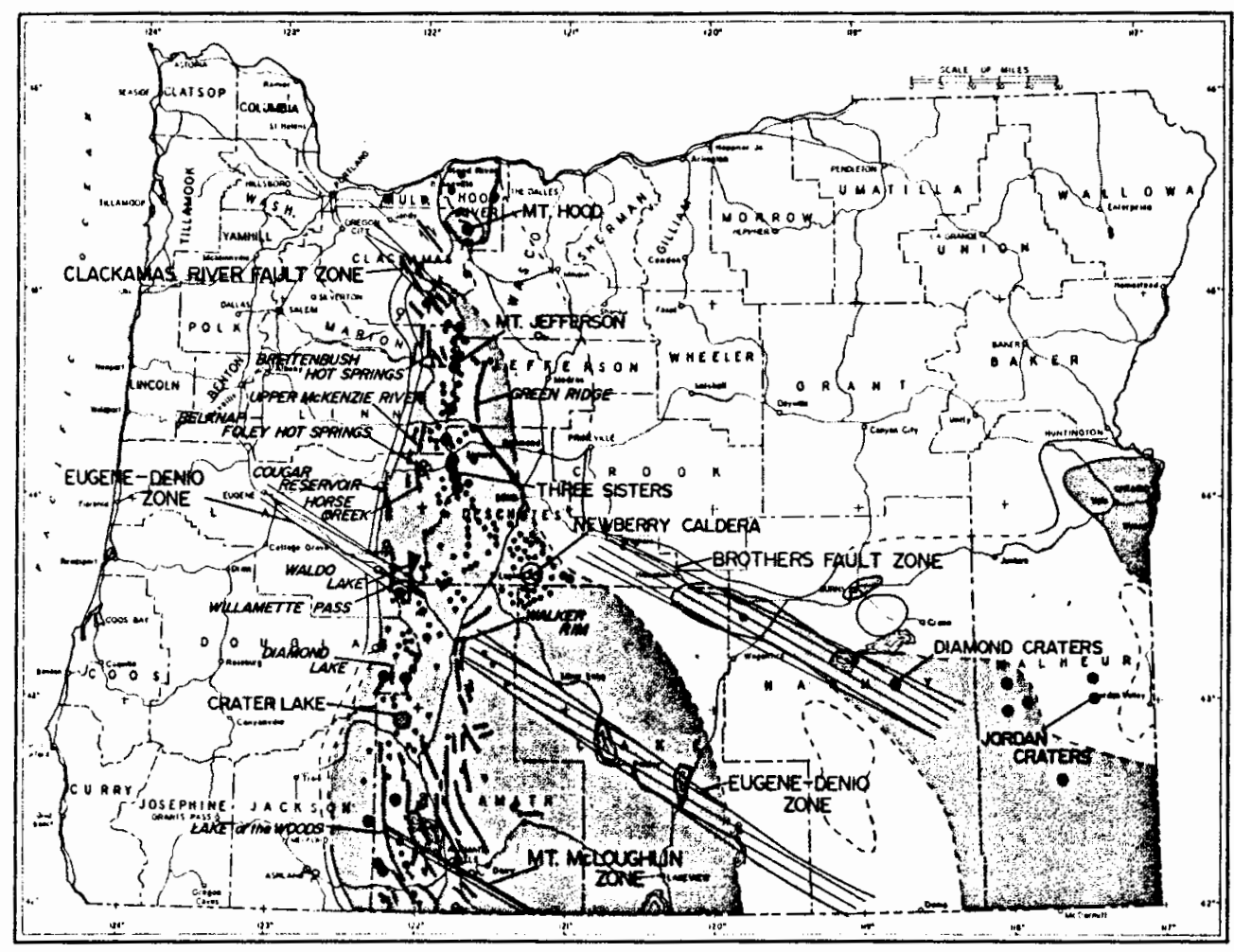

EXPLANATION

Heal flow over $100 \mathrm{~mW} / \mathrm{m}^{2}$

= Heat thow between $100 \mathrm{~mW} / \mathrm{m}^{2}$ and $80 \mathrm{~mW} / \mathrm{m}^{2}$

S = Major northwest-trending lineaments; names are from Lawrence (1976); Clackamas River fault zone is from Anderson (1978) and Beeson and others (in preparation)

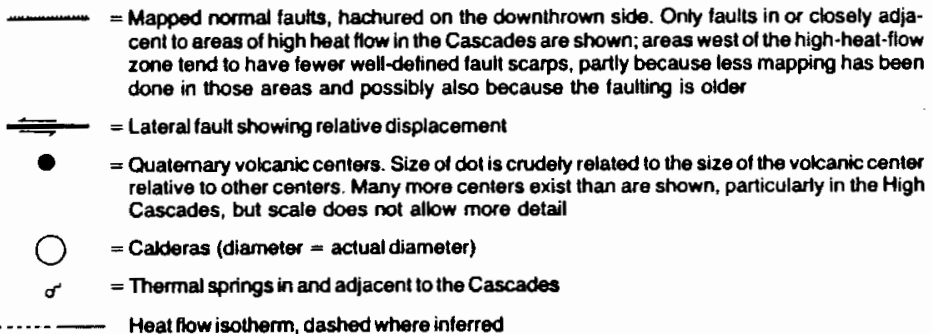

Map showing some major faults, lineaments, hot springs, and Quaternary volcanic centers relative to zones of anomalously high heat flow in the Cascade Range and adjacent areas of Oregon. Geologic data are from Wells and Peck (1961), Hales (1975), Peterson and others (1976), Walker (1977), Barnes (1978), Beeson and Moran (1979), Brown and others (1980a), Hammond and others (1980), Auramenko (1981), Flaherty (1981), Priest and others (1982a), Smith and others (1982), Woller and Black (Chapter 6), and Beeson and others (in preparation). Heat flow data are from Blackwell and others (1978) and Black and others (Chapter 7 ).

Figure 1.2. Structural and volcanic features of the Oregon Cascade Range. (From Priest and others, 1983.) 
High Cascade Range is one of the subjects of this study. Willamette Pass is an ideal location to study the High Cascade-Western Cascade boundary due to the northwesterly trend of the streams across the transition zone.

The boundary between the two provinces (Western Cascades and High (ascades) is fault-controlled in other parts of the Cascade Range (see Figure 1.2). In the McKenzie River area, two north-south fault zones have been identified. The more easterly of the two fault zones is the Horse Creek-McKenzie River fault zone (Taylor, 1973, 1981; Brown and others, 1980a; Avramenko, 1981; Flaherty, 1981; Priest and others, 1983). This structure is estimated to have experienced $620 \mathrm{~m}$ of normal (down-to-theeast) displacement (Flaherty, 1981) about 4 Ma (see Priest and others, 1983, for discussion of this date) and constitutes the western boundary of a graben (Smith and Taylor, 1983; Priest and others, 1983). The Horse CreekMcKenzie River structure is approximately coincident with the Western Cascade-High Cascade boundary in the McKenzie River area.

Other north-south, down-to-the-east, faults have been mapped at the Western Cascade-High Cascade boundary in other areas of the Oregon Cascade Range. Barnes (1978) inferred a fault along the western side of Diamond Lake near Mt. Thielson. Both Hardiman (unpublished mapping) and Maynard (1974) inferred a fault at Lake of the Woods also with down-to-the-east displacement. Mapping by Smith and 
others (1982) showed north-south structure with down to the east displacement $15 \mathrm{~km}$ south-southwest of Crater Lake and extending southward for $20 \mathrm{~km}$ before swinging to a southeasterly trend. Several north-trending faults with down-to-the-east displacement are shown on mapping in the Breitenbush area by White (1980) that may be related to High Cascades province-bounding structures. However other workers in the same area (Hammond and others, 1982; Rollins, 1976) did not find these faults.

\section{Eugene-Denio Lineament}

Another focus of this study is an investigation into the nature of the Eugene-Denio lineament in the Willamette Pass area (Figures 1.1 and 1.2). The Eugene-Denio lineament was identified by Lawrence (1976) as a zone of right-lateral displacement that is one of the northern terminating structures of the Basin and Range Province. The northwesterly Eugene-Denio lineament passes through the study area along Hills and Salt Creeks (Figure 1.1; Lawrence, 1976; Kienle and others, 1981). Lawrence suggested that the axis of the Oregon High Cascades was offset 10-20 $\mathrm{km}$ across the lineament (Figure 1.2).

\section{$\underline{\text { Location }}$}

Willamette Pass is located approximately $75 \mathrm{~km}$ southeast of Eugene, Oregon. The nearest community is Oakridge, $10 \mathrm{~km}$ northwest of the study area. 
The most prominent topographic features of the study area are Wolf Mountain, Coyote Mountain, and Moss Mountain. Diamond Peak, east of and adjacent to the map area, dominates the topography. Diamond Peak is a Quaternary composite volcanic cone which has experienced substantial glaciation .

The principle streams in the area are, from north to south, Salt Creek, Hills and Pinto Creeks, Swift Creek, and the Middle Fork of the Willamette River. These streams have their sources in the High Cascades physiographic province and flow principally northwestward through deeply incised canyons within the study area.

Access to the area is by Oregon Highway 58 and a network of U.S. Forest Service maintained logging roads. The study area is principally under the administration of the Oakridge and Rigdon Ranger Districts of the Willamette National Forest, but there are several small land holdings by private wood products companies.

\section{Previous work}

Much of this study has been presented in Oregon Department of Geology and Mineral Industries Special Paper 15 (Priest and Vogt, 1983). Additional field work has been done by the author in the Willamette Pass area since the publication of that paper. A five kilometer strip along the west margin of this study, which received only last minute reconnaissance-level attention in Special Paper 15 
(in an effort to square off the study area), is here treated in more detail and, consequently, with major revisions. 
CHAPTER II

VOLCANIC STRATIGRAPHY

\section{Introduction}

Table 2.1 shows the stratigraphic columns of some Oregon Cascade workers. Table 2.2 summarizes the stratigraphy and lithology of the present study area. Informal local names are used to designate some of the map units in this study. No attempt is made to formalize the unit names. The geologic map of the Willamette Pass area is presented as Plate A, and a geologic cross-section (along $A-A^{\prime}$ of Plate A) is shown on Plate B.

Potassium-argon age dating has been used in this study to attempt to define the onset and end of volcanic episodes. Potassium-argon data, reproduced in Appendix II, were generated by Stan Evans of the University of Utah Research Institute. Locations of dated samples are shown on Plate A. A11 dated samples were collected and submitted to Evans by the author of this study.

Rock names will be assigned in the following manner, based on SiO2 weight percent after normalization to $100 \%$ volatile free:

$$
\begin{array}{ll}
\text { [Si02:] } & \text { [Rock name: ] } \\
<53 \% & \text { basalt }
\end{array}
$$




$\begin{array}{ll}53-57 \% & \text { basaltic andesite } \\ 57-63 \% & \text { andesite } \\ 63-70 \% & \text { dacite } \\ >70 \% & \text { rhyodacite }\end{array}$

This system is identical to that used in Priest and Vogt (1983). The divisions are the same as those used in the Basaltic Volcanism Study Project (1981). In those cases where an analysis is not available rock names are given based on phenocryst assemblage and, in some cases, textural characteristics. Ewart (1976, 1982) was able to show good correlation between phenocryst assemblage and SiO2 content. The term rhyodacite is preferentially chosen here instead of rhyolite to maintain consistency with the nomenclature of an earlier paper on this area (Woller and Black, 1983).

Oligocene-Miocene lavas, undifferentiated

The oldest rocks in the study area are the OligoceneMiocene lavas, undifferentiated. These rocks occur principally in the western portion of the study area, and also in the lower elevations of the Salt Creek drainage. Oligocene-Miocene lavas, undifferentiated, are equivalent to the Breitenbush formation of Hammond (1979), Hammond and others (1980), and White (1980), and the Little Butte Volcanic Series of Peck and others (1964; see Table 2.1). They are also equivalent to the Oligocene (?) volcanic rocks of Brown and others (1980b) and the tuffs of Cougar Reservoir of Priest and Woller (1983). They are included 


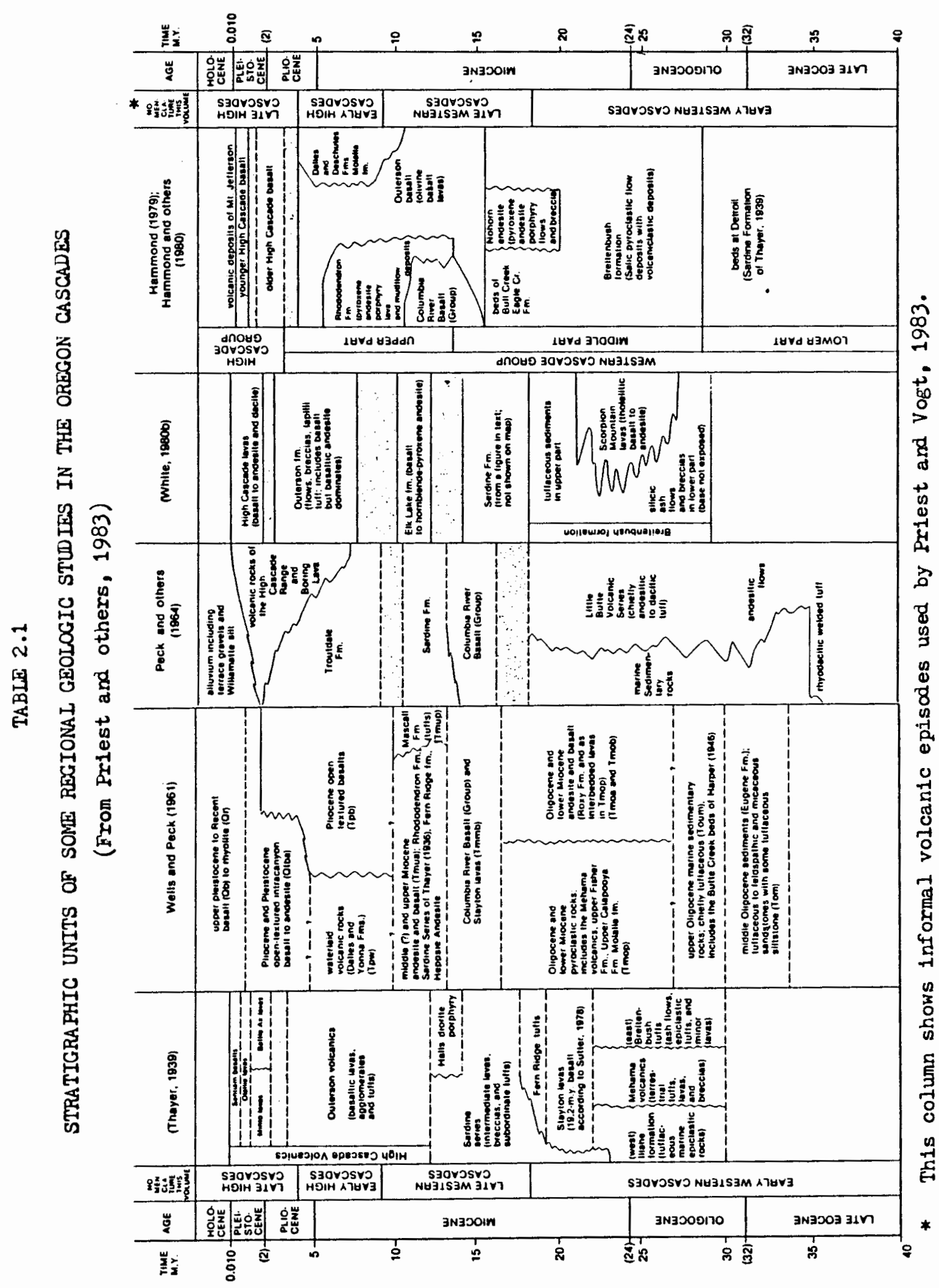


TABLE 2.2

STRATIGRAPHY OF THE WILLAMETTE PASS AREA.

\begin{tabular}{|c|c|c|c|c|}
\hline Map unit & $\begin{array}{l}\text { K-Ar dates } \\
(m . y . B . P .)\end{array}$ & $\begin{array}{l}\text { Maximum } \\
\text { exposed }\end{array}$ & $\begin{array}{l}\text { Si02 } \\
\text { range* }\end{array}$ & $\begin{array}{l}\text { Lithologic } \\
\text { description }\end{array}$ \\
\hline $\begin{array}{l}======== \pm=== \\
\text { Mazama } \\
\text { pumice-fal1 } \\
\text { deposit }\end{array}$ & $\begin{aligned}= & =====\pi===2 \\
& 6700 \\
\text { years } & *\end{aligned}$ & $\begin{array}{l}=x=m==2=x \\
3 \mathrm{~m}\end{array}$ & $\begin{aligned} &==x== \\
& 67.1\end{aligned}$ & $\begin{array}{l}===x=x=x======x=x \\
\text { Unconsolidated, } \\
\text { well-winnowed } \\
\text { pumice-fall; } \\
\text { yellow, voids } \\
\text { between clasts. } \\
\text { Appears bedded } \\
\text { where undisturbed. } \\
\text { Mantles topography. }\end{array}$ \\
\hline $\begin{array}{l}\text { Upper High } \\
\text { Cascade Lavas }\end{array}$ & $\begin{array}{l}\text { oldest: } \\
1.98 \\
\quad+/-0.25 \\
\text { youngest: } \\
0.17 \\
\quad+/-0.48\end{array}$ & $854 \mathrm{~m}$ & $\begin{array}{l}49.6- \\
57.7 \%\end{array}$ & $\begin{array}{l}\text { Olivine-bearing } \\
\text { basalts and } \\
\text { basaltic andesites } \\
\text { black to gray, } \\
\text { fresh, compact to } \\
\text { diktytaxitic, } \\
\text { undeformed. Unit } \\
\text { is intracanyon into } \\
\text { older topography. }\end{array}$ \\
\hline $\begin{array}{l}\text { Lower High } \\
\text { Cascade lavas }\end{array}$ & $\begin{array}{l}5.53 \\
+/-0.41 \\
5.56 \\
+/-0.34 \\
4.32 \\
+/-0.40\end{array}$ & $366 \mathrm{~m}$ & $\begin{array}{l}48.6- \\
52.9 \%\end{array}$ & $\begin{array}{l}\text { Olivine-bearing } \\
\text { basalts and } \\
\text { basaltic andesites, } \\
\text { compact, gray, } \\
\text { fresh. Caps } \\
\text { highest ridges of } \\
\text { Western Cascades } \\
\text { province. }\end{array}$ \\
\hline $\begin{array}{l}\text { Lavas of } \\
\text { Moss Mountain }\end{array}$ & $\begin{array}{l}17.3 \\
+/-0.8 \\
(?)\end{array}$ & $732 \mathrm{~m}$ & $\begin{array}{l}53.8- \\
62.4 \%\end{array}$ & $\begin{array}{l}\text { Pyroxene andesites, } \\
\text { dacites, and } \\
\text { basaltic andesites, } \\
\text { black to gray, } \\
\text { plagioclase phyric. }\end{array}$ \\
\hline $\begin{array}{l}\text { Lavas of } \\
\text { Tumblebug } \\
\text { Creek }\end{array}$ & $\begin{array}{l}\text { youngest: } \\
13.1 \\
\quad+/-0.6 \\
\text { o1dest: } \\
17.0 \\
+/-0.9\end{array}$ & $915 \mathrm{~m}$ & $\begin{array}{l}51.9- \\
55.8 \%\end{array}$ & $\begin{array}{l}\text { 0livine-bearing } \\
\text { basaltic andesites } \\
\text { and basalts, } \\
\text { fresh to weathered, } \\
\text { dark gray to gray, } \\
\text { generally compact. }\end{array}$ \\
\hline
\end{tabular}

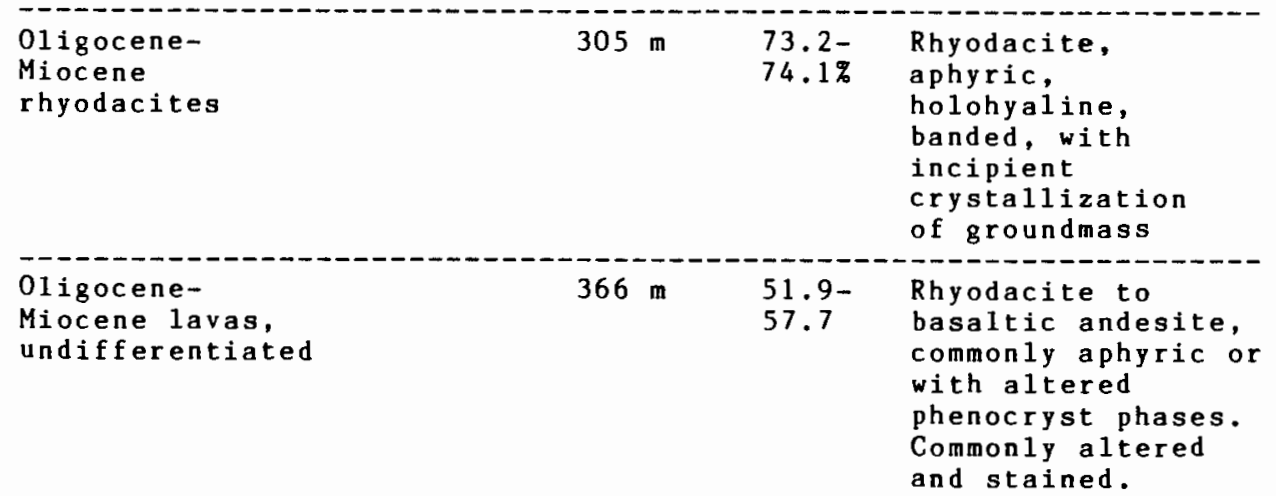

* calculated to $100 \%$ water free, with all iron as Fe0*.
* from Bacon (1983). 
in the early Western Cascade episode of volcanism of Priest and others (1983).

Oligocene-Miocene lavas, undifferentiated, are a very diverse unit, consisting of numerous ashflows, lavas and interbedded sediments. Ash-flow tuffs are probably the most common lithology, but due to their poor competency and proclivity to mass wasting, these units are usually only visible in road or railway cuts. The ash-flow tuffs commonly bear a high percentage of lithic fragments and occur in many colors, including green, yellow, beige and gray. Both welded and non-welded varieties are present. The occurrence of fragments of silicified wood, in some cases in the form of large branches, in the flows at Shady Gap indicates a subaerial origin. No vents for these pyroclastic units were identified within the study area. The lava flows of this unit range from rhyodacite to basaltic andesite. Common phenocrysts of these flows are quartz, plagioclase, hornblende, and hypersthene, although the mafic phases are commonly completely altered to phyllosilicate phases (smectites, saponites, and chlorites).

The Oligocene-Miocene lavas, undifferentiated, have been subjected to very low-grade alteration. Petrographic examination indicates the alteration generally consists of the appearance of chlorite, saponite, and/or smectite in groundmass and phenocryst phases. Hydrothermal alteration is sometimes indicated by fracture and cavity fillings of 
quartz, calcite, and zeolites. Pervasive green discoloration is present locally. Similar alteration appears to occur over wide areas of the Western Cascade Range.

The base of the 01igocene-Miocene lavas, undifferentiated, is not exposed in the study area. The equivalent Little Butte Volcanic Series of Peck and others (1964) is approximately $4600 \mathrm{~m}$ thick in the Umpqua River vicinity, south of the study area. Therefore only the top of this sequence is exposed in the Willamette Pass area. An unconformity occurs at the top of the Oligocene-Miocene lavas, undifferentiated.

No samples of this unit have been dated for this study, but the age of an equivalent unit from the Lookout Point area was determined to be $24.7+/-2.0$ Ma (Woller and Priest, 1983). An intrusive plug at Stone Mountain, west of the study area, was dated at $18.7+/-0.9$ Ma (Brown and others, 1980b). Both of those samples were altered.

An overlying unit within the study area, the lavas of Tumblebug Creek, was dated in its lower part as $17.0+1-$ $0.9 \mathrm{Ma}$ (this study), and constraining the upper age of the Oligocene-Miocene lavas, undifferentiated. The unconformity above 01igocene-Miocene lavas, undifferentiated, and the relative lack of alteration in the overlying map units also helps to constrain the end of this episode of Cascade volcanism. 
Oligocene-Miocene rhyodacites

The 0ligocene-Miocene rhyodacites crop out on the south-facing hillside between Mt. David Douglas and Fuji Meadow, in the Salt Creek drainage. These flows are equivalent to the upper part of the 0ligocene-Miocene lavas, undifferentiated, and some flows very similar to those elsewhere mapped as 01igocene-Miocene lavas, undifferentiated, are interbedded with 01igocene-Miocene rhyodacite flows. This unit is considered as an interbed within the thicker and more widespread Oligocene-Miocene lavas, undifferentiated.

These flows are aphanitic to glassy obsidian, and all are aphyric. Minor devitrification is sometimes present in the glass. The flows of this unit vary in color-buff, black, pink, white, and banded varieties were encountered.

The unit may be as much as $305 \mathrm{~m}$ thick, but an accurate determination is difficult to make due to an obscured lower boundary which results from the effects of landslides, colluvium, very thick vegetation, and remnants of much younger flows pasted against the hillside where this unit crops out.

Lavas of Tumblebug Creek

The lavas of Tumblebug Creek overlie the 01igoceneMiocene lavas, undifferentiated. These flows are primarily olivine-bearing basaltic andesites and basa1ts, which are medium to dark gray and compact to vesicular. Some 
slightly diktytaxitic flows occur in the Tumblebug Creek area. These rocks also occur on lower Coyote Mountain, on Jupiter Ridge, and lower Bear Mountain. Associated pyroclastic units, including ashflows, lahars and surge deposits, occur in the Baboon and Moss Creek area and also at Bear Mountain.

Several flows were dated for this study. One of the lowest flows on the south flank of Bear Mountain was dated at $17.0+/-0.9 \mathrm{Ma}$. (map sample number $15 ;$ locations of dated flows are shown by a solid triangle on Plate A.) A flow located near the top of the unit on Jupiter Ridge (map sample number 20) was dated at $13.1 \mathrm{t} /-0.6 \mathrm{Ma}$, and another lower in the section but in the same vicinity (map sample number 19) was dated at $13.5+/-1.1$ Ma. Other dates obtained on this unit were $14.1+/-0.8 \mathrm{Ma}$ and $15.6+/-0.6$ Ma (map sample numbers 21 and 13 , respectively). The 14.1 $+/-0.8 \mathrm{Ma}$ date was obtained on a basalt very low in the exposed section at Tumblebug Creek (at the southern margin of the study area) that is probably older than the flow dated on lower Bear Mountain. It has undergone some alteration (saponite + chlorite). The author's belief that this date is inaccurate is supported by the $15.6+/-0.6 \mathrm{Ma}$ obtained on a fresh flow stratigraphically above the flow that has the anomalous date. This date (15.6 Ma) appears consistent with all the other dates obtained on the unit. The lavas of Tumblebug Creek are stratigraphically equivalent to the Sardine Formation of Peck and others 
(1964), the Sardine Formation of White (1980), and the Outerson basalt of Hammond (1979) and Hammond and others (1980; Table 2.1). These flows are lithologically similar to the lavas of Outerson Mountain of Priest and Woller (1983). They are included in the late Western Cascade episode of volcanism of Priest and others (1983).

Vents for this unit are located at Tumblebug Creek (extreme southern margin of the study area) and at Jupiter Ridge. Other vents were probably present as well based on the widespread outcrop area of this unit.

\section{Lavas of Moss Mountain}

The lavas of Moss Mountain are commonly phyric, two pyroxene-bearing andesites. Plagioclase is the most common phenocryst phase, ranging from 5\% to 40\%. At Moss Mountain the unit grades from two-pyroxene andesite at the bottom of the exposed sequence to olivine-augite basaltic andesite near the top.

These lavas directly overlie the OligoceneMiocene lavas, undifferentiated, and the Oligocene-Miocene rhyodacites in the northern half of the study area. They also onlap the lavas of Tumblebug Creek in the Jupiter Ridge area. The unit thins to the south and to the west. It is thickest in the Moss Mountain area where it is in excess of $732 \mathrm{~m}$ thick.

Volcanic centers for the lavas of Moss Mountain are 
located at Mt. David Douglas and the north slope of Moss Mountain.

A flow from upper Moss Mountain (map sample number 30) was dated at $17.3+/-0.8 \mathrm{Ma}$. However the flow stratigraphically overlies two flows with younger K-Ar ages $(13.1+/-0.6,13.5+/-1.1 \mathrm{Ma})$ belonging to lavas of Tumblebug Creek. This suggests that the date for Moss Mountain may not be the true age of that flow. An alternative hypothesis is that the age dates of the two basaltic lavas are in error, which in turn would suggest that 3 other dates on lavas of Tumblebug Creek would be erroneous. The dates obtained for the lavas of Tumblebug Creek are consistent with the beginning of andesitic to basaltic volcanism (Priest and others, 1983) and also generally consistent with each other. Since the lavas of Moss Mountain overlie the lavas of Tumblebug Creek, the author feels the $17.3+/-0.8 \mathrm{Ma}$ age for the upper part of Moss Mountain is the inaccurate date.

The lavas of Moss Mountain therefore are stratigraphically equivalent to the Rhododendron Formation and Outerson basalt of Hammond (1979) and Hammond and others (1980), the Sardine Formation of Peck and others (1964), and the Sardine Formation and Elk Lake formation of White (1980). They belong to the late Western Cascade episode of volcanism of Priest and others (1983). The lavas of Moss Mountain are similar in age and lithology to andesitic lavas mapped at Lookout Point (the Miocene 
andesitic lavas of Woller and Priest, 1983) and at Cougar Reservoir (the andesites of Walker Creek of Priest and Woller, 1983).

\section{High Cascade lavas}

The High Cascade lavas are predominantly olivinebearing basalts, basaltic andesites, and low silica andesites. They are fresh, medium to dark gray, and compact to open textured. They are most common in the eastern half of the study area.

The High Cascade lavas are collectively equivalent to the volcanic rocks of the High Cascade Range and Boring Lavas of Peck and others (1964). The High Cascade lavas are here subdivided into the lower and upper High Cascade lavas. The distinction between the two units is based on stratigraphic position relative to an unconformity present in the study area and recognized in other areas of the Western Cascade Range (e.g., Priest and others, 1983; Woller and Priest, 1983; Hammond and others, 1980). The lower High Cascade lavas are preserved capping the ridges, topographically reversed from their primary depositional setting. The younger flows of the High Cascade lavas are intracanyon into the present topography. An uplift event occurred during the volcanic episode which produced the High Cascade lavas. Assignment of flows to their map unit in the study area therefore depends in large part on the recognition of their field relationships, i.e., their 
stratigraphic position relative to the unconformity. As discussed below and by Priest and others (1983), the uplift of the Western Cascades began about $4 \mathrm{Ma}$.

The distinction between lower and upper High Cascade lavas is useful primarily in the Western Cascades physiographic province, which has experienced substantial uplift and subsequent incision. The study area, however, extends into the High Cascades physiographic province in its easternmost part. The unconformity which serves to divide the lower and upper High Cascade lavas in the Western Cascades physiographic province is difficult to distinguish, if it exists at a11, in the High Cascades province. The unconformity unay be hidden by young lavas (equivalent to the upper High Cascade lavas) that have created the constructional volcanic platform of the High Cascade Range. In the High Cascade province, most upper High Cascade lavas overlie (conformably?) lower High Cascade lavas. Other obscuring factors include thick vegetation, relatively low relief, and the petrologic similarity of the two units. Therefore, in some areas of the map, sequences of High Cascade lavas that cannot be definitely assigned to either the lower or upper High Cascade lavas are mapped as the High Cascade lavas (undifferentiated). 
Lower High Cascade lavas

Lower High Cascade lavas cap many of the ridges of the Western Cascade province. Three K-Ar dates were obtained on the flows of this unit. A flow near Hemlock Butte (map number 34 ) that directly overlies lavas of Moss Mountain was dated at $5.56+/-0.34 \mathrm{Ma}$. This date may represent the onset of High Cascade volcanism in the Willamette Pass area. A similar date, $5.53+/-0.41 \mathrm{Ma}$, was obtained near the top of a lower High Cascade sequence near Pinto Mountain (map sample number 34 ). The third date $(4.32+1-$ $0.4 \mathrm{Ma}$ ) is from near the top of the sequence of lower High Cascade lavas at Bear Mountain (map sample number 31 ). This date is significant in that it is the youngest obtained for stratigraphically equivalent lavas in the Oregon Western Cascade Range. It suggests that the uplift and dissection of the Western Cascade Range occurred after 4.32 Ma.

Lower High Cascade lavas are equivalent to the older High Cascade basalt of Hammond (1979) and Hammond and others (1980), the Outerson formation of White (1980) and Taylor (1981), and to the lower part of the volcanic rocks of the High Cascade Range and Boring Lava of Peck and others (1964; see Tabie 2.1). They are also equivalent to the Miocene Pliocene basaltic lavas of Woller and Black (1983) and the lavas of Tipsoo Butte of Priest and Woller (1983). They were erupted during the early High Cascade volcanic episode of Priest and others (1983). 
Vent areas for these lavas occur at several places in the study area, including Bear Mountain and Wolf Mountain (Figure 1.1; Plate A).

\section{Upper High Cascade lavas}

Upper High Cascade lavas are stratigraphically equivalent to the High Cascade lavas of White (1980) and the older and younger High Cascade basalts and volcanic deposits of Mount Jefferson of Hammond and others (1980). They are equivalent to the upper part of the volcanic rocks of the High Cascade Range and Boring Lava of Peck and others (1964). They were erupted during the late High Cascade volcanic episode of Priest and others (1983).

These flows of predominanty basaltic and basaltic andesite composition commonly flowed through canyons cut into the older units in most of the map area. They are present in almost all the major drainages. Some of these lavas are pasted high up on the canyon walls, where they were deposited during the early stages of downcutting of the streams. As the streams incised further into the topography these lavas became remnant markers of an earlier stream base level. As volcanism continued, younger lavas occupied the lowest levels of the valleys, in turn to be abandoned in the side walls of the canyons. The very youngest lavas of this sequence occupy the present day stream beds. Young intracanyon lavas form Salt Creek Falls and the valley floors of upper Pinto and Emigrant Creeks. 
It should be possible to gage the timing of Western Cascade uplift and downcutting with a K-Ar dating program of intracanyon upper High Cascade lavas in Salt Creek. Upper High Cascade lavas also occur draped over canyon walls in some locations (e.g. upper Salt Creek).

The youngest $\mathrm{K}-\mathrm{Ar}$ date acquired for this study, 0.17 $+/-0.48 \mathrm{Ma}$, was obtained on a sample of a flow from the upper Willamette River valley (map sample number 39). It is below the range for which the laboratory results can be considered reliable (Stan Evans, personal communication, 1982). The flow morphology and geomorphic occurrence of some of the upper High Cascade lavas indicate that some are considerably younger than 100,000 years, a1though there is no evidence that any of these lavas is younger than the last glaciation (13,500-15,000 years; Long and Leverton, $1984)$

The oldest date on these lavas in the study area was obtained on an intracanyon flow located near the confluence of Wolf and Pinto Creeks, at an elevation of approximately 4700 feet $(1450 \mathrm{~m})$. The flow is, at the sampled location, about $250 \mathrm{~m}$ above Pinto Creek. The date on this intracanyon flow places constraints on the minimum age for the onset of downcutting of the streams of the Willamette Pass area after/during the the uplift of the Western Cascades.

Vents for the upper High Cascade lavas are present near Salt Creek Falls and at Diamond Peak, Mt. Yoran, and 
Fuji Mountain (the latter all located immediately east of the study area; see Figure 2.1 and Plate A). Most of these lavas, therefore, originated east of the study area, in the Diamond Peak and Waldo Lake Wilderness areas.

\section{Mazama pumice-fall deposit}

The youngest volcanic unit exposed in the study area is a thin dacitic air-fall tuff that originated in the cataclysmic eruption of Mt. Mazama (Crater Lake) about 7000 year B.P. (Bacon, 1983). It mantles the landscape in thicknesses up to 2 meters. Its presence is usually not visibly evident due to the thick vegetation and to redistribution resulting from abundant seasonal runoff.

The Mazama pumice-fall deposit is yellow and unconsolidated, and appears bedded where undisturbed. It is composed of lapilli to coarse ash-sized pumice. Voids occupy the interstices between pumice particles. No fine ash- or block-sized fragments are present. 


\section{CHAPTER III}

\section{STRUCTURE}

\section{Introduction}

Woller and Black (1983) suggested that north-south faults occurred in the Groundhog Creek and in the upper Salt Creek area, although evidence was not compelling for either structure. In the light of additional field work by the author, each of these areas will be reevaluated below.

\section{Discussion of the Groundhog Creek lineation}

A north-south 1 ineament is formed by Groundhog Creek as it flows northward into Hills Creek in the western portion of the study area (see Plate A). The lineation continues northward across Hills Creek, through Shady Gap, continuing through McCredie Hot. Springs (on Salt Creek) to Bunchgrass Ridge at the north margin of the study area. Extensive landslides are present along the lineament (Plate A).

The lineament is almost colinear with a trough of low residual gravity described by Couch and others (1982a; 1982b). Couch and others (1982a) reported that this 1inear low residual gravity anomaly represents a large fracture and fault zone of regional extent and probably represents the western margin of a High Cascade graben. 
West of the Groundhog Creek lineament the OligoceneMiocene lavas, undifferentiated, is the major rock unit present. The sequence is particularly well exposed in roadcuts on the lower and middle flanks of Kitson Ridge, the ridge between Hills Creek and Salt Creek immediately west of the study area (Figure 1.1). It dips to the eastnortheast about 15 degrees, and is composed of numerous epiclastic and pyroclastic units with some interbedded lava flows. The lavas of Tumblebug Creek are present west of the lineament at Squaw Butte and west of Juniper Ridge (Figure 2.1) capping the ridges.

East of the lineament the dominant rock units are the lavas of Tumblebug Creek and lavas of Moss Mountain. The contacts between these two units and between the lavas of Tumblebug Creek and the underlying Oligocene-Miocene Iavas, undifferentiated, dip eastward (Plate B). Attitudes measured within the lavas of Tumblebug Creek commonly vary widely, but the majority dip northeasterly around 20 degrees. Therefore it is possible that the presence of a homoclinal or monoclinal fold may contribute to the northsouth lineament.

Faulting does not affect middle Miocene flow units (i.e., the lavas of Tumblebug Creek and lavas of Moss Mountain). The case is less clear in the older rock units (i.e., the Oligocene-Miocene lavas, undifferentiated), in which no individual flow unit could be correlated crossing 
the lineament. There is, however, no evidence of major displacement in these units, although exposure is limited.

The presence of McCredie Hot Springs issuing from young stream gravels at the intersection of the Groundhog Creek and Eugene-Denio lineaments suggests the possibility of local structural-induced permeability in the generally impermeable Oligocene-Miocene lavas, undifferentiated. Despite the supporting implication of the residual gravity anomaly, there is no evidence of structural deformation in any nearby outcrop of bedrock, although the local constraints on the northwesterly Eugene-Denio trend are poor. It is possible that buried structures may be responsible for both the thermal springs and the residual gravity anomaly.

An alternative hypothesis for the origin of the thermal springs would be that thermal waters are migrating from the east along a permeable flow unit. As stated earlier, there is some evidence that the regional dip is toward the east in this area. This hypothesis would explain the sharp transition zone between regions of high and low heat flow (Black and others, 1983; Blackwell and others, 1982). It is also possible that lateral convective flow may be locally channeled by an unseen fracture to the surface. These hypotheses will be examined in more detail in the next chapter. 
A discussion of possible structure in the upper Salt Creek

area

Woller and Black (1983) inferred a fault along the west side of Waldo Lake based on stratigraphic, geomorphic, and geophysical indications. They noted that 1) young High Cascade lavas appear to abut against the west side of a north-south high of Tertiary volcanics, 2) the presence of Waldo Lake cannot be attributed to glaciation, and 3) a west to east, 6-8 mgal increase in the residual gravity across the western margin of Waldo Lake extends northward into the Horse Creek-McKenzie River area where faulting has been mapped by many workers (Brown and others, 1980a; Taylor, 1981; Flaherty, 1981; Avramenko, 1981). The Waldo Lake structure was probably active around $4 \mathrm{Ma}$, and may be related to the uplift of the Western Cascades.

The author is not able to prove the inferred structure extends into upper Salt Creek even though many of the same stratigraphic and geophysical characteristics are present as in the Waldo Lake area. An extension of the inferred fault into the upper Salt Creek area would approximate the boundary between the predominantly Tertiary terrane on the west and young Quaternary volcanic deposits and volcanoes on the east, as it does in the Waldo Lake area. Low relief, abundant vegetation, and the presence of young lavas make it difficult to prove the existence of a structure in the upper Salt Creek area. 
The residual gravity anomaly discussed above continues southward through the upper Salt Creek area (See Figure 4.1). The cause of the anomaly may be the presence of a layer of infilling flows (upper High Cascade lavas) above a down-dropped block. The extension of this anomaly northward into the Horse Creek-McKenzie River fault zone (Figure 1.2) is support for this model.

The anomaly may also be caused by the presence of high level intrusions beneath the High Cascade province. In many parts of the Oregon High Cascades, prominent northsouth lineations of volcanic vents suggest these vents occur along north-south dike systems. Alternatively, the elevated isotherms of the High Cascades (e.g., Blackwell and others, 1982) suggest relatively shallow zones of partial melting. In this environment it would not be hard to envision partially melted bodies of pluton (batholithic?) size in a north-south orientation under the High Cascade Range. However, teleseismic studies have not been able to detect shallow large magma chambers under historically active High Cascades stratocones (Weaver and others, 1982; Stauber and Berge, 1985; Berge, personal communication to H. M. Iyer, cited in Iyer, 1985).

\section{Northwest-trending structures}

Discussion of the Eugene-Denio lineament

The Eugene-Denio 1ineament (Lawrence, 1976; Kienle and others, 1981; Figures 1.1 and 1.2) passes through the study 
area on a northwest trend along Hills and Salt Creeks. Lawrence (1976) and Kienle and others (1981) suggested that the lineament was a fault and fracture zone that accommodated east-west extension in the Basin and Range province. Lawrence (1976) suggested that the High Cascade axis, as defined by the major High Cascade stratocones, was displaced in a right-1ateral sense $10-20 \mathrm{~km}$ across the lineament.

Woller and Priest (1983) showed that there is no right-lateral displacement on a 22 Ma intracanyon sequence of tholeitic lavas that crosses the lineament at Lookout Point, $7 \mathrm{~km}$ northwest of Oakridge (Figure 1.1).

No evidence was found in the study area of northwest faulting along the Eugene-Denio lineament. The argument that the High Cascade axis is offset (Lawrence, 1976) is predicated on the premises that a) the alignment of the High Cascade stratovolcanoes marks the axis of the High Cascade Range and b) that the margins of the High Cascade Range were sufficiently well known to make that argument. Plate A shows that the base of Diamond Peak consists of a thick section of exposed Tertiary rocks, and is situated near the Western Cascades - High Cascades boundary. Therefore, according to the previously discussed stratigraphic and topographic characteristics of the Western Cascade and High Cascade Ranges, Diamond Peak is located within the Western Cascade Range. Other youthful volcanic vents located within the Western Cascades include: 
Snow Peak (Peck and others, 1964), Armet Creek (Woller and Priest, 1983), Batt1e Ax (White, 1980b), and the vent for the High Prairie flow (Macleod, personal communication, 1982)).

Other northwest-trending structures

Other northwesterly faults and shears appear to be minor features principally related to nearby volcanic vents (e.g., near the Tumblebug Creek vent and on lower Bear Mountain). No major displacements were noted on these features.

\section{Northeast-trending structures}

A northeast-trending fault zone extends from the Hemlock Butte area to Salt Creek, crossing the intervening ridge at Pinto Mountain. At Pinto Mountain, where lower High Cascade lavas are juxtaposed against lavas of Moss Mountain, an estimated $150 \mathrm{~m}$ of displacement is present on the lower contact of the High Cascade lavas. The sense of the fault is normal, with the southeast side displaced downwards relative to the northwest side of the fault.

The fault is well-exposed along Highway 58 in the Salt Creek drainage, although the displacement appears to be distributed in at least two zones of displacement.

The fault zone disappears northeastward under a cover of High Cascade lavas near Fuji Meadow. Southwestward, the fault zone disappears under glacial drift near Hemlock Butte. It is unclear if the structure continues 
southwestward along Swift Creek, which flows on an almost colinear course southwestward from this location.

Alteration is present along the fault in many places. Northeast of Hemlock Butte rocks in the zone (lavas of Moss Mountain) are bleached, brecciated, and silicified. Disseminated pyrite is also present. The lavas of Moss Mountain have undergone much more extensive alteration than the nearby lower High Cascade lavas. The latter rocks only show alteration in the olivine phenocrysts and interstitial groundmass phases, where saponite and minor chlorite are the alteration minerals. 
CHAPTER IV

\section{GEOPHYSICS}

The Cascade Range is part of the nearly continuous band of subduction zones and associated volcanic arcs that surround the Pacific basin (the "ring of fire"). The Cascade Range is believed to be the volcanic arc associated with the subduction of the Juan de Fuca plate beneath the North American plate (Atwater, 1970; Wells and others, 1984). Evidence of Recent, if not active, subduction of the Juan de Fuca plate was reviewed by Drake (1982) and includes 1) young calcalkaline volcanic activity in the High Cascade Range (e.g., Santiam Pass, the Three Sisters vicinity, Mt. Mazama), 2) compressional deformation of young sediments at the base of the continental slope off the Oregon coast (Byrne and others, 1966), 3) micropaleontological and sedimentological evidence that indicates substantial uplift of the continental slope with respect to the original depositional environment (e.g., Byrne and others, 1966; von Huene and Kulm, 1973), 4) the heat flow patterns of Western Oregon and Washington are typical of volcanic arcs (Blackwell and others, 1982). Geophysical research in the Cascade Range has been stimulated by interest in the potential geothermal 
resources of the arc. As a result, the Cascade Range, and the central Oregon Cascades in particular, has been the subject of a suite of geophysical studies. In order to discuss the geothermal resources of the Willamette Pass area, some of the geophysical studies of the central oregon Cascade Range will be reviewed.

\section{Gravity}

Regional Bouguer and free air anomaly modeling indicates that the continental crust is $35 \mathrm{~km}$ thick under the northern High Cascade Range and 40-50 km under the southern High Cascade Range. The continental crust "shoals" rapidly to the west under the Western Cascades and Willamette Valley (Thirukaval and others, 1970; Couch and others, 1982a). The continental crust is a similar or slightly thinner thickness to the east (Thirukaval and others, 1970; Couch and others, 1982a). These interpretations are consistent with the tectonic and petrologic interpretation of the Cascade Range as a volcanic arc of a continental margin.

Couch and others (1982a) and Pitts (1979) identified a nearly contiguous set of (residual) gravimetric lows that trends north-northeast through much of the central oregon Cascade Range (Figure 4.1). This gravity "trough" was interpreted as a fracture or fault system, with possible vertical displacements of up to $3 \mathrm{~km}$. The gravity trough is located at the western margin of the study area, along 


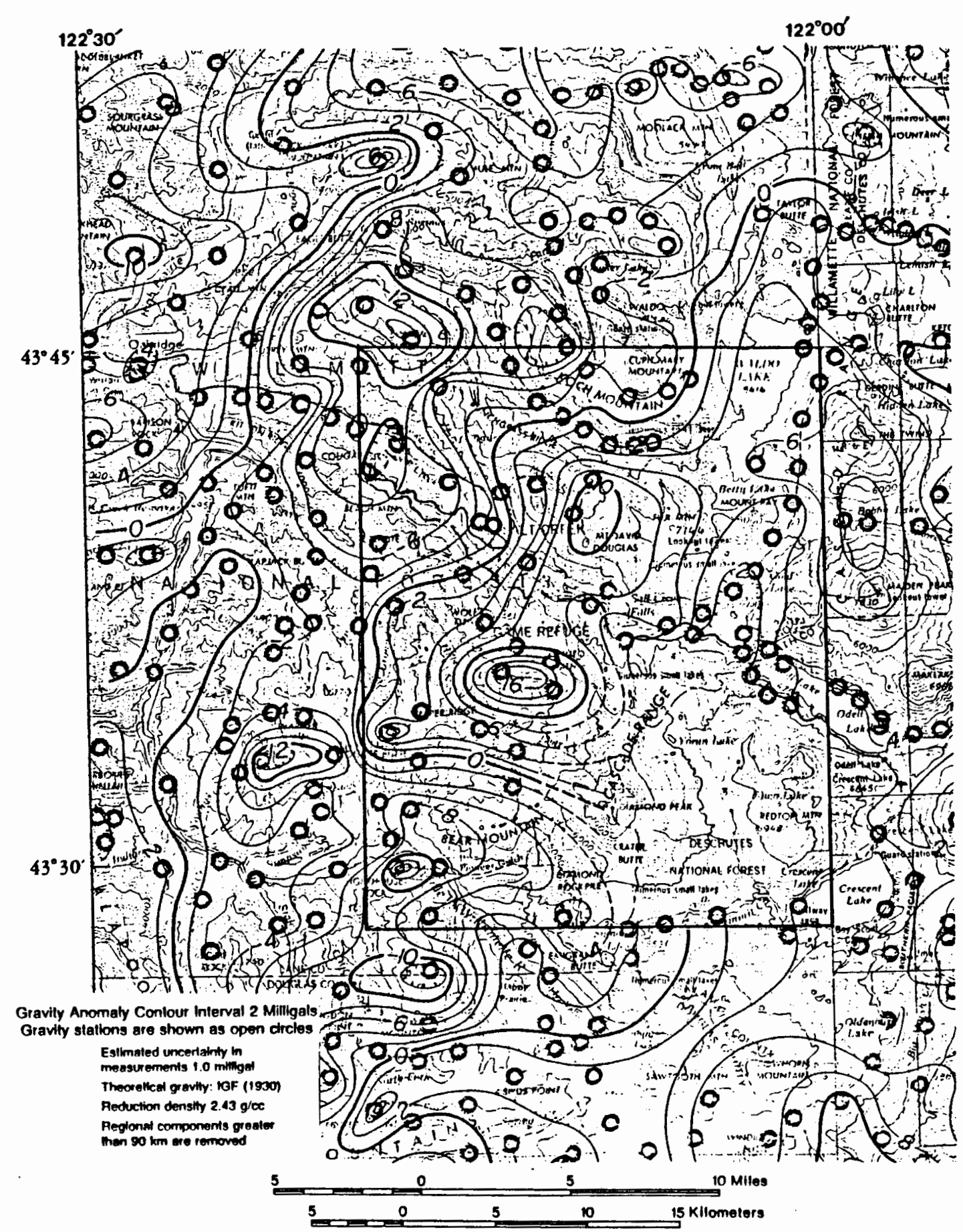

Flgure 4.1. Residual gravity of the Willamette Pass area; Rectangle shows area of Plate A. (Sources Couch and others, 1982b.) 
the north-south 1 ineament of Groundhog Creek. Farther north, the north-south Iineament and fault at Cougar Reservoir (Priest and Woller, 1983) are associated with the gravity anomaly. Still farther north, the trough may be associated with another fault zone near Breitenbush Hot Springs (G.R. Priest, persona1 communication, 1984). Couch and others (1982a) believe that the trough coincides with the physiographic boundary between the Western Cascades and the High Cascades, but the usage of "High Cascades" in that paper includes that part of the Western Cascades that is dominated by middle Miocene rocks (equivalent to the lavas of Moss Mountain and lavas of Tumblebug Creek).

South of Groundhog Creek the gravity trough swings to a southeasterly trend toward Crater Lake and the Klamath Lake graben (Couch and others, 1982a). It is unclear if the gravity anomaly is reflected in the surficial geology between Crater Lake and Groundhog Creek, due to a paucity of detailed mapping in this area.

Pitts (1979) and Couch (1979) inferred a left-latera1 structure along the Eugene-Denio trend from residual gravity studies. Field mapping does not substantiate lateral displacement along the lineament since the early Miocene (Woller and Priest, 1983; this study).

Woller and Black (1983) noted a residual gravity anomaly that coincides with the north-trending Horse Creek - McKenzie River fault zone (e.g., Flaherty, 1981; Brown and others, 1980a) and the fault inferred at Waldo Lake 
(Woller and Black, 1983) which may extend into the eastern portion of the study area described here (Figures 1.2 and 4.1). In the study area the anomaly has an amplitude of 68 mgals, with gravity increasing eastward.

\section{Seismic studies}

Virtually all of the recorded seismic activity in Oregon is shallow $(<70 \mathrm{~km})$, and little if any of the seismic activity is associated with the subduction of the Juan de Fuca plate beneath the Oregon Cascades (Couch and Lowel1, 1971). Some possible explanations for aseismic subduction are 1) the geologically youthful age of the subducting lithosphere suggests that the lithosphere is relatively warm, and therefore would be more conducive to plastic deformation (Atwater, 1970), 2) sediments with incorporated water may be subducted along with the oceanic lithosphere, and may have a lubricating effect on the movement of the subducted plate (Kulm, personal communication to Drake, cited in Drake, 1982) and 3) a combination of kinematic conditions, such as angle of dip and convergence angle, may affect the character of subduction (Furlong and others, 1982; Drake, 1982).

Seismic refraction studies have given researchers important information on crustal thickness and density. Leaver and others (1984) identified the upper mantle boundary at $44 \mathrm{~km}$ depth under the central Oregon Cascades. They also presented travel time profiles for the crust and 
upper mantle. They show velocities of $2.9-4.8 \mathrm{~km} / \mathrm{sec}$ to $3.4 \mathrm{~km} \mathrm{depth}, 6.0-7.1 \mathrm{~km} / \mathrm{sec}$ to $42 \mathrm{~km}$ depth (near the Moho), and $7.7-8.2 \mathrm{~km} / \mathrm{sec}$ in the upper mantle.

\section{Aeromagnetic studies}

Connard (1980) and Couch (1979) described the results of aeromagnetic survey studies in the central Oregon Cascade Range. These studies include depth to Curie point calculations for the study area. Their findings (with respect to the study area) are presented in Figure 4.2. The boundary of the region characterized by shallow Curie temperatures $(6-9 \mathrm{~km})$ approximately bisects the study area, between the Groundhog Creek lineament and gravity trough on the west, and the extension of the Waldo Lake fault (Woller and Black, 1983) south into the study area. All of the known thermal springs of the Willamette Pass area are situated outside of this zone (Figure 4.2).

\section{Heat flow and geothermal studies}

McCredie Hot Springs issue from alluvium and landslide debris along Salt Creek at a maximum recorded temperature of $73 \circ \mathrm{C}$. McCredie Hot Springs, along with nearby Kitson Hot Springs (west of the study area along Hills Creek) and Wall Creek warm springs (north of the study area; see Figure 4.2), are evidence of a geothermal resource in the Willamette Pass area. The area is designated a Known Geothermal Resource Area (KGRA) by the U.S. Department of the Interior. 


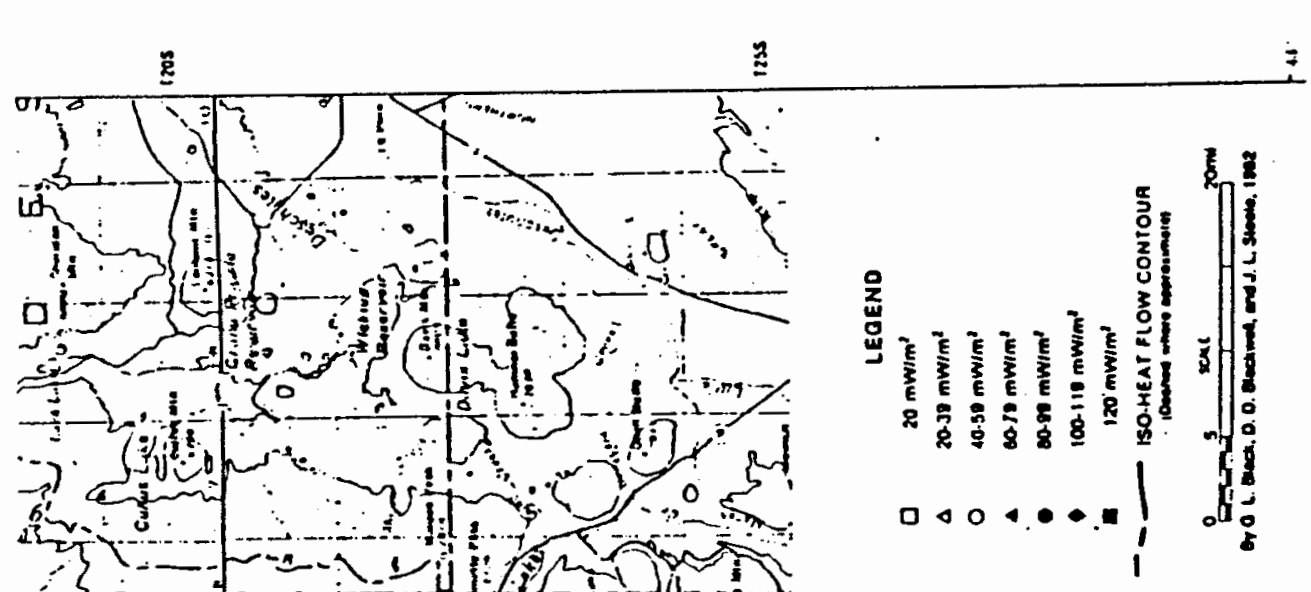

- ᄃ

is

苟式然品

उ

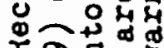

1. 은 - 젛당 प्ञ क 乱现

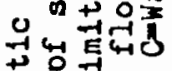
要

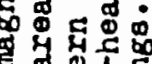
हुㅇํㅇ

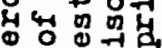
$x$ ⿰冫

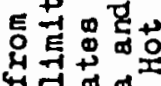
西出

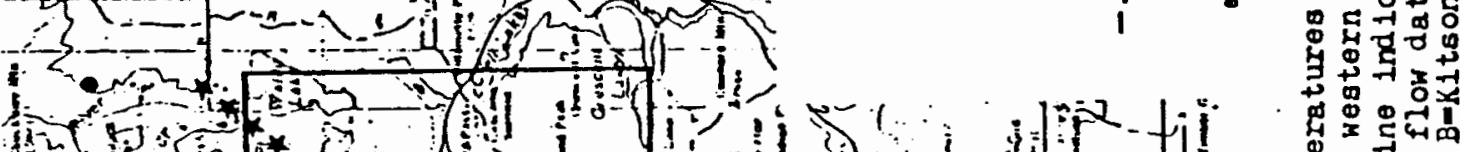

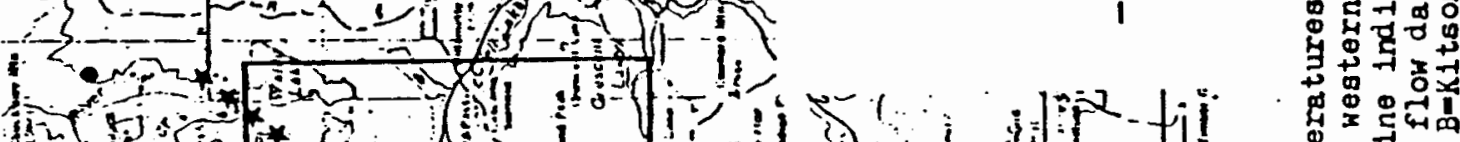
an

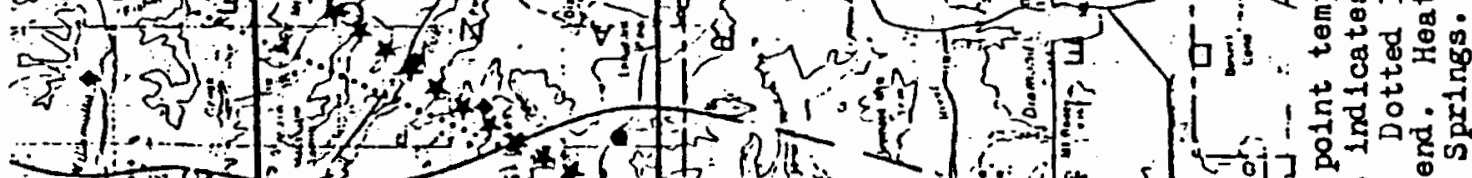
1

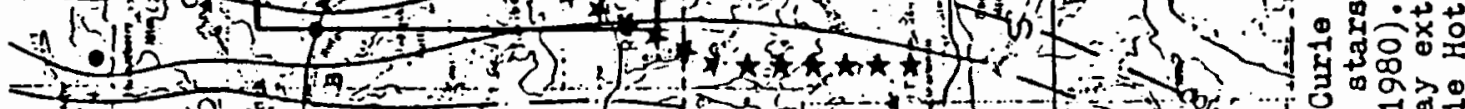
1 wa 24,0 , 3

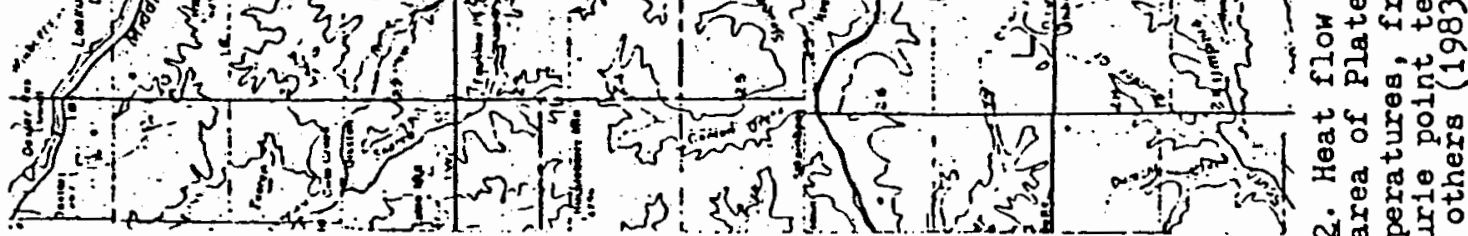

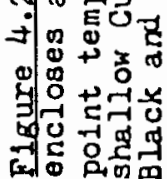


Spring chemistry and calculated reservoir temperatures for McCredie, Kitson, and Wall Creek thermal springs are presented in Table 4.1. A11 the springs are high in chloride ion and low in sulfate and bicarbonate, characteristics common to almost all the thermal springs of the Oregon Cascades (Mariner and others, 1980). The chemistry therefore suggests deep circulation, perhaps indicating reaction or origin in Eocene sediments at depth (Mariner and others, 1980). The silica and $\mathrm{Na}-\mathrm{K}-\mathrm{Ca}$ reservoir temperatures for McCredie Hot Springs indicate minimum reservoir temperatures of $114-124$ oC. 150 oC is considered necessary for generation of electric power.

Priest (1983) grouped the thermal springs of the Cascade Range into two north-south belts, the BagbyMcCredie belt (the more westerly) and the Austin-Belknap belt. The Bagby-McCredie belt (which includes Kitson and Wall Creek springs) has lower spring temperatures (and lower calculated reservoir temperatures) than the AustinBelknap belt. Within the area shown in Figure 4.2, the springs decrease in temperature and calculated reservoir temperature from east to west.

Heat flow in the Cascades has received considerable study from the Oregon Department of Geology and Mineral Industries and David Blackwell of Southern Methodist University (e.g., Blackwell and others, 1978; Blackwell and others, 1982; Black and others, 1983). This work has been stimulated not only by interest in the geothermal resource, 
TABLE 4.1

WATER CHEMISTRY AND CALCULATED RESERVOIR TEMPERATURES OF THERMAL SPRINGS IN THE WILlametTE PASS AREA

Al1 units in mg/ 1 unless otherwise noted. Sources are: Mariner and others (1980); Brown and others (1980); and Mariner (1985).

$$
\text { McCredie }
$$

Kitson

Hot Springs Hot Springs

Wa11 Cr warm springs

temperature ( $O C)$ :

$\mathrm{pH}$ :

conductance $(\mathrm{mho} / \mathrm{cm})$ :

alkalinity (mg/1 $\mathrm{CaCO} 3): 16$

SiO2:

$\mathrm{Ca}:$

$\mathrm{K}$ :

$\mathrm{Ca}$ :

$\mathrm{Mg}$ :

Li:

Fe (total):

A1 :

C1:

$\mathrm{F}$ :

P04:

S04:

NH 3 :

$\mathrm{B}$ :
73

7.3

44.4
7.4
10500
18
47
726
28
726
5.7
1.8
.01
.27
3420
2.8
.54
197
-
25

41.0
7.2 2340

35

62.7

130

10.8

130

460 .

0.9

1.40

.02

$2200^{.01}$

2.70

$240^{.61}$

.26

18.0
1

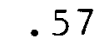

.05

602

4.1

$108^{.16}$

6.1

Chemical geothermometers ( $O C$ ):

$\begin{array}{lrrr}\text { SiO2 (conductive): } & 124 & 99 & 113 \\ \text { SiO2 (adiabatic): } & 122 & 100 & 112 \\ \text { SiO2 (cha1cedony): } & 96 & 69 & 84 \\ \text { SiO2 (opa1): } & 6 & -16 & -5 \\ \mathrm{Na}-\mathrm{K}: & 88 & 82 & 110 \\ \mathrm{Na}-\mathrm{K}-\mathrm{Ca}(1 / 3): & 114 & 81 & 125 \\ \mathrm{Na}-\mathrm{K}-\mathrm{Ca}(4 / 3): & 110 & - & 73 \\ \mathrm{Na}-\mathrm{K}-\mathrm{Ca} \text { (Mg corrected) } & 74 & - & - \\ \mathrm{S} 04-\mathrm{H} 2 \mathrm{O} & 118 & 134 & 160 \\ \text { Anhydrite* } & 130 & & -\end{array}$

"Ca-C1 component", as described in Mariner (1985). 
but also by the desire to understand volcanism and arc processes in the only active volcanic arc in the conterminous United States. The Oregon Cascade Range is one of the best studied volcanic arcs in the world with respect to heat flow (Blackwell and others, 1982). Many temperature gradient holes have been drilled in the mountain range for the specific purpose of studying the heat flow regime (Black and others, 1983). The author supervised the drilling and temperature-probing of many of these holes. Many "scrounge" (i.e., unsealed) wells were also probed.

Black and others (1983) and Blackwell and others (1982) have described a narrow heat flow transition zone between the low heat flow (approximately $40 \mathrm{~mW} / \mathrm{m} 2$ ) that characterizes the Willamette Valley and western Western Cascade Range and the high heat flow ( $>100 \mathrm{~mW} / \mathrm{m} 2)$ of the High Cascades and eastern Western Cascades (Figures 4.2, 1.2). The transition zone is about $20 \mathrm{~km}$ in width. These studies indicate the zone of high heat flow characterizes the entire Oregon High Cascade Range south of the Clackamas River lineament (Figure 1.2).

The heat flow data generally agrees with the elevated Curie point depth calculations of Connard (1980) and Couch (1979), but extend farther to the west in the study area (Figure 4.2). The $100 \mathrm{~mW} / \mathrm{m} 2$ contour is located along the Groundhog lineament and near McCredie Hot Springs (Black and others, 1983). Kitson Hot Springs and Wall Creek warm 
spring are also associated with the transition zone in the Willamette Pass area (Figure 4.2).

Black and others (1983) and Blackwell and others (1983) presented four models to explain the thermal springs and heat flow of the central Cascade Range. These models are discussed briefly below (Refer to Figure 4.3):

1) A shallow heat source at ( $7-10 \mathrm{~km})$ underlies the entire zone of high heat flow. The observed heat flow anomaly is thus essentially produced by conductive heat transfer. Subsurface circulation could be in roughly vertical cells. This is the favored model of Blackwell and others (1982). However, in most of the Western Cascade Range, there is little field evidence of shallow hot heat sources. There are relatively few High Cascade lavasequivalent dikes, plugs, and vents within the western portion of the heat flow anomaly, even though the east-west extensional environment in the late Tertiary and Quaternary is well documented. It should be noted, however, that there are vents for High Cascade-equivalent lavas in, and to the west of, the heat flow transition zone. The aeromagnetic studies of Connard (1980) described above could not sense shallow Curie point temperatures in the vicinity of the thermal springs. Furthermore, the 01igocene-Miocene lavas, undifferentiated, which are predominantly slightly altered tuffaceous units, are believed to underlie the Western Cascade Range to considerable depths and probably are a relatively 


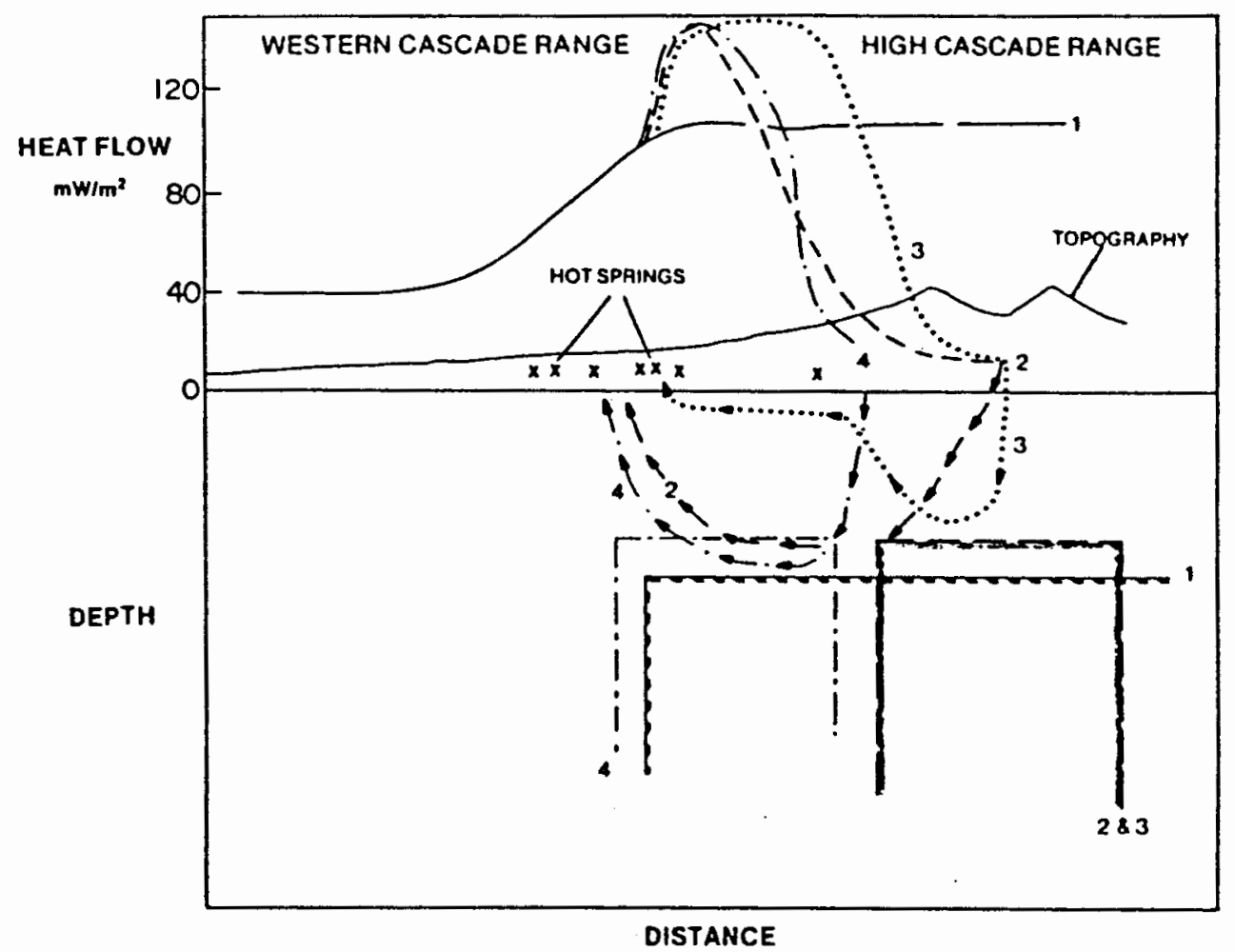

Flgure 4.3. Models showing possible origins of Cascade thermal springs and the heat flow anomaly. See text for explanation. (Sources: Blackwell and others, 1982; Black and others, 1983) 
impermeable unit to vertical circulation. Peck and others (1964) estimated this unit to be about $4500 \mathrm{~m}$ thick.

2) A shallow heat source underlies the High Cascade axis, and deep lateral circulation with ascent through fractures or other structures is responsible for the hot springs along the transition zone. In this model, the heat flow would be expected to be highest at the transition zone, and fall off rapidly to the east and west. Heat flow profiles, however, support a broader zone of high heat flow than suggested by this model. Also this model does not account for the lower temperatures of the Bagby-McCredie belt of springs compared to the Austin-Belknap belt.

3) As in model 2, the heat source underlies the High Cascade axis, but the convective cells are stratigraphica11y controlled at relatively shallow depths. Figure 4.3 shows that the heat flow anomaly is broader than in model 2, but may decrease under the High Cascade Range. Although there is some evidence of high heat flow at the western margin of the High Cascade Range (Youngquist, 1980), there is virtually no gradient or heat flow data for the axis of the High Cascades south of the Clackamas River 1ineament. (The heat flow anomaly described at Crater Lake by Williams and Von Herzen (1982) must be considered a spot anomaly above a youthful caldera, and heat flow data from the east side of the range does not constrain the interpretation of heat flow on the west side of the range.) This is due to the downward percolation of runoff through 
the porous High Cascade rocks of the High Cascade Range which hides the true regional gradient from shallow drilling exploration. Deep drilling in the region has been beset with drilling problems in the interflow zones in the young volcanics.

4) A shallow heat source underlies the transition zone and eastern portion of the Western Cascades. Thermal convective cycles are local and more or less vertical. This model fails to account for the voluminous Quaternary volcanism to the east of the shallow heat source and the relatively few young dikes and vents in the western portion of the heat flow anomaly in the study area. It also fails to account for the consistently lower temperatures of the Bagby-McCredie belt compared to the Austin-Belknap belt in areas to the north.

The location of McCredie Hot Springs projects stratigraphically into a lava flow in the upper part of the 0ligocene-Miocene lavas, undifferentiated. The lava flow could provide a permeable passageway for thermal waters, or, alternatively, the waters could be rising along a hidden fracture or fault zone.

Mapping by George Priest of Oregon Department of Geology and Mineral Industries suggests an analogous geologic environment in the Breitenbush Hot Springs area (G.R. Priest, personal communication, 1985, 1986). Those springs have their orifices at the lower contact of a distinctive lava flow within Hammond's (1979) Green Tuff of 
Cleator Bend member of the Breitenbush formation (G.R. Priest, personal communication, 1986). The host rocks are of a similar age and lithology as the Oligocene-Miocene lavas, undifferentiated, and have experienced deformation. Recent (1980) deep drilling by Sunedco $3.2 \mathrm{~km}$ southeast of Breitenbush Hot Springs area encountered the same flow unit at a depth of about $630 \mathrm{~m}$. The temperature profile of that hole is presented in Figure 4.4. The profile shows that a hot aquifer with a temperature of $1360 \mathrm{C}$ was encountered at 752-782 $\mathrm{m}$. Other temperature gradient surveys in the area indicate that the aquifer dips to the east where it may reach much higher temperatures (Waibel, in preparation, cited in Priest, 1985). Below $782 \mathrm{~m}$ in the Sunedco hole, the temperature profile exhibits a lower gradient, and comparison with the background regional temperature gradient of $60 \circ \mathrm{C} / \mathrm{km}$ (Blackwell and others, 1978, 1982; shown as dashed line) suggests that the temperature profile may be returning to the regional (conductive) gradient. The temperature probe unfortunately failed before reaching the hole bottom $(2438 \mathrm{~m})$. However, bottom hole temperatures are indicated from maximum-reading thermometers lowered to the bottom of the hole 48 hours after mud circulation. It should be noted the 50-minute temperature recorded by the maximum-reading thermometer is not a stabilized bottom-hole temperature (Priest, 1985). The stabilized temperature should be higher than $1410 \mathrm{C}$. 


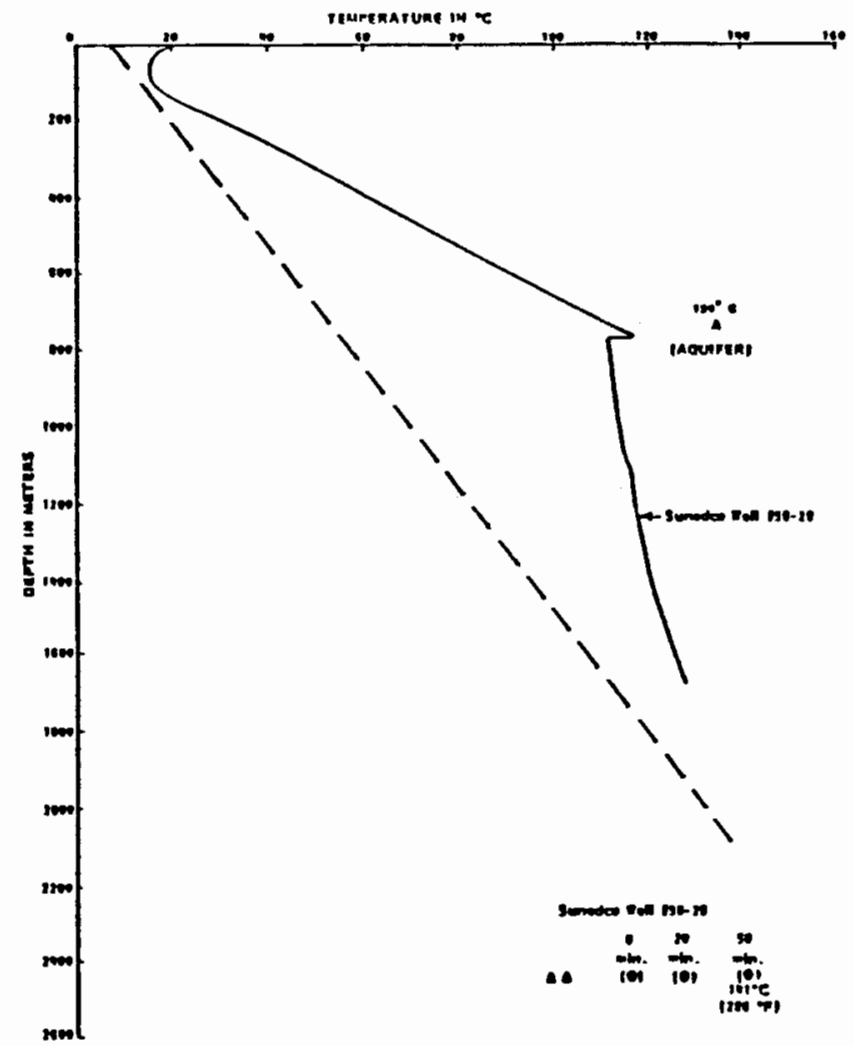

Figure 4.4. Temperature gradient in Suned co well near Ereitenbush Hot Springs. Temperature probe failed before reaching bottom of the hole. Readings of maximum reading thermometers are indicated with their residence time at the bottom of the hole. Dashed line indicates regional background temperature gradient for the High Cascade Range. (Modified from Priest, 1985.) 
The close structural, stratigraphic and lithologic similarities of McCredie Hot Springs with Breitenbush Hot Springs suggests the possibility that McCredie Hot Springs may likewise originate from convection within a shallow aquifer. The high chloride concentrations of McCredie Springs probab1y indicates deep circulation, with interaction with Eocene sediments at depth (Mariner and others, 1980). However, only moderate reservoir temperatures are indicated by the spring geochemistry. If the thermal waters have experienced deep circulation and higher temperatures, it is evident from Table 4.1 that the waters have equilibrated to lower temperature environments. Although the evidence reviewed above is not definitive in favor of any of the geothermal models, model 3 is the model best supported by the geologic, geochemical, and geophysical evidence. The high heat flow anomaly may be extended or enhanced westward by convective flow in shallow aquifers, as suggested in model 3 . This may explain the offset between the locations of the boundary of the zone of elevated isotherms calculated from aeromagnetic studies and those derived from drilling exploration. Alternatively, high conductive heat flow may characterize the western portion of the heat flow anomaly, as suggested by the gradient in the Sunedco hole in the Breitenbush area. 


\section{CHAPTER V}

\section{PETROLOGY}

The nomenclature for rocks of the Willamette Pass area used in this report has been introduced in an earlier section. Because of its intrinsic nature to the discussion of the petrology of the rocks of Willamette Pass, the nomenclature used in this report will be reviewed briefly below.

\section{$\underline{\text { Rock nomenclature }}$}

A system of nomenclature based primarily on Si02 weight percent is used in this report. The Si02 range for each rock type is:

$\begin{array}{ll}\text { Basalt } & \text { less than } 53 \% \\ \text { Basaltic andesite } & \text { between } 53 \% \text { and } 57 \% \\ \text { Andesite } & \text { between } 57 \% \text { and } 63 \% \\ \text { Dacite } & \text { between } 63 \% \text { and } 70 \% \\ \text { Rhyodacite } & \text { greater than } 70 \%\end{array}$

Analytical methods

All rocks except field samples P-604, Tmo, P-509, P626, and P-PHL were analyzed by standard atomic absorbtion methods at the University of Oregon (Christine McBirney, analyst). The remaining samples noted above were analyzed 
by standard induced argon coupled plasma techniques at the University of Utah Research Institute (Ruth Kroneman, analyst). The chemical analyses are presented in Appendix I. Locations of analyzed samples are shown on Plate A.

Method of treatment

The chemical data in the discussions and the chemical diagrams that follow have been recalculated to $100 \%$ volatile free, with all iron expressed as $\mathrm{FeO}^{*}$ (where FeO* $=\mathrm{FeO}+0.9 \mathrm{Fe} 203)$. Harker diagrams for the major elements are shown in Figures 5.1 thru 5.3. A table of symbols used for the chemical diagrams is presented in Table 5.1 . Diagrams of silica versus total alkalies and the FeO*/MgO ratio are shown in Figure 5.4. Diagrams showing trace element abundances are shown in Figures 5.5 and 5.6 .

Norms plotted in Figure 5.7 and 1 isted in Appendix I are molecular (cation) norms and are calculated using a Fe203/FeO weight ratio of 0.3 . The Fe203/FeO ratio affects normative values by varying the amount of ferric iron available for the formation of magnetite at the expense of the contending ability of ferrous iron to be incorporated into mafic silicate phases. Several published methods of determining appropriate iron oxidation ratios were considered because of concern that treating all the chemical data with the same ratio, regardless of differences in age, alteration, highest magmatic residence level, and primary water content, might be inappropriate. 


\section{TABLE 5.1}

SYMBOLS USED ON THE GEOCHEMICAL DIAGRAMS OF THIS REPORT

$\circ$

$x$

I

0

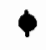

$+$
Upper High Cascade lavas and High Cascade lavas, undifferentiated

Lower High Cascade lavas

Lavas of Moss Mountain

Lavas of Tumblebug Creek

Oligocene-Miocene rhyodacites

Oligocene Miocene lavas, undifferentiated 
a)

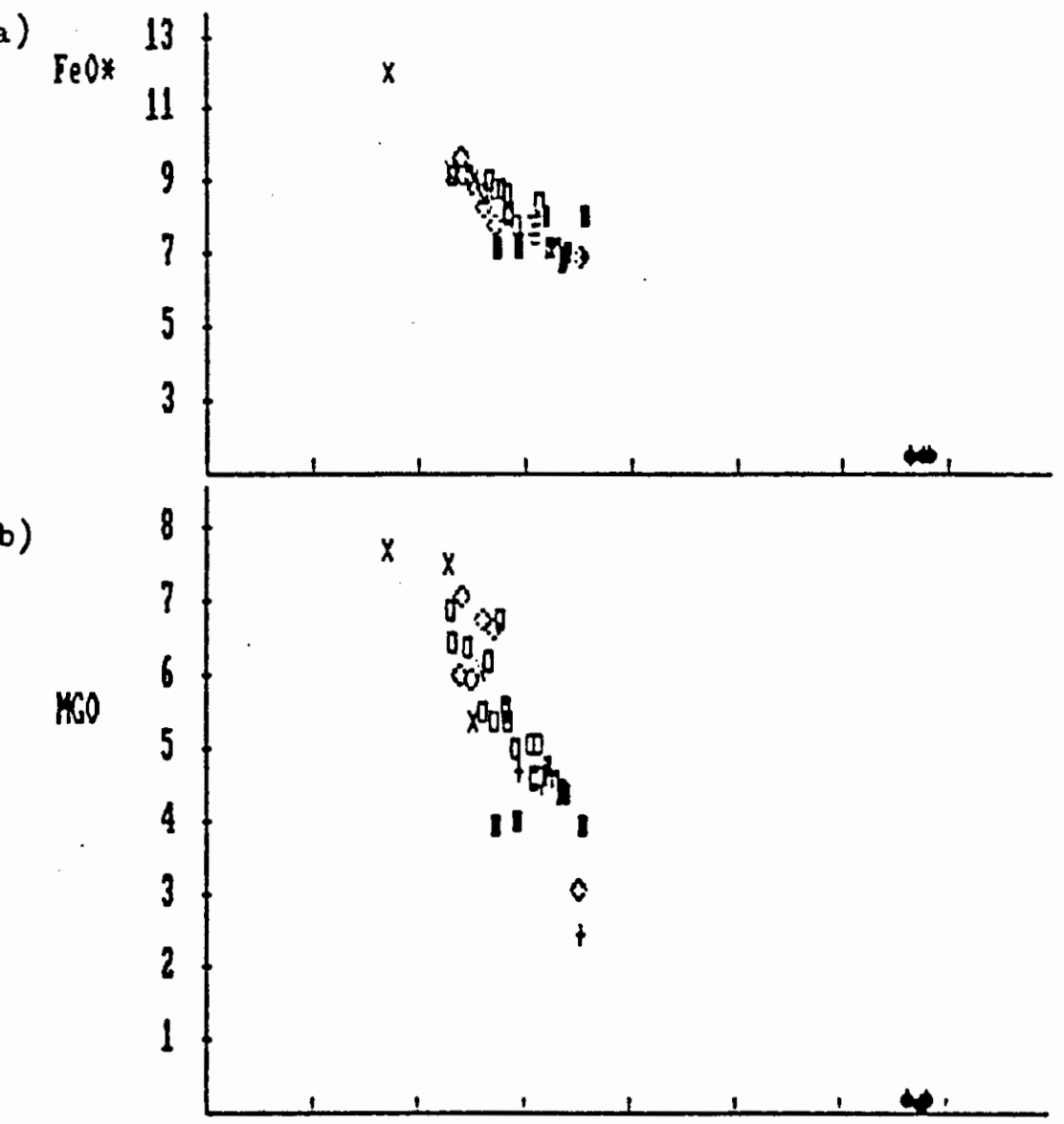

c)

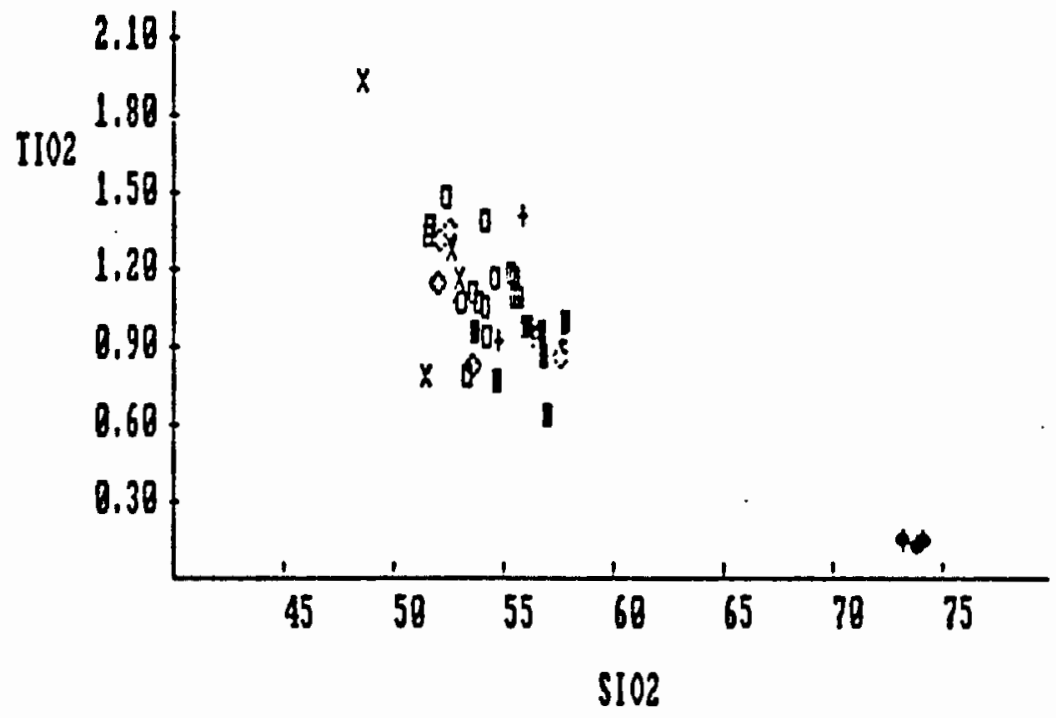

Figure 5.1. S1lica versus total iron, magnesia, and titania. Symbols as in Table 5.1. 


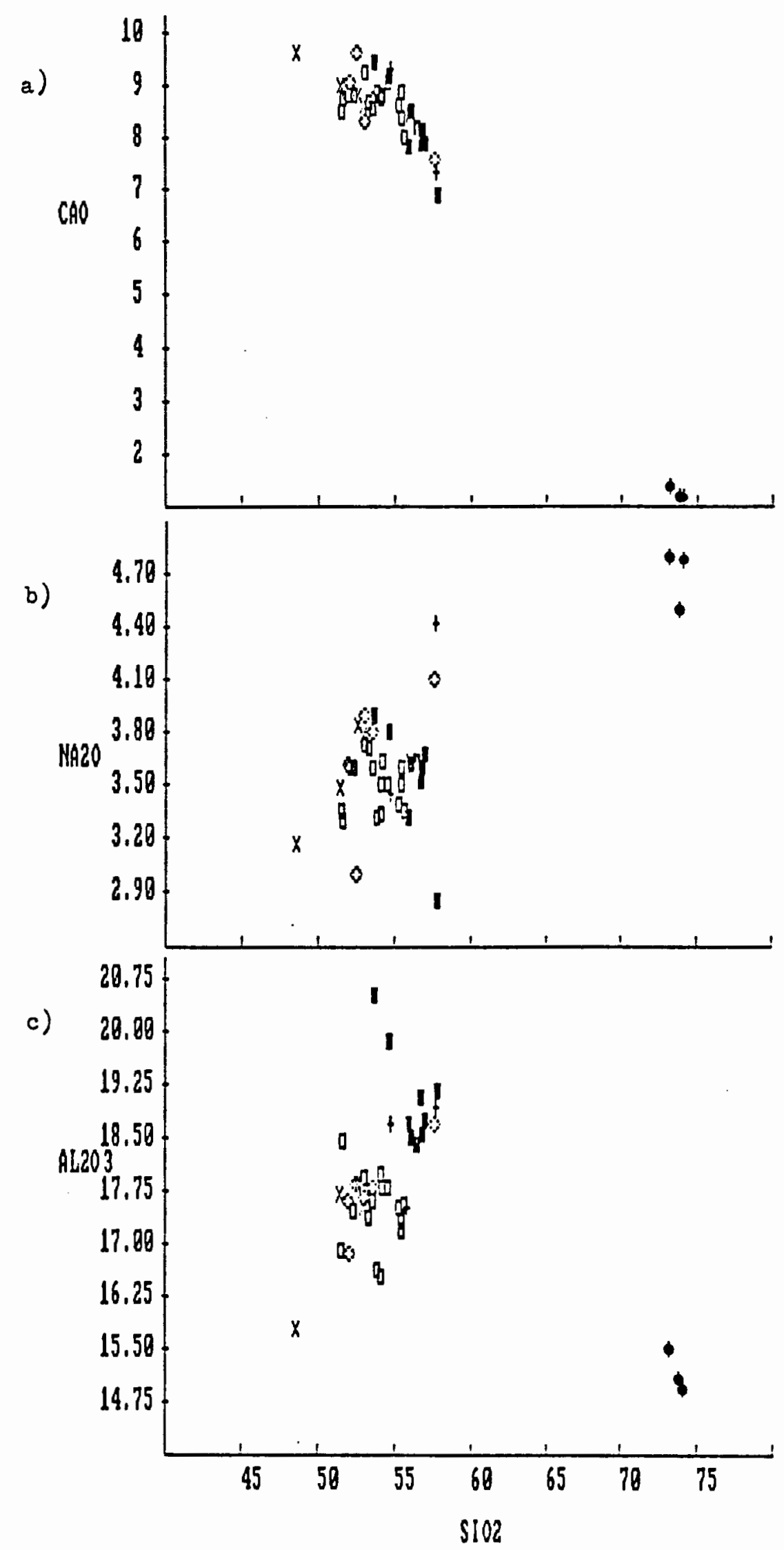


$\stackrel{\dot{0}}{\infty}$

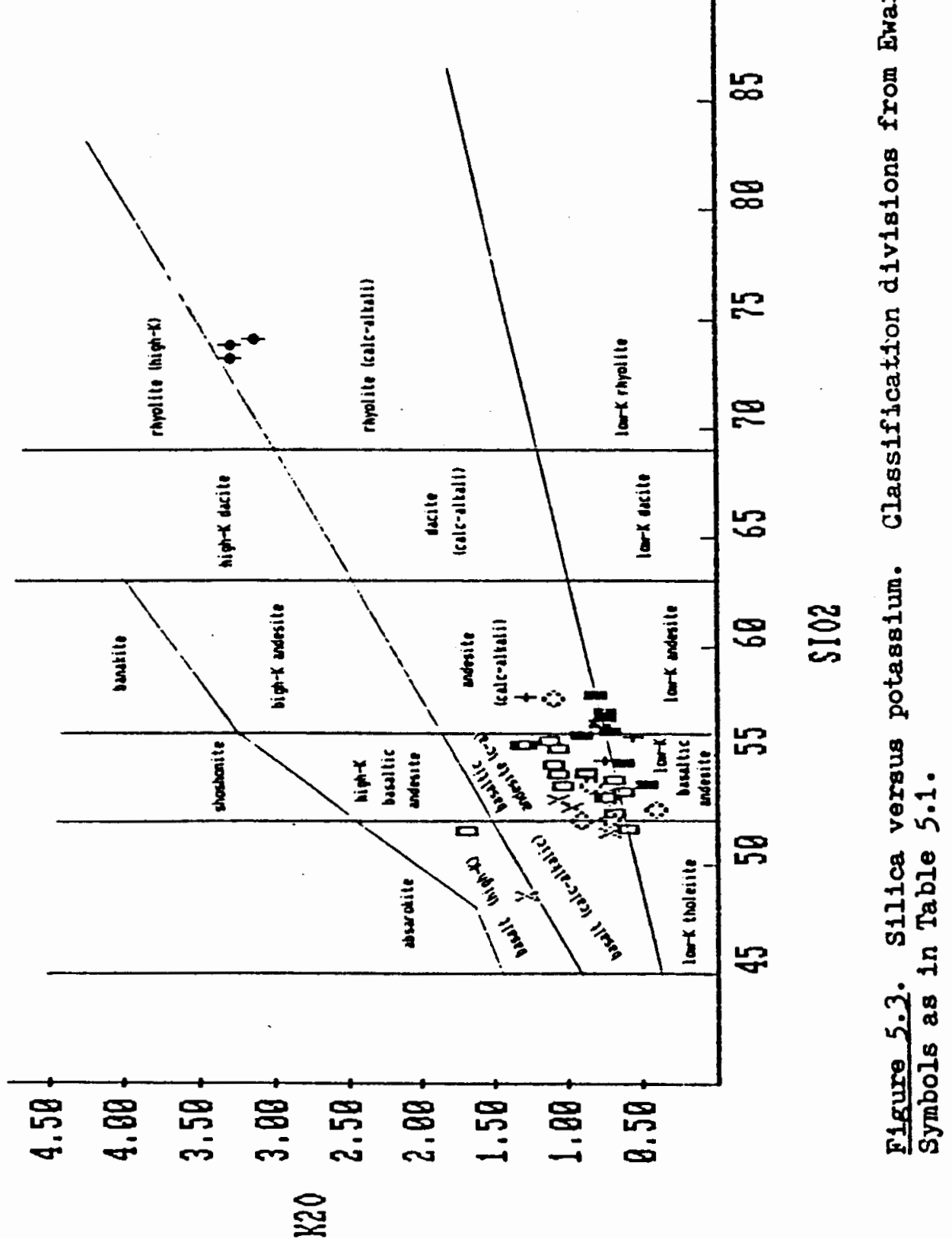



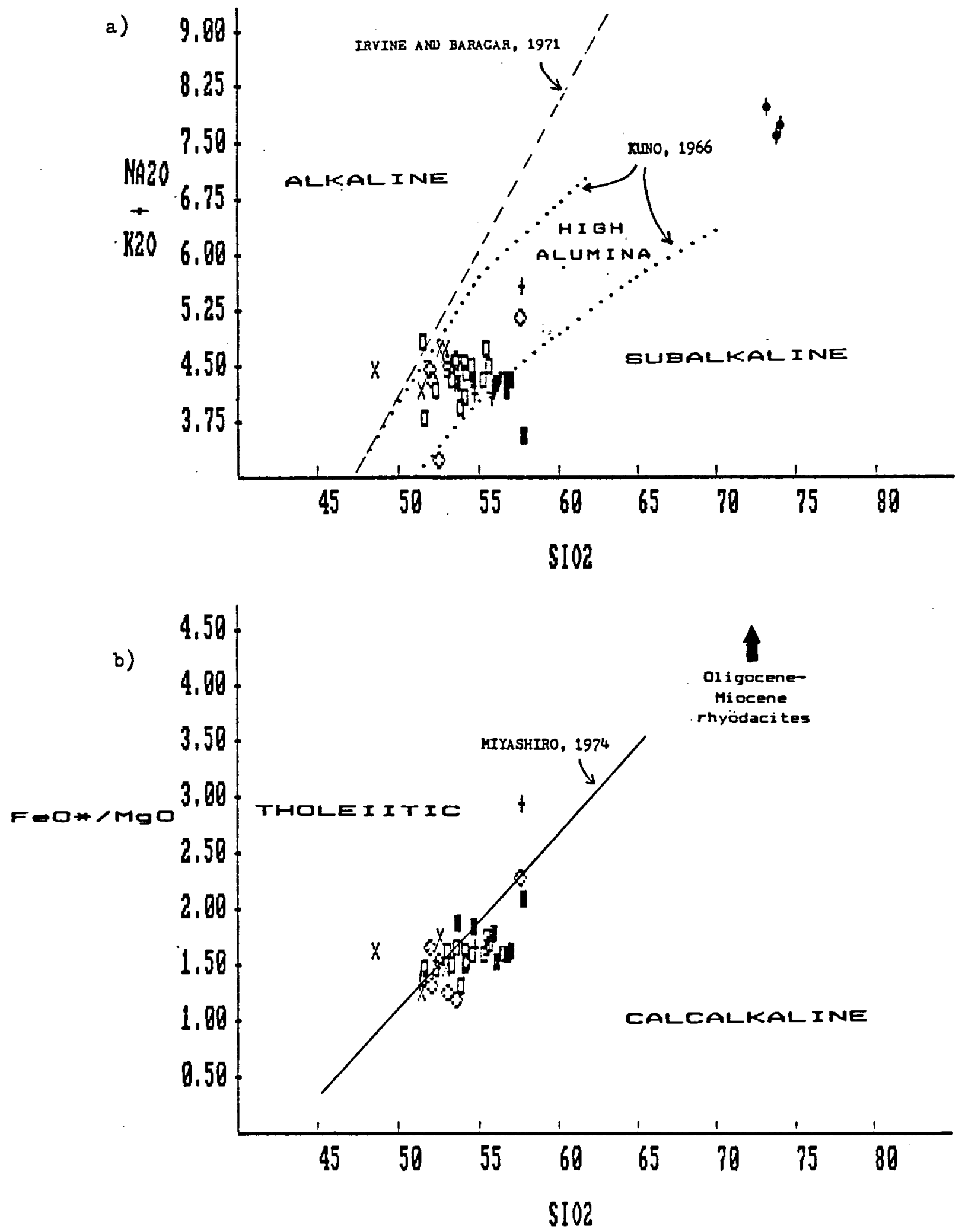

Figure 5.4. Silica versus total alkalies and FeO*/MgO. Symbols as in Table 5.1. 


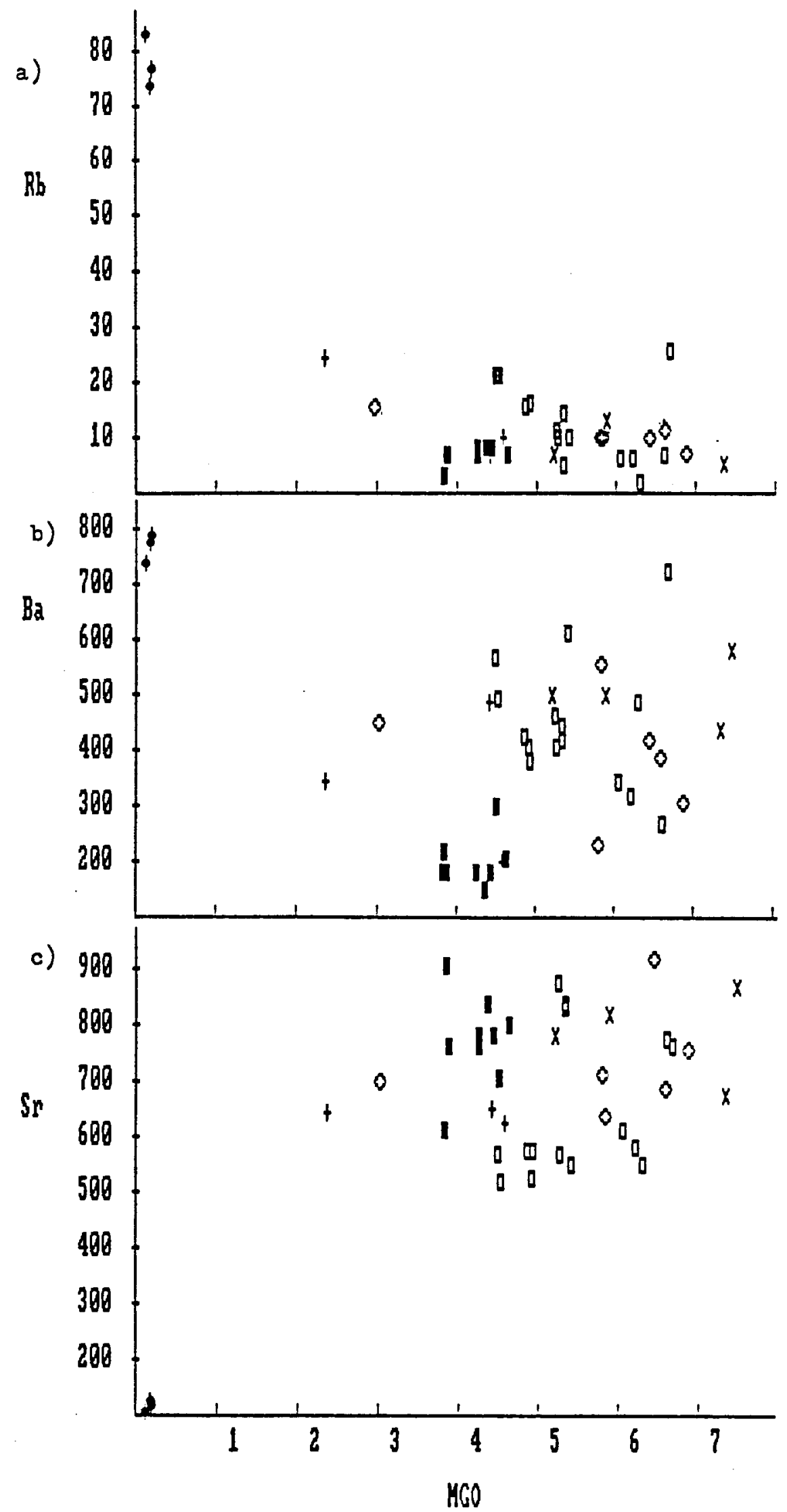


a)

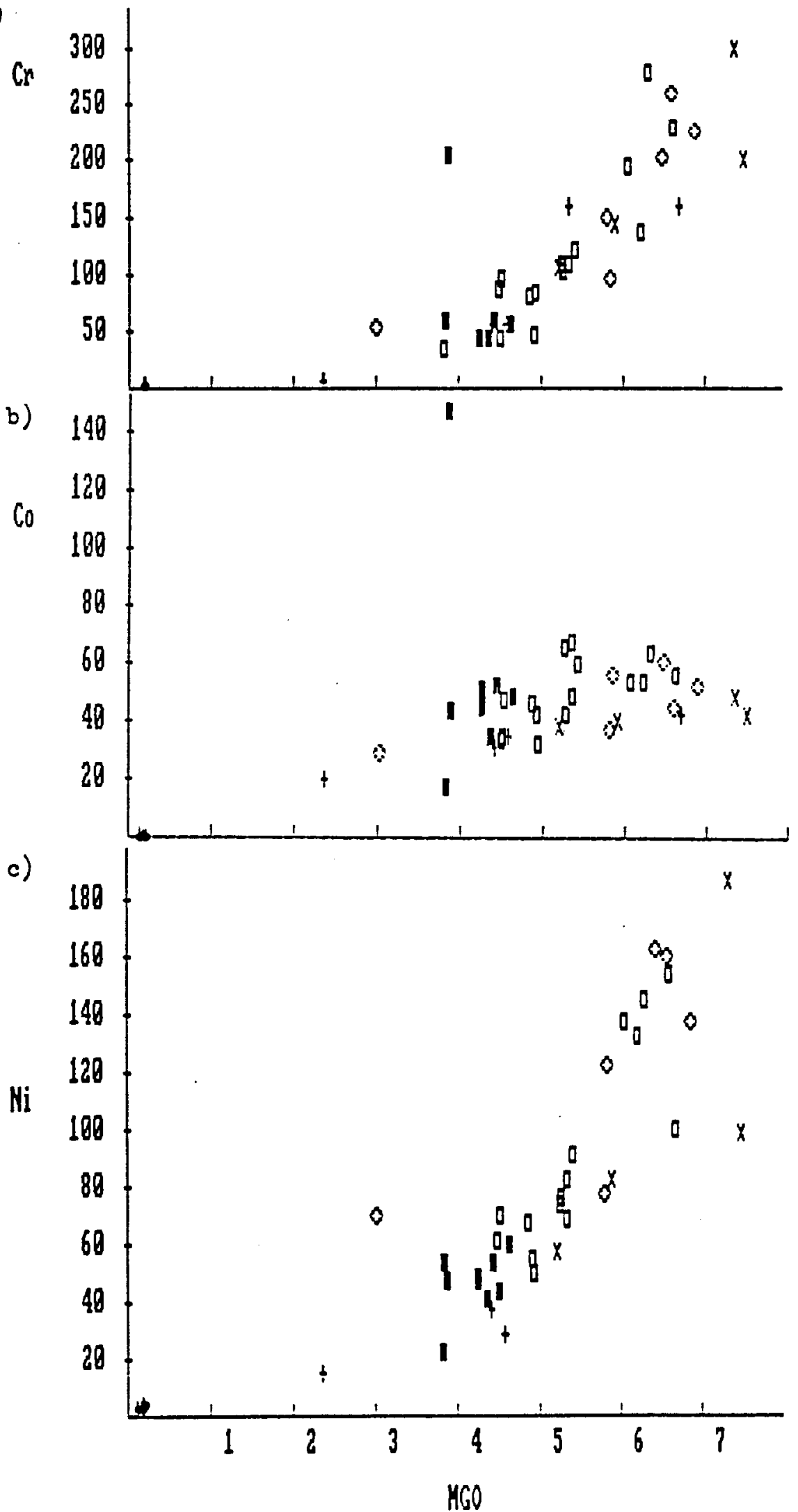



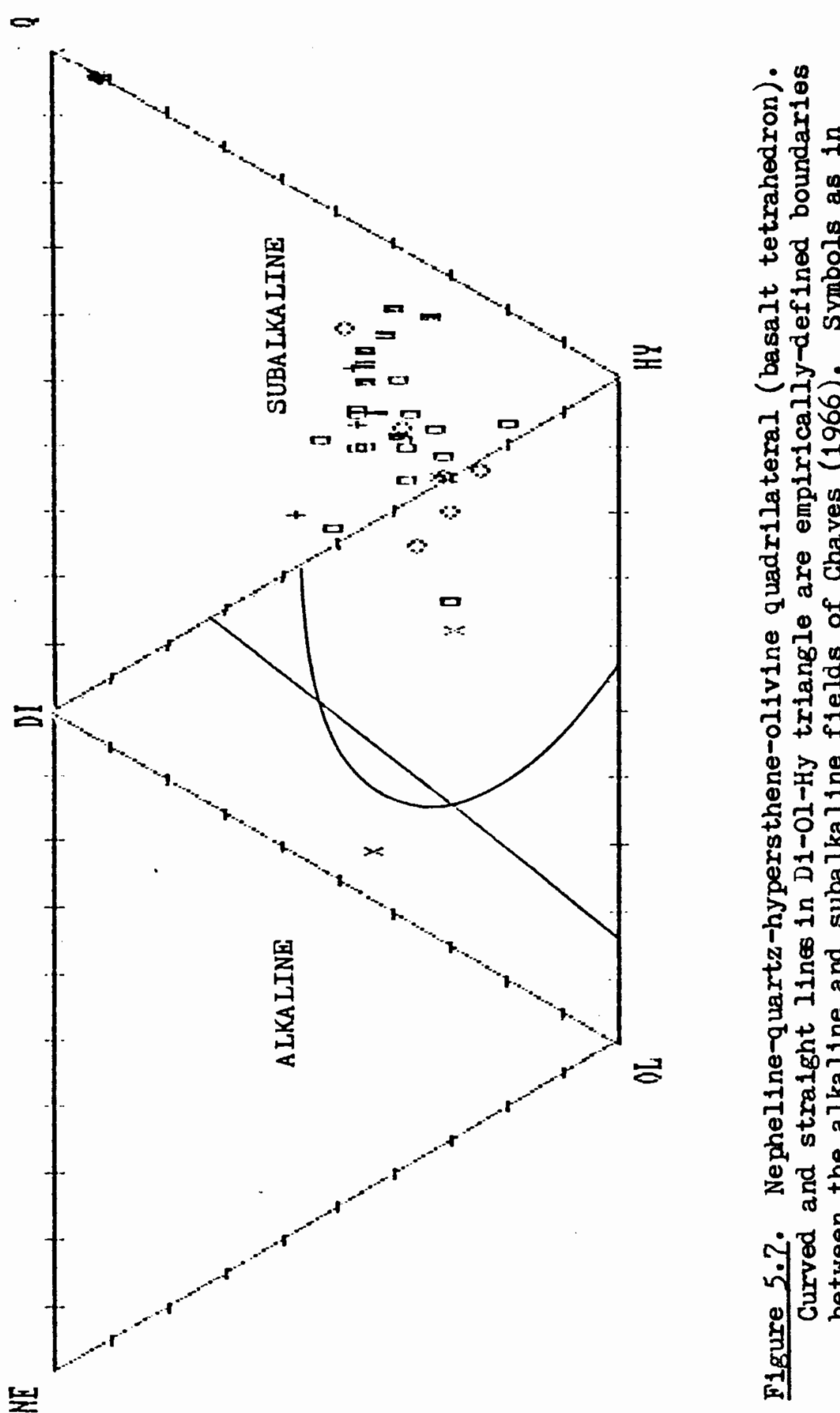
ไี่ 궁 +合色 解

?

ㄱํำ

近

吕 合

芷

㝴喪 잉 兽 ᄀᄀ 궁 궁 车 空 赶索 o 1 प्र द 출 영 马 实焉 号 空 否的 造密焉

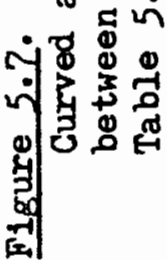


LeMaitre (1976) suggested an empirical determination using the parameters of SiO2 and total alkalies. However his method leads to an almost uniform Fe203/FeO ratio of 0.60 for this data set, a value probably too high. Brooks (1976) suggested the iron oxidation ratio (Fe203/FeO) of 0.15 be used as a standard in calculating the norms of basalts. However, Brooks does not address the problem of iron ratio in more silicic rocks. Irvine and Baragar (1971) recommended that the value of Fe203 not be a11owed to exceed the weight percentage of $\mathrm{TiO} 2+1.5 \%$. This method does not allow for significant variation in TiO2 in different rocks. In view of the l) the theoretical character of norms in the first place, 2) somewhat arbitrary choice of iron oxidation ratio, and 3) the previous studies employing iron oxidation ratios of approximate1y 0.3 (e.g., Priest and Vogt, 1983; Flaherty, 1981), 0.3 will be used in this study. The choice of 0.3 for the iron oxidation ratio is based on the oxidation ratio of the least oxidized rock sample analyzed in Priest and Vogt (1983).

The petrography of the rocks of Willamette Pass is summarized in Table 5.2.

\section{Oligocene-Miocene rhyodacites}

The approach that will be followed here will be to describe the 01 igocene-Miocene rhyodacites here, but to consider these lavas as the silicic end members of the 
TABLE 5.2

PETROGRAPHY OF THE ROCKS OF THE WILLAMETTE PASS AREA

\begin{tabular}{|c|c|c|c|}
\hline Map unit & $\begin{array}{l}\text { common rock } \\
\text { types }\end{array}$ & $\begin{array}{l}\text { common } \\
\text { pheno- } \\
\text { crysts* }\end{array}$ & $\begin{array}{l}\text { common } \\
\text { groundmass } \\
\text { textures } \\
======\Rightarrow= \pm===\end{array}$ \\
\hline \multicolumn{4}{|c|}{ 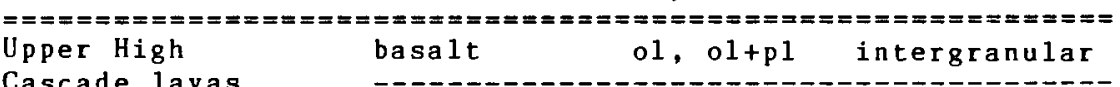 } \\
\hline Cascade lavas & \multicolumn{2}{|c|}{$\begin{array}{ll}\text { basaltic } & \text { ol, ol } 1+p 1 \\
\text { andesite } & \end{array}$} & intergranular \\
\hline \multirow{2}{*}{$\begin{array}{l}\text { Lower High } \\
\text { Cascade lavas }\end{array}$} & basa $1 t$ & $o 1,01+p 1$ & intergranular \\
\hline & $\begin{array}{l}\text { basaltic } \\
\text { andesite }\end{array}$ & $\circ 1, \quad 01+p 1$ & intergranular \\
\hline \multirow[t]{3}{*}{$\begin{array}{l}\text { Lavas of } \\
\text { Moss Mountain }\end{array}$} & andesite & $\begin{array}{l}p 1+o p x+c p x \\
p 1+o p x \\
p 1+c p x\end{array}$ & $\begin{array}{l}\text { intergranular, } \\
\text { intersertal, } \\
\text { hyaloophitic }\end{array}$ \\
\hline & dacite & $\begin{array}{l}\mathrm{p} 1+\mathrm{opx}, \mathrm{p} 1 \\
\mathrm{p} 1+\mathrm{opx}+\mathrm{h} b\end{array}$ & $\begin{array}{l}\text { intersertal } \\
\text { hyaloophitic }\end{array}$ \\
\hline & $\begin{array}{l}\text { basaltic } \\
\text { andesite }\end{array}$ & $\begin{array}{l}p 1+c p x+o 1 \\
p 1+c p x\end{array}$ & intergranular \\
\hline $\begin{array}{l}\text { Lavas of } \\
\text { Tumblebug }\end{array}$ & $\begin{array}{l}\text { basaltic } \\
\text { andesite }\end{array}$ & $\begin{array}{l}o 1, o 1+c p x \\
o 1+c p x+p 1\end{array}$ & $\begin{array}{l}\text { intergranular, } \\
\text { vesicular, }\end{array}$ \\
\hline Creek & \multicolumn{2}{|l|}{ basalt } & $\begin{array}{l}\text { intergranular, } \\
\text { vesicular, } \\
\text { marginally } \\
\text { diktytaxitic }\end{array}$ \\
\hline $\begin{array}{l}\text { Oligocene-Miocene } \\
\text { rhyodacites }\end{array}$ & $\begin{array}{l}\text { rhyodacite, } \\
\text { also includes } \\
\text { lavas similar } \\
\text { to Oligocene- } \\
\text { Miocene lavas, } \\
\text { undifferentiat }\end{array}$ & aphyric & $\begin{array}{l}\text { aphyric, } \\
\text { banded, } \\
\text { vitreous }\end{array}$ \\
\hline \multirow[t]{4}{*}{$\begin{array}{l}\text { Oligocene-Miocene } \\
\text { lavas, undiff- } \\
\text { erentiated }\end{array}$} & rhyodacite & $\begin{array}{l}\text { aphyric, } \\
\text { p } 1, p 1+h b \\
\text { p } 1+q+h b \\
\text { p } 1+q\end{array}$ & $\begin{array}{l}\text { vitrophyric, } \\
\text { banded, hyalo- } \\
\text { ophitic, }\end{array}$ \\
\hline & dacite & $\begin{array}{l}\text { aphyric, } \\
\text { p } 1, \quad p 1+q \\
p 1+q+h b\end{array}$ & $\begin{array}{l}\text { pilotaxitic, } \\
\text { intersertal, } \\
\text { hyaloophitic } \\
\text { amygdaloidal }\end{array}$ \\
\hline & andesite & $\begin{array}{l}p 1+o p x, p 1 \\
p 1+o p x+c p x\end{array}$ & $\begin{array}{l}\text { intersertal, } \\
\text { hyaloophitic } \\
\text { intergranular } \\
\text { amygdaloidal }\end{array}$ \\
\hline & $\begin{array}{l}\text { basaltic } \\
\text { andesite }\end{array}$ & $\begin{array}{l}p 1+c p x+c p x \\
p 1+c p x+o 1\end{array}$ & intergranular \\
\hline
\end{tabular}

* Key :

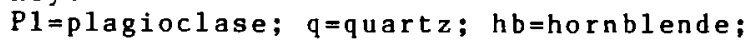
cpx=clinopyroxene (augite); opx=orthopyroxene (hypersthene); $01=011$ ine. 
equivalent 01igocene-Miocene lavas, undifferentiated, discussed in the following section.

A1l of the samples have K20 slightly over $3.0 \%$, in the calc-alkalic rhyolite field of Ewart (1982; Figure 5.4). The $\mathrm{K} 20 / \mathrm{Na} 20$ ratios range from .65 to .72 , within the characteristic ranges of both island arc and continental margin arcs (Jakes and White, 1972).

Although the three samples plot well into Miyashiro's (1974) tholeitic field in the $\mathrm{FeO} / \mathrm{MgO}$ vs SiO2 plot (Figure 5.4b), this is probably more a function of the extreme differentiation of these lavas (where the value and analytical resolution of $\mathrm{MgO}$ is low) than a fundamental character of their differentiation history. This is supported by the position of the Oligocene-Miocene rhyodacites on the $\mathrm{FeO}^{*}$ vs $\mathrm{SiO} 2$ plot (Figure 5.1a), where they lie on an extension of the calcalkaline trend of the other map units (including the 01igocene-Miocene lavas, undifferentiated).

\section{Oligocene-Miocene lavas, undifferentiated}

The 01igocene-Miocene lavas, undifferentiated, are a diverse unit. Although the unit is volumetrically dominated by intermediate to silicic pyroclastic rocks, the three analyzed samples of this unit are lavas. The three samples (two basaltic andesites and an andesite) were specifically chosen to represent the more intermediate to mafic compositions present in the unit, in order to portray 
the chemical character. Tuffs, common in the western part of the study area, were not analyzed.

Figures 5.1 - 5.3 show the scatter of the three analyzed Oligocene-Miocene lavas, undifferentiated. The two basaltic andesites plot in the empirically defined calcalkaIine field of the $\mathrm{FeO} / \mathrm{MgO}$ diagram (Miyashiro, 1974, Figure 5.4b) but the andesite falls in the tholeitic field. It is not enrichment in iron that causes the sample to plot in the tholeiite field of this diagram but rather the low MgO of this sample (Figure 5.1b). As pointed out earlier, the 0ligocene-Miocene rhyodacites, a unit considered here contemporaneous with these rocks, also plot in Miyashiro's (1974) tholeittic field, although this may also be a function of the low numerical value of $\mathrm{MgO}$ for these rocks.

The three samples fall within or on the lower boundary of the high alumina field of Kuno (1966; Figure 5.4a). The basaltic andesites also fall on the boundary of the calcalkali basaltic andesite - low-K basaltic andesite fields of Ewart (1982; Figure 5.3) and the similar classification system of the Basaltic Volcanism Study Project (1981; not shown). The $\mathrm{K} 20 / \mathrm{Na} 20$ ratio of the samples are low (about 0.2 ), which is typical of island arcs environments (Jakes and White, 1972). However, the relative scarcity of mafic lavas, the ubiquitous presence of silicic pyroclastic flows, the calcalkaline character, and trace element abundances (see below) are typical of the calc-alkaline 
trend in arcs of active continental margins (Jakes and White, 1972).

Rubidium shows an increase with increasing degree of differentiation (i.e., decreasing $\mathrm{MgO}$ ), as might be expected (Figure 5.5a). Barium, however, shows an unclear pattern characterized by large scatter, and strontium is of constant concentration between $4.5 \%$ and $2.3 \%$ magnesium (Figures 5.5b and 5.5c). The trace elements nickel, cobalt, and chromium all show constant decrease with decreasing magnesium (Figure 5.6), as would be expected from a calcalkaline differentiation trend.

The major oxide composition of the two basaltic andesites tend to plot with the lavas of Moss Mountain. The andesite sample plots in a somewhat isolated location on many of the plots by virtue of its higher Si02 and alkalies and lower $\mathrm{MgO}$ (Figures 5.1 and 5.2). The trace element contents of the two units also show considerable similarity, with overlap of the two fields on all diagrams. The strontium, nickel, and cobalt content of these lavas tend to fall in the lower portion of the chemical field of the Moss Mountain flows (Figures 5.5c, 5.6b, and 5.6c).

\section{Lavas of Tumblebug Creek}

The lavas of Tumblebug Creek were sampled extensively in the Tumblebug and Swift Creek areas. The vent in the Tumblebug Creek area, at the southern margin of the study area, was the source of most of these sampled flows, but 
some samples were also taken that originated at Jupiter Ridge.

The lavas of Tumblebug Creek are predominantly olivine-bearing basaltic andesites. They are generally quartz normative, and normative hypersthene is greater than normative diopside. The silica content for the analyzed samples is $51.9-55.8 \%$. The most mafic sample, T-1, plots in the undersaturated field (normative olivine + hypersthene field) of the Yoder and Tilley (1962) basalt tetrahedron (See Figure 5.7, an unfolded version of the Yoder and Tilley basalt tetrahedron). T-1 is a slightly altered (saponite + chlorite) basalt with celadonite-lined vesicles that crops out near the base of the exposed section at Tumblebug Creek. This sample is unusual in some of its chemical characteristics (e.g., total alkalies), and the alteration of this sample may account for some of these attributes.

The K20 of the samples of this unit occupy the lower and central portions of the calc-alkalic basaltic andesite field of Ewart, (1982; Figure 5.3). Inspection of the trend in this diagram shows enrichment of $\mathrm{K} 20$ in the more silicic lavas of this unit. Na20, on the other hand, does not exhibit an identifiable trend (Figure 5.2b). K20/Na2O ranges from .5 to .17 , a range more typical of island arcs than of arcs of active continental margins (Jakes and White, 1972). Figure 5.4a shows these lavas plot in the high alumina field of Kuno (1966). 
The lavas of Tumblebug Creek follow the calcalkaline differentiation trend with respect to iron and magnesium. $\mathrm{FeO}^{*}$ falls steadily with increasing silica (Figure 5.1a), and $\mathrm{FeO}^{*} / \mathrm{MgO}$ is about 1.5 for al1 the analyzed samples (Figure 5.4b).

Nickel and chromium decrease substantially with decreasing magnesium, but no trend is noted in the considerable scatter of the $\mathrm{MgO}$ vs. cobalt diagram (Figure 5.6). Among the LIL (large ion 1ithophile elements, i.e., rubidium, barium, and strontium) rubidium increases slightly with decreasing magnesium while the barium and strontium data are characterized by high scatter with no apparent trend (Figure $5.5 \mathrm{a}, \mathrm{b}, \mathrm{c}$ ).

\section{Lavas of Moss Mountain}

The lavas of Moss Mountain are phyric pyroxene-bearing andesites, basaltic andesites and dacites. The range of silica in the analyzed flows is $53.8-57.8 \%$, and are therefore predominantly basaltic andesites. Many of the flows are two pyroxene phyric, with augite and hypersthene occurring as the phenocryst phases. The basaltic andesites commonly bear olivine as well as augite and tend to occur toward the top of the sequence. The dacites are most common toward the bottom of the unit, and are glassy or fine grained.

The chemistry of these rocks is considered transitional between the $10 w-K$ and calc-alkali fields of 
andesite and basaltic andesite in the classification of Ewart (1982; Figure 5.3). K20 increases with increasing silica while Na20 decreases (Figure 5.2b). The total alkali content of the lavas of this unit plot in the high alumina and tholeiite series fields of Kuno (1966) and in the subalkaline field of Irvine and Baragar (1971; Figure 5.4a). The corresponding decrease in $\mathrm{A} 1203, \mathrm{CaO}$, and $\mathrm{Na} 20$ with increasing silica on Figure 5.2 suggests fractionation or addition of plagioclase. The lavas of Moss Mountain have higher alumina in comparison to the lavas of Tumblebug Creek at the same silica content. Plagioclase is the only common mineral with more alumina than intermediate calcalkaline rocks. If plagioclase were being removed from the melt, the alumina would be depleted. Therefore, the chemical trends of Figures 5.1 and 5.2 suggest plagioclase addition. Plagioclase fractionation should not be surprising in view of the common plagioclase-phyric nature of these rocks. Ewart (1976) noted a positive statistical correlation between alumina, calcium, and \% modal phenocryst plagioclase among reported andesite compositions (with the exception of the hornblende andesites) and concluded that plagioclase is a cumulus phase in crystalrich andesites.

Rubidium and barium are both low (Figure 5.5a,b) and follow the similar low concentration of potassium already discussed. Both of these elements have lower concentrations than in equally differentiated flows of 
lavas of Tumblebug Creek. Strontium, however, is higher in concentration than in analyzed samples of lavas of Tumblebug Creek at equivalent magnesium contents (Figure 5.5c). This too suggests plagioclase enrichment of the magma .

The compatible trace elements exhibit virtually

identical or continuous trends with the lavas of Tumblebug Creek (Figure 5.6).

High Cascade lavas

The upper and lower High Cascade lavas are olivine bearing basalts and basaltic andesites. Silica in the ten analyzed samples ranges from 48.6 to $56.7 \%$. The High Cascade lavas bear many physical and chemical similarities to the lavas of Tumblebug Creek. It is frequent1y difficult to distinguish between the two rock units in the field. The chemical character of these two units is likewise similar, with their respective fields overlapping and colinear on all plots.

The most profound difference between the Miocene lavas of Tumblebug Creek and High Cascade lavas is the tendency of the latter to be more mafic than the older unit, although there is considerable overlap in the two fields. This is evident from inspection of the unfolded basalt tetrahedron of Yoder and Tilley (1962; Figure 5.7). In this diagram five High Cascade lavas are silica undersaturated (olivine tholeites) while three others are 
silica saturated. Normative hypersthene is greater than normative diopside, and therefore do not qualify as high alumina basalts according to the definition of Yoder and Tilley (1962). However, the unit would be categorized as high alumina basalt by the standards of Kuno (1966; Figure $5.4 \mathrm{a})$.

The K20 and rubidium concentrations of the High Cascade lavas do not vary significantly with decreasing MgO (Figure 5.5a). This is in contrast to the increase of K20 and rubidium with decreasing MgO of the lavas of Tumblebug Creek. This may be a function of the sampling of the latter unit - most of the analyzed samples of the lavas of Tumblebug Creek are from a single volcano.

Barium and strontium show large scatter with no identifiable trend with respect to MgO (Figure 5.5b,c). Lower High Cascade lavas have higher barium than upper High Cascade lavas, the on $1 y$ differing chemical characteristic of the two units (Figure 5.5b). Sample T-205a, here plotted with the upper High Cascade lavas although mapped as High Cascade lavas, undifferentiated, may in fact be a flow of the lower High Cascade 1avas.

The High Cascade lavas and lavas of Tumblebug Creek have similar compatible trace element characteristics (Figure 5.6).

One sample of the High Cascade lavas (field sample PPHL, an olivine basalt) plots in the empirically defined alkaline field of Chayes (1966) on the unfolded basalt 
tetrahedron diagram (Figure 5.7) as well as the alkaline field of Irvine and Baragar (1971; Figure 5.4a). P-PHL has 48.61\% silica and $7.49 \%$ magnesium. It is the most mafic of the analyzed High Cascade lavas. The high alkali content of this sample is principally due to potassium. Potassium is distinct 1 y higher than in the other High Cascade lavas (even though it is by far the most silica-poor sample), plotting just into the high-K basalt field in the classification of Ewart (1982; Figure 5.3). Sodium is lower in this sample than in most of the other High Cascade lavas. P-PHL also has other alkaline characteristics, such as high iron and titanium. Jan (1967) and Milhollen (unpublished manuscript) have identified nepheline normative High Cascade lavas while "mild1y a1ka1ine basalts" (Flaherty, 1981) have been identified in other Cascade studies (e.g., Flaherty, 1981; McBirney, 1968). It is clear from the literature, however, that these mild ly alkaline flows are of limited number and volume in the Cascades.

Sample P-Notch, the most siliceous of the High Cascade lavas, is an andesite, and a comparison with the andesitic lavas of Moss Mountain is appropriate. The total iron, alumina, titanium, $\mathrm{Fe} 0^{*} / \mathrm{MgO}$, and calcium are essentially at the same levels as those of the older unit. However the alkalies and phosphorus are all significantly higher, while magnesium is significantly lower. Of the trace elements rubidium and barium are higher while cobalt is 1ower. A11 
the other trace elements are of similar concentrations as in the lavas of Moss Mountain. In comparing the trace elements, note the silica contents are equivalent but magnesium is substantially lower in P-Notch. This indicates P-Notch and the lavas of Moss Mountain are chemically different.

\section{Discussion}

There has been an overall trend to progressively more mafic compositions recorded in the volcanic sequence of the Willamette Pass area. Other researchers have noted a similar trend in other areas of the Oregon Cascades (e.g., Priest and others, 1983; White and McBirney, 1978). The ashflow volcanism of the Oligocene-Miocene lavas, undifferentiated, and the calcalkaline andesite-basaltic andesite association of the middle Miocene in the Cascades are typical of island arc volcanism constructed on continental crust (Jakes and White, 1972; Miyashiro, 1974). Low-K basaltic andesites of the lavas of Moss Mountain (Figure 5.3) are more common in island arcs than in active continental margins.

Despite this overall trend to increasingly mafic volcanism from the Oligocene into the present, the chemistry of the intermediate to mafic rocks of Willamette Pass presented in Figures $5.1-5.3$ exhibit remarkably consistent trends. With the exception of the SiO2 vs. A1203 diagram (Figure 5.2c), the individual fields of the 
different lithologic units overlap or lie in very close proximity to the fields of the other units.

The evolution of volcanic arcs into volcanism with common silica-undersaturated basaltic chemistry, as in the Oregon Cascade Range, is not predicted by the models (e.g., Miyashiro, 1974). Miyashiro (1974) explained the maturation of island arcs by the thickening of the continental crust by volcanic activity and suggested the maturation of an arc should be accompanied by a progressive increase in silica of lavas.

Priest and others (1983) and Flaherty (1981) showed that some High Cascade lavas have chemical affinities to the Quaternary lavas of the northern Basin and Range. These lavas have mild iron enrichment characteristics of the tholeiitic differentiation trend while others exhibit slight alkali enrichment (Priest and others, 1983). Priest and others (1983) suggested that the extensional processes affecting the Basin and Range may also be influencing magma generation beneath the Cascades. The tholeiitic flows of the High Cascade lavas are not represented in the chemical samples of the High Cascade lavas analyzed here, but field sample P-PHL would be considered mildly alkaline.

P-PHL was dated at $5.56+/-0.34 \mathrm{Ma}$. It is

interesting that the 5.5 Ma date seems to occur with surprising frequency in lower High Cascade equivalent-lavas along the Eugene-Denio trend. Sample P-324 was dated at $5.53+/-0.41 \mathrm{Ma} . \mathrm{P}-324$ is very slightly quartz 
normative, and would be classified a tholeiite (or hypersthene basalt) by Yoder and Tilley (1962). P-PHL directly overlies lavas of Moss Mountain while P-324 overlies a moderately thick series of lower High Cascade lavas. It is unlikely that P-PHL can be parental to P-324 and the other calcalkaline lower High Cascade lavas analyzed for this study because any process that enriches the P-PHL magma in silica would also enrich it in alkalies and incompatible elements.

Woller and Priest (1983) dated the capping flow at Patterson Mountain at $5.5 \mathrm{Ma}$, and Millhollen (unpublished manuscript) dated two more flows in the Saddleblanket Mountain area (just north of the Lookout Point area described by Woller and Priest) at approximately the same age. In both of these studies, the authors concluded the onset of volcanism equivalent to the lower High Cascade lavas commenced about $5.5 \mathrm{Ma}$. The flows dated by Millhollen are nepheline normative basalts, and, of the four samples of lower High Cascade equivalents he analyzed, two would be considered by Ewart's (1982) classification (see Figure 5.3) marginal absarokites, another would be a high-K basalt, and the last a calc-alkali basalt. The Patterson Mountain flow plots very close to the alkali basalt-high alumina boundary on the SiO2 vs. alkalies diagram but plots well within the olivine tholeiite field of the basalt tetrahedron diagram. It is possible that High Cascade alkaline lavas and lavas with moderate 
alkaline affinities were erupted as a pulse around $5.5 \mathrm{Ma}$. A much more thorough sampling study with additional chemical and K-Ar data coupled with more complete detailed mapping of the Cascades will be needed to test this possibility

Lavas with alkaline affinities occur in extensional environments and are common in the Basin and Range province (Leeman and Rogers, 1970; Hart and Mertzman, 1983). Diktytaxitic texture is common among the young mafic lavas of the Basin and Range (Hart and others, 1984; Hart and Mertzman, 1983; McKee and others, 1983), and also occurs among the High Cascade lavas (Priest and others, 1983; Flaherty, 1981; Rol1ins, 1976). However, it is not as common in the Willamette Pass area as it is in areas of the Cascades to the north (e.g., Priest and Woller, 1983; Rollins, 1976). The chemical and textural similarities of the High Cascade lavas and the Basin and Range lavas suggest some of the same petrogenetic forces may be operative.

Christiansen and Mckee (1978) suggested that the locus of active volcanism and extension of the Basin and Range became increasingly concentrated into the margins of the province. Luedke and Smith (1982), Walker and Nolf (1981), and MacLeod and others (1975) describe a progressive decrease in age of silicic volcanism from east to west across the High Lava Plains. The youngest silicic center in this trend, Newberry volcano, is (arguably) considered a 
part of the Cascade chain and lends support to the implication that, in this area at least, northern Basin and Range processes are affecting the Cascade Range. Basin and Range faults in the Klamath graben strike directly into/under the Cascade Range at Crater Lake, and may be one of the factors that created the volcanic center at Mt. Mazama.

Priest and others (1983) suggested that north-south normal faulting (E. M. Taylor, 1968, 1981; Brown and others, 1980a; F1aherty, 1981; Avramenko, 1981; Priest and Wo11er, 1983; Barnes, 1978; Maynard, 19/4; Hardiman, unpublished mapping; Woller and Black, 1983; see Figure 1.2) in the Cascade Range, similar to the predominant Basin and Range trend, began in the Cascades about 4 Ma and possibly as long ago as $10 \mathrm{Ma}$. They suggested that the beginning of High Cascade-type volcanism (about $8 \mathrm{Ma}$ ) may have been the petrologic response to the beginning of eastwest relaxation and extension related to Basin and Range processes affecting the Cascade Range.

We11s and others (1984) suggested that the mafic volcanism of the High Cascades may have been caused by the east-west extension resulting from the migration of the spreading ridge away from the continental margin after its closest approach about $12 \mathrm{Ma}$. 
Comparison of the chemistry of the lavas of Willamette Pass with other arc lavas.

The comparisons that follow will compare selected Willamette Pass lavas with silica-equivalent chemical analyses from the literature. As discussed above, Willamette Pass lavas form very coherent clusters or trends on all the diagrams presented in this study. Therefore a representation of Willamette Pass lavas at several silica contents will adequately represent all the lavas of the study area. This is conveniently done by selecting the chemical data of the silica-median samples of the High Cascade lavas, lavas of Tumblebug Creek, and lavas Moss Mountain, respectively. These are the first three samples listed in Table 5.3. Table 5.3 also lists the typical rock chemistry of other arc environments on the Pacific rim. Refer to this table for the following discussion.

Samples 1 and 2 are lavas from Central America, a tectonic environment that has many similarities to the Cascade Range. The similarities include: 1) oblique approach of the subducting plate to the volcanic arc, 2) the subducting lithosphere is relatively youthful in age, and therefore warm and buoyant, 3) the rate of convergence of the two plates is comparable (Drummond and others, 1981). The Willamette Pass lavas are less aluminous and more magnesian than the Central American samples. Accordingly, normative quartz and orthoclase are 
TABLE 5.3

COMPARISON OF THE CHEMISTRY OF WILLAMETTE PASS ROCKS

WITH ROCKS OF OTHER VOLCANIC ARCS

The first three samples represent the High Cascade lavas, the lavas of Tumblebug Creek, and the lavas of Moss Mountain respectively. The rocks from other arcs were chosen as typical of their environments at comparible silica contents as the three samples from Willamette Pass. All analyses are recalculated to $100 \%$ volatile free, with all iron as Fe0*. Molecular norms are calculated using an Fe203/FeO ratio of 0.30 .

$\begin{array}{lrrrrrr}\begin{array}{l}\text { Ident. } \\ \text { \# }\end{array} & \text { T-211 } & \text { T-4 } & \text { P-32 } & 1 & 2 & 3 \\ --1 & & & & & \\ \text { Si02 } & 52.85 & 54.00 & 56.16 & 54.43 & 53.83 & 58.32 \\ \text { Ti02 } & 1.33 & 1.04 & .96 & .66 & .93 & .59 \\ \text { A1203 } & 17.86 & 16.61 & 18.43 & 18.11 & 18.21 & 17.71 \\ \text { Fe0* } & 8.74 & 8.51 & 6.94 & 6.62 & 9.21 & 7.43 \\ \text { MnO } & .15 & .16 & .12 & .13 & .15 & - \\ \text { MgO } & 5.85 & 6.63 & 4.63 & 5.24 & 4.66 & 3.58 \\ \text { CaO } & 9.47 & 8.73 & 8.34 & 9.82 & 8.90 & 8.80 \\ \text { Na20 } & 2.99 & 3.30 & 3.57 & 3.62 & 2.94 & 2.67 \\ \text { K20 } & .41 & .68 & .70 & .57 & .78 & .71 \\ \text { P205 } & .35 & .33 & .14 & .06 & .16 & - \\ & & & & & & \\ \text { Q } & 3.77 & 2.86 & 6.23 & 12.02 & 5.04 & 13.19 \\ \text { Or } & 2.43 & 3.99 & 4.15 & 9.54 & 4.67 & 4.26 \\ \text { Ab } & 26.91 & 29.48 & 31.99 & 29.58 & 26.63 & 24.32 \\ \text { An } & 34.15 & 28.43 & 32.08 & 30.69 & 34.42 & 34.61 \\ \text { Di } & 8.52 & 10.02 & 6.59 & .57 & 7.20 & 7.67 \\ \text { Hy } & 19.52 & 20.99 & 15.62 & 13.18 & 18.11 & 13.27 \\ \text { O1 } & 0 & 0 & 0 & 0 & 0 & 0 \\ \text { Mt } & 2.16 & 2.10 & 1.71 & 2.25 & 2.29 & 1.86 \\ \text { I1 } & 1.86 & 1.45 & 1.33 & 1.65 & 1.30 & .83 \\ \text { Ap } & .73 & .70 & .29 & .53 & .34 & -\end{array}$

1 East of Matagalpa, Honduras (Sample N-195, Williams and McBirney, 1969).

2 Apoyo Caldera, Nicaragua (Sample 12, Ui, 1972). 3 "Low-K andesite", average of Saipan andesites (Taylor, 1969). 
Table 5.3 continued.

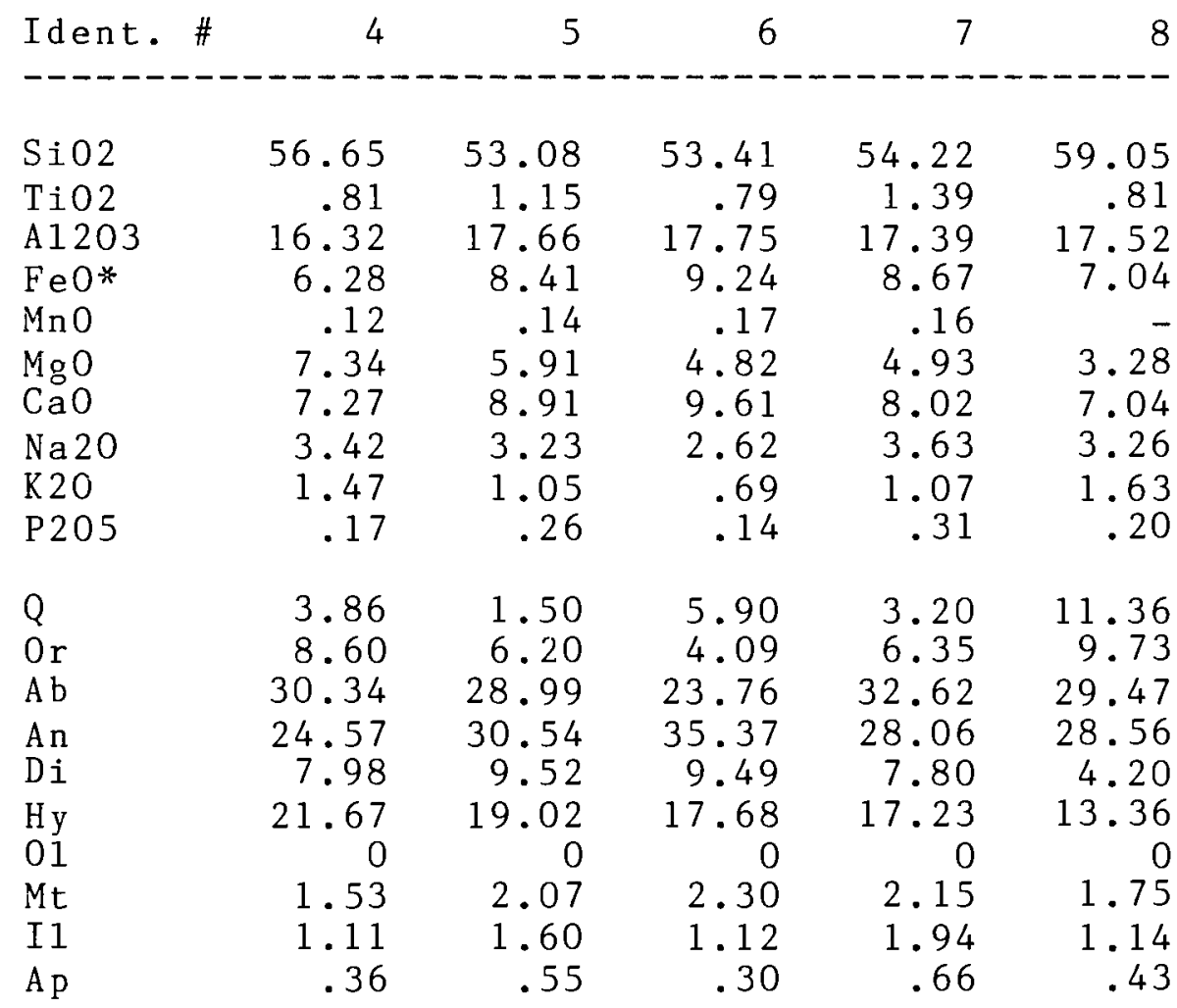

4 Mt. Lassen, California (sample 16, Smith and Carmichael, 1968).

5 Average western American basalt (includes western North and South America and Central America; Ewart, 1976 ).

6 Average island arc basaltic andesite (includes western and northern Pacific and Carribean; Ewart, 1976). 7 Average western American basaltic andesite (includes western North and Soutii America and Central America; Ewart, 1976).

8 Average Cenozoic andesite (Chayes, 1969). 
significantly lower, whereas diopside and hypersthene are higher.

Sample 3 is the average of Saipan andesites, considered $10 w-K$ andesite by Taylor (1969). Despite the higher silica of this analysis in comparison with $P-32$, the potassium levels are equivalent. Normative orthoclase is also equivalent. Sodium is conspicuously lower in the Saipan lavas. Normative albite is consequent 1 y much lower in the Saipan arc lavas.

Mt. Lassen lavas, from the southern Cascade Range, are represented by sample 4. P-32 is significantly less magnesian and potassic than sample 4, but its titanium, alumina, and calcium are higher. Consequently the anorthite of $\mathrm{P}-32$ is much higher than the Mt. Lassen sample while hypersthene and orthoclase are much lower.

Number 5 is the average chemical composition of the basalts from the active continental margins of North, Central, and South America (Ewart, 1976). Note that the silica content of this average would not qualify as basalt by the usage of this paper (it would be a basaltic andesite). The major difference between sample T-211 and sample 5 is in the potassium content. As suggested by Figure 5.3, the potassium of $\mathrm{T}-211$ is much lower than in most typical, silica-equivalent lavas of active continental margins. Sodium is also lower. However, calcium is slightly higher. In terms of normative values, T-211 has lower orthoclase and slightly higher anorthite and quartz. 
Similar relationships exist between sample $\mathrm{T}-4$ and number 7 , the average basaltic andesite of the active continental margins of the Pacific rim (Ewart, 1976). However, T-4 has significantly higher magnesium than the basaltic andesite average, partly at the expense of alumina.

The chemistry of the average island arc basaltic andesite is presented as number 6 in Table 5.3. The Willamette Pass lavas have lower iron but higher magnesium, titanium, and sodium. Their normative albite and hypersthene are consequently higher while anorthite is lower.

The last sample, number 8 , is the average Cenozoic andesite (Chayes, 1969). It has higher silica than P-32, but, except for higher magnesium and lower potassium, otherwise shows similar major element abundances.

\section{Petrogenesis}

Petrogenesis of the map units for which there is sufficient data will be treated in this section. For the following discussions of petrogenesis, refer to Table 5.4. Table 5.4 is modified from Conrey (1985) and shows mineral compositions that should be expected for calcalkaline rocks. The analyses come from a variety of sources, and the reader is referred to Conrey (1985) for references for the analyses. 
TABLE 5.4

CHEMISTRY OF TYPICAL PHENOCRYST MINERALS

IN CALC-ALKALINE ROCKS

(Modified from Conrey, 1985)

\begin{tabular}{|c|c|c|c|c|c|}
\hline Analysis & $85 \mathrm{PLAG}$ & $75 \mathrm{PLAG}$ & $\underline{6} 1 \mathrm{PLAG}$ & 50PLAG & $850 \mathrm{~L}$ \\
\hline $\mathrm{SiO} 2$ & 47.3 & 49.7 & 53.4 & 55.0 & 40.1 \\
\hline Ti02 & - & - & - & - & .02 \\
\hline A1203 & 33.0 & 32.6 & 29.3 & 28.4 & 0.05 \\
\hline $\mathrm{FeO}$ & 0.5 & - & 0.7 & - & 15.0 \\
\hline $\mathrm{CaO}$ & 17.2 & 15.3 & 12.3 & 10.5 & 0.3 \\
\hline $\mathrm{MgO}$ & 0.2 & - & - & - & 45.8 \\
\hline $\mathrm{Na} 20$ & 1.70 & 2.6 & 4.37 & 5.1 & - \\
\hline $\mathrm{K} 20$ & 0.02 & - & - & - & - \\
\hline $\mathrm{CaO} / \mathrm{FeO}$ & 34.4 & - & 17.6 & - & 0.0 \\
\hline $\mathrm{CaO} / \mathrm{A} 1203$ & 0.52 & 0.47 & 0.42 & 0.37 & 6.0 \\
\hline $\mathrm{CaO} / \mathrm{Na} 20$ & 10.1 & 5.9 & 2.8 & 2.1 & - \\
\hline $\mathrm{FeO} / \mathrm{MgO}$ & 2.5 & - & - & - & .3 \\
\hline
\end{tabular}

Analysis

$\underline{\mathrm{AUG}}$

HYP

$\underline{M A G}$

AMPH

SiO2

52.0

55.2

0.6

42.7

TiO2

A 1203

0.57

0.2

14.2

3.6

2.24

1.0

3.1

11.5

$\mathrm{FeO}$

9.28

14.8

$\mathrm{CaO}$

18.3

1.8

78.0

10.4

16.6

0.1

11.1

$\mathrm{MgO}$

$\mathrm{Na} 2 \mathrm{O}$

0.27

28.0

2.3

14.3

$\mathrm{K} 20$

$\mathrm{CaO} / \mathrm{FeO}$

$-$

$\mathrm{CaO} / \mathrm{A} 1203$

2.0

$-$

$-$

2.5

$\overline{0}$

0.3

8.2

0.1

$\mathrm{CaO} / \mathrm{Na} 20$

1.8

1.1

67.8

0.0

1.0

$\mathrm{FeO} / \mathrm{MgO}$

0.6

$\overline{0} .5$

4. 4

85PLAG: Plagioclase An 85

75PLAG: Plagioclase An 75

61PLAG: Plagioclase An 61

50PLAG: Plagioclase An 50

850L:

AUG :

Olivine Fo 85

HYP :

Augite

MAG:

Hypersthene

AMPH :

Magnetite

Amphibole 
In the following discussions, trace element distribution coefficients are used to discuss petrogenetic hypotheses. Reviews of distribution coefficient studies for andesites by Gill (1978) and for basaltic lavas by Irving (1978) were the sources for distribution coefficients used in these discussions, unless otherwise noted.

Magma generation begins with the partial melting of mantle peridotite, and the degree of partial fusion (Yoder and Tilley, 1962) and the pressures at which the ascending 1iquid is allowed to equilibrate (0'Hara, 1965) determine the eventual nature of the magma.

Yoder (1969) discussed the melting of peridotite at 20 kb. Under anhydrous conditions the first liquids are olivine tholeite in composition, with olivine and subcalcic augite as liquidus phases. The same peridotite would melt under hydrous conditions producing a first melt whose 1 iquidus phases are two pyroxenes plus quartz, an andesitic me1t. Primary andesitic melts may therefore be produced from peridotite mantle. Yoder suggested that calc-alkaline andesites are the hydrous analogues of tholeitic flood basalts.

Magmas are saturated with pyroxene and olivine at the time of their separation as a partial melt from the mantle. As the magmas ascend, pressures and temperatures decrease and 1iquidus conditions change (Yoder and Tilley, 1962; Green and Ringwood, 1967). Most researchers believe that 
the final composition of basalts is due to the effects of low pressure or polybaric fractionation (e.g., O'Hara, 1965; Yoder and Tilley, 1962). A1though the nature of primary melt is controversial, each fractionating mineral leaves its own distinct fingerprint on the residual magma in the pattern of depletion or enrichment of the elemental (i.e., oxide) chemistry.

Speculations on the petrogenesis of the lavas of Tumblebug Creek and High Cascade lavas

The lavas of Tumblebug Creek and the High Cascade lavas are quite similar in their major and trace element chemistry. The only major difference is the tendency for the most mafic of the High Cascade lavas to be slight1y more mafic than the most mafic flows of the lavas of Tumblebug Creek. This is reflected in the number of olivine normative analyses of the former in comparison to those of the latter unit (Figure 5.7).

In the following discussion of the petrogenesis of the lavas of Tumblebug Creek and High Cascade lavas, the origins of P-PHL (the High Cascade high-K basalt) and PNotch (the High Cascade andesite) are excluded. These two samples will be discussed separately later in this section. Iron and magnesium show strong, sub-equal depletion (each close to 2 (weight) percent over the $51.5-53.8 \%$ silica range), indicative of fractionation of a ferromagnesian mineral (Figure 5.1a,b). Nicke1 and 
chromium also exhibit strong depletion (Figure 5.6). Although olivine is the principal phenocryst mineral in all these lavas, olivine fractionation is problematical. The $2 \mathrm{~V}$ of all olivine phenocrysts examined petrographically were very close to 900 , indicating a forsterite-fayalite ratio close to 86:14 (Deer and others, 1966). An olivine of similar forsteritic composition (see Table 5.4) contains a $\mathrm{FeO} * / \mathrm{MgO}$ weight ratio of 0.33 . For small quantities of olivine removal, iron would be mildly depleted while silica would be mildly enriched. Magnesium would be strongly depleted. Consequently, olivine fractionation should dramatically increase the $\mathrm{FeO} * \mathrm{MgO}$ ratio with an increase in silica. Neither the lavas of Tumblebug Creek nor the High Cascade lavas exhibit increase of $\mathrm{FeO}^{*} / \mathrm{MgO}$ with increasing silica (see Figure 5.4b). Co-fractionation of olivine with iron-titanium oxide would mitigate the enrichment of iron in the residual magmas, but the lack of cobalt depletion (Figure 5.6b) argues against either olivine or iron-titanium oxide fractionation. The distribution coefficient (D) for cobalt in the olivine molecular structure is about 6 at $1100 \circ$, and the value of D for cobalt in titaniferous magnetite is in the range 5.8 $-17$

Augite fractionation would cause a dramatic decrease in the $\mathrm{CaO} / \mathrm{A} 1203$ ratio in residual liquids due to the preferential inclusion of calcium into the lattice and exclusion of aluminum into the liquid (see Table 5.4). 
Figure $5.8 \mathrm{a}$ shows the $\mathrm{CaO} / \mathrm{A} 1203$ ratio in these rocks is almost constant (about 0.5 ).

Plagioclase fractionation can be identified by decrease of alumina and strontium, a slight decrease in calcium, and an increase in the Si02/A1203 ratio. No definite trend is visible in the alumina and strontium fields (Figures $5.2 c$ and $5.5 c$ ) and the silica/alumina ratio is constant (Figure 5.9). Co-fractionation of plagioclase with augite would cause the observed (slight) depletion of calcium from the melt, but obscure the other te11-tale characteristics of either individual mineral. However, it would be difficult to account for the decrease in total iron under this hypothesis. Furthermore, inspection of Table 5.4 indicates that both plagioclase and augite would deplete the melt in calcium with respect to iron. Figure $5.8 \mathrm{~b}$ shows strong enrichment of the calcium/total iron ratio in the residual melt. Therefore co-precipitation of augite and plagioclase in these lavas is unlikely.

Amphibole crystallization is not expected in lavas of this mafic character, and therefore is not likely to have caused the observed chemical trends.

Fractionation of orthopyroxene has many of the same characteristics as olivine. The $\mathrm{FeO}^{*} / \mathrm{MgO}$ ratio is 0.53 (Table 2), and the silica content is only slightly higher than the expected chemistry of the magma from which it is separating (perhaps similar to P-616, Appendix I). Separation of small amounts of hypersthene from mafic lavas 

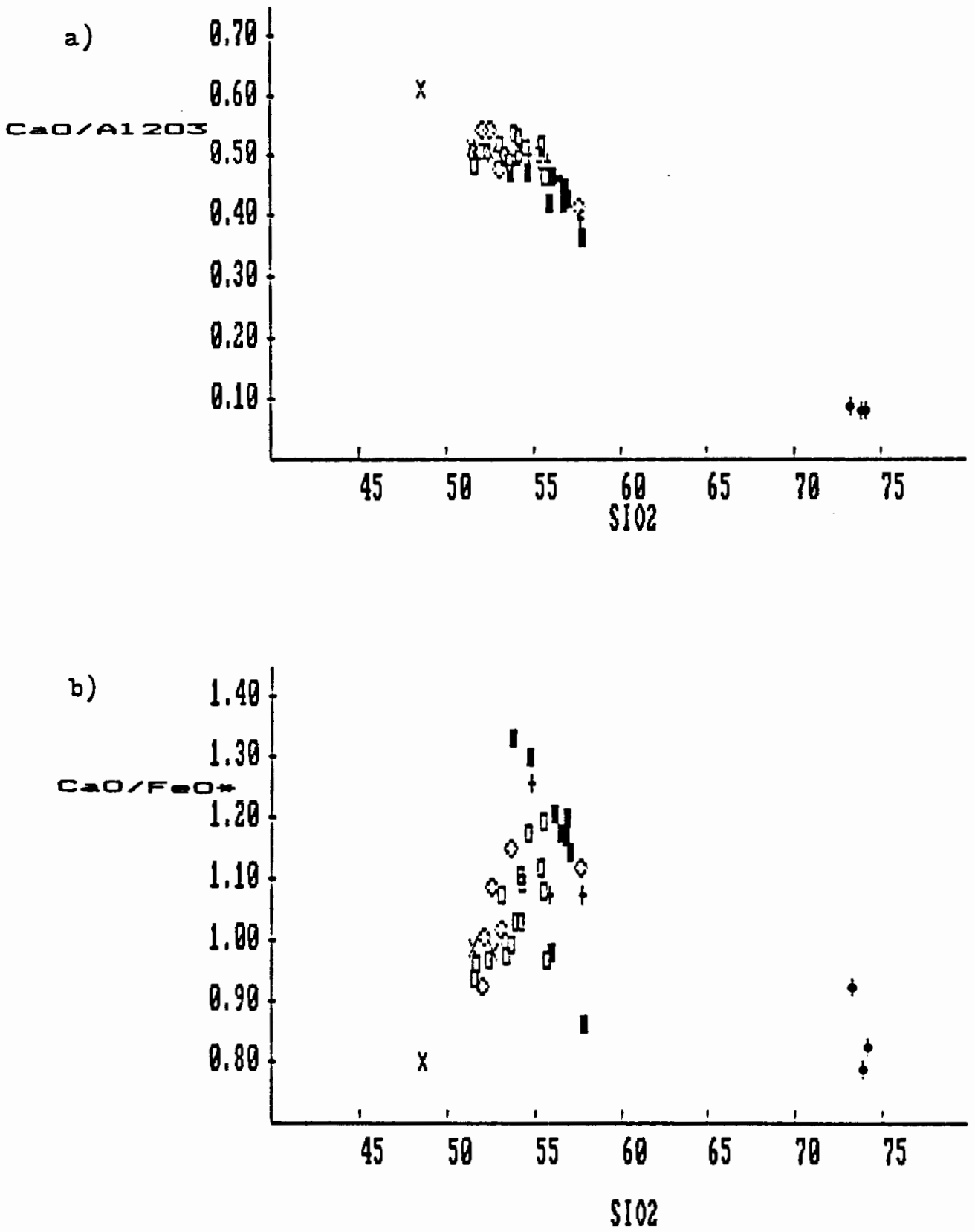

Figure 5.8. S1lica versus $\mathrm{CaO} / \mathrm{Al}_{2} \mathrm{O}_{3}$ and $\mathrm{CaO} / \mathrm{FeO}$. Symbols as in Table 5.1 . 


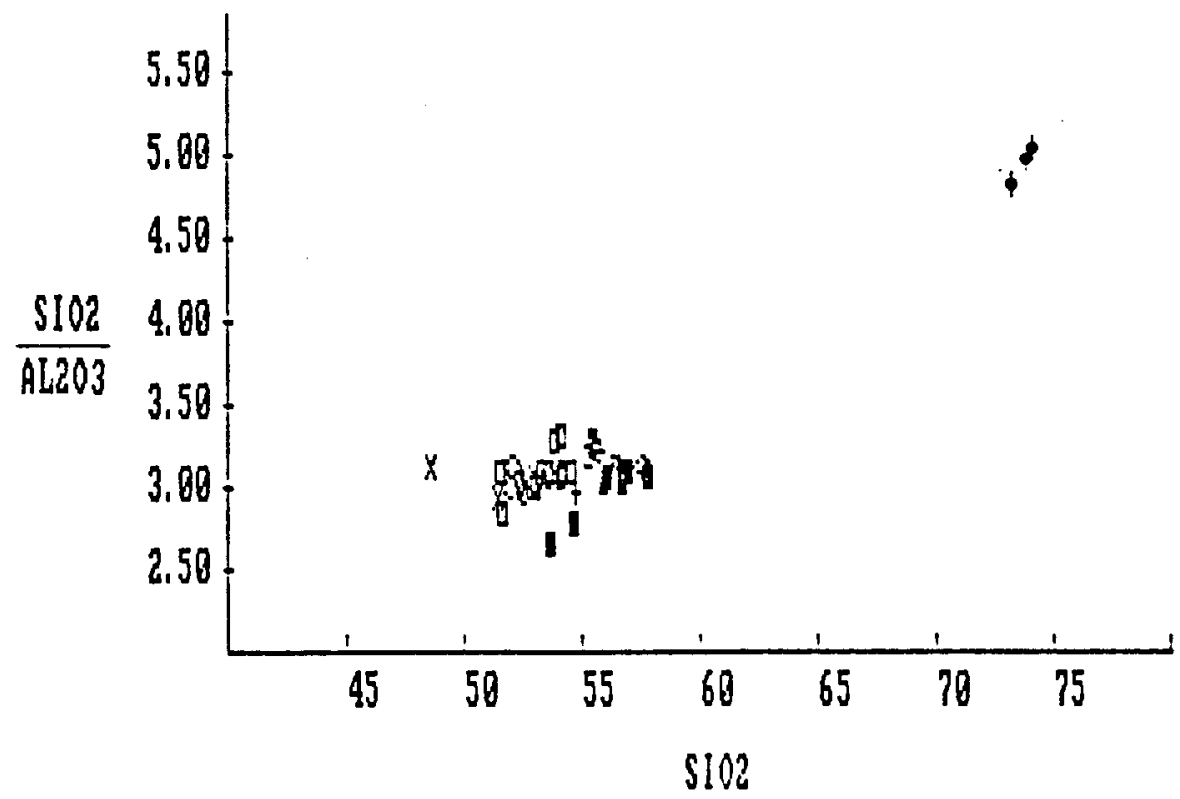

Figure 5.2. Silica versus $\mathrm{SiO}_{2} / \mathrm{Al}_{2} \mathrm{O}_{3}$. Symbols as in Table 5.1 . 
would have little effect on (or very slightly lower) the silica of a mafic residual liquid, while FeO*/MgO would very slowly increase. Any $\mathrm{FeO} / \mathrm{MgO}$ enrichment might be masked by the apparent stability of the silica content of the fractionating 1iquid. Hypersthene fractionation would not affect the CaO/A1203 (Figure 5.8a), because it accepts neither calcium nor aluminum. It would cause the observed sharp increase in the calcium/iron ratio (Figure 5.8b).

Trace element data also supports the hypersthene separation hypothesis. In the lavas of Tumblebug Creek nickel and chromium decrease by factors of .3 and .2 , respectively, from their highest concentrations (over a $\mathrm{MgO}$ range from $6.8 \%$ to $4.5 \%$; see Figures $5.6 a, c)$. Cobalt shows considerable scatter but with an overall flat trend (Figure 5.6b). When compared over the same range of magnesium content the High Cascade lavas have identical nickel, chromium, and cobalt differentiation patterns. Nickel is preferentially incorporated into the crystal structures of al1 the mafic volcanic minerals with respect to coexisting liquid, but is especial1y included into the olivine crystal structure. Cobalt has a strong affinity for olivine as wel1 (Irving, 1978). Chromium, depending on the temperature and oxygen fugacity of the magma, may have either a weak affinity or exclusion from olivine, based on the compilations in Irving (1978) and Priest (1979). Therefore, even though olivine is a phenocryst phase, one cannot account for the sharp decrease of both nickel and 
chromium and apparent lack of strong depletion of cobalt by olivine fractionation .

Fractionation of orthopyroxene is capable of producing the trace element pattern present in this unit. Irving (1978) lists distribution coefficients of $1.9-3.1$ for nickel (disregarding the nonconforming high and low extreme values), $>2$ for chromium under most temperature and oxygen fugacity conditions, and $1.0-1.4$ for cobalt.

Hypersthene was not observed in the lavas of Tumblebug Creek or the High Cascade lavas of the Willamette Pass area. It is a common, if minor, component of equivalent High Cascade basaltic andesites (and at least one basalt) in the North Santiam River area, near Mt. Jefferson (unpublished data of the author).

The absence of hypersthene in natural basalts has been considered a problem in the hypothesis of hypersthene fractionation from basaltic liquids (Basaltic Volcanism Study Project, 1981). Many researchers believe basaltic magmas originate as partial melts of peridotite mantle (Nicholls and Ringwood, 1973; Green and Ringwood, 1967; Ringwood, 1982). High pressure melting experiments on natural peridotites (or synthetic analogs) consistently show olivine +/- orthopyroxene on the liquidus, depending on the degree of partial fusion attained (e.g., Mysen and Kushiro, 1977; Mysen and Boettcher, 1975). Under equilibrium conditions, a partial melt will be saturated 
with the components of the country rock in which it is in contact (for small degrees of partial melting).

Green and Ringwood (1967) performed melting experiments on an olivine tholeite, an olivine basalt, a picrite basalt and an alkali basalt that possibly could represent primary mantle melts. They showed that orthopyroxene was a liquidus mineral in the olivine tholeite, olivine basalt, and the alkali olivine basalt at high pressures (12 to $23 \mathrm{~kb}$ ). Green and Ringwood (1967) indicate that orthopyroxene plays a dominant role in the early stages of fractionation in the 12 to $23 \mathrm{~kb}$ interval where olivine is unstable. They also conclude that it is possible to derive residual liquids with either clinopyroxene $+/$ - orthopyroxene on the liquidus with no olivine at $9 \mathrm{~kb}$. Olivine is in reaction relationship with the 1iquid under these ( $9 \mathrm{~kb}$ ) conditions.

0'Hara (1968) showed that at high pressure the crystallization field of olivine contracts, with a simultaneous expansion of the orthopyroxene field. Therefore, if hypersthene is a liquidus mineral at high pressure in a basaltic melt it may well enter the olivine stability field at lower pressures.

Yoder and Tilley (1962) showed that at moderate pressures ( $10 \mathrm{~kb}$ ) a thermal boundary along the enstatitediopside-albite plane of the basalt tetrahedron prevented olivine tholeiite compositions from producing quartz tholeiites by fractionation. At low pressures, however, 
the thermal divide is shifted to the olivine-diopsidealbite plane, and the fractionation path from olivine tholeite to quartz tholeite is no longer prevented. Both olivine tholeites and quartz tholeites occur in the High Cascade lavas, and the lavas of Tumblebug Creek appear to be a slightly less mafic but otherwise chemically equivalent series. It is unlikely that two units so chemically similar with respect to all the element abundances could result from different differentiation processes.

Seismic refraction data indicate the crustal thickness under the central Oregon Cascade Range is about $44 \mathrm{~km}$ (Leaver and others, 1984). This finding supported earlier seismic refraction studies by Wegener and others (1980) and gravity data of Thirukaval and others (1970) and Deh1inger and others (1968). Therefore ortho- and clinopyroxene would be expected to be liquidus minerals of magma at upper mantle depths. The most likely scenario for the formation of these lavas is partial melting of a peridotite in the upper mantle, and the continuous and complete removal $+/-$ reaction of hypersthene into upper crustal conditions.

\section{Discussion of samples P-PHL and P-Notch}

Sample P-PHL has alkaline (potasic suite)

characteristics. It has relatively high magnesium, titanium, potassium, iron, and calcium compared with the other High Cascade lavas. These elemental abundances occur 
at the expense of low silica, alumina, and sodium. The magnesium number is high $(0.64)$ and the $\mathrm{Ca} /(\mathrm{Ca}+\mathrm{Na})$ ratio is also high compared with the rest of the unit. Based on major and minor element chemistry, P-PHL appears to be a primitive magma. Primitive magma would be expected to have high compatible and low incompatible trace element concentrations. P-PHL has moderate nickel and cobalt concentrations and modest enrichment in chromium. Rubidium is below standard atomic absorbtion detection limits, surprising in view of the high potassium of the sample. Barium and strontium are at moderate concentrations compared to other lower High Cascade lavas analyzed in Priest and others (1983). The trace element chemistry, then, shows little deviation from the other mafic High Cascade lavas.

The major and minor element chemistry, low rubidium and moderate abundances of the other incompatible elements do not support crustal contamination hypotheses to explain the origin of P-PHL, nor do they support fluid enrichment in the mantle. O'Hara (1968) suggested that the various volcanic associations could be derived from similar parent magmas by variations in the rates of ascent and the depths at which the magma is allowed to equilibrate with the environment. No fractionation or partial melting scheme could derive the other High Cascade lavas (or lavas of Tumblebug Creek) from this primitive lava. Any fractionating mineral that increases the silica content 
would tend to increase the potassium as well. It is evident, therefore, that P-PHL has undergone a different genesis than the other time-equivalent lavas of Willamette Pass.

P-Notch, the High Cascade andesite, plots on the extension of the trend defined by the High Cascade lavas and lavas of Tumblebug Creek on many of the attached chemica1 diagrams. However, sodium, aluminum, nickel and strontium are offset higher than the trend (Figures 5.2b,c, $5.5 c$, and 5.6c). The higher strontium, sodium and aluminum suggest plagioclase enrichment in P-Notch, and plagioclase is indeed a phenocryst phase. Calcium and magnesium are depleted in relation to the High Cascade lavas-1avas of Tumblebug Creek trend (Figures $5.1 \mathrm{~b}$ and $5.2 \mathrm{a}$ ), and the sample falls below the trend on the CaO/Al203 diagram (Figure 5.8a). P-Notch is the product of augite fractionation (accounting for the calcium and magnesium depletion) and plagioclase enrichment. In view of this, the high nickel of this sample (Figure 5.6c) indicates it has undergone a different genesis from the other High Cascade lavas analyzed here.

Speculations on the petrogenesis of the Lavas of Moss Mountain

There is considerable overlap in the range of silica contents of the lavas of Moss Mountain and the lavas of Tumblebug Creek. Yet there are usually three minerals on 
the liquidus at the time of eruption of the lavas of Moss Mountain (plagioclase, and two of the following: augite, hypersthene, hornblende, or olivine). Only olivine is present in a11 the lavas of Tumblebug Creek. With three minerals on the liquidus at time of eruption, it is difficult to constrain hypotheses on the origin of these lavas.

As noted previously, the lavas of Moss Mountain have lower K20 and incompatible trace elements ( $R b, B a, S r$ ) when compared at the same $\mathrm{SiO} 2$ or MgO content than either the lavas of Tumblebug Creek or the High Cascade lavas. They are considered borderline $10 \mathrm{w}-\mathrm{K}$ andesites and basaltic andesites. Because large ion elements would be enriched rather than depleted in the generally more differentiated andesitic lavas, the lavas of Tumblebug Creek are not parenta 1 to the lavas of Moss Mountain.

Plagioclase fractionation is suggested by the simultaneous decrease in alumina, calcium, and sodium (Figure 5.2). Plagioclase is the only mineral capable of decreasing the alumina content of a magma (See Table 5.4) and increasing the silica/aluminuma ratio with increase in silica (Figure 5.9).

In contrast to the relative low concentrations of potassium, barium, and rubidium, strontium is higher than in silica-equivalent lavas of Tumblebug Creek and High Cascade lavas (Figure 5.5c). The most aluminous of these lavas are more aluminous than silica equivalent lavas of 
Tumblebug Creek and High Cascade lavas (Figure 5.2c). It seems likely, therefore, that the lavas of Moss Mountain were generated in a depleted region of the mantle, and were subsequently enriched by plagioclase accumulation. The analyzed samples range from basaltic andesite to low silica andesite. The predominance of basaltic andesites among the analyzed samples suggests that the added plagioclase was calcic in character. 


\section{CHAPTER 6}

\section{CONCLUSIONS}

The foregoing discussions have centered on the location of the study area at the junction of two hypothesized major structures at Willamette Pass, and the stratigraphy, structure, geophysical signatures, and petrology of the area.

Willamette Pass is located at the boundary of the Western Cascade and High Cascade physiographic provinces. The Western Cascade Range is a geomorphically mature volcanic region of primarily middle and upper Tertiary volcanic rocks. For the most part it represents a fossil volcanic arc, although a few, scattered, Pleistocene volcanic centers occur within the range.

The High Cascade Range is a geologically young (Quaternary) volcanic province that is geomorphically youthful. The lavas, overwhelmingly basalt to basaltic andesite in composition, have formed a primarily constructional terrane that has been modified principally by Pleistocene glaciation. This province is an active volcanic arc.

The boundary between the two provinces is marked by down-to-the-east faulting in several areas along the 
boundary, e.g. North Santiam River-Santiam Pass area (Black and others, in preparation) and the Horse Creek-McKenzie River area (e.g., F1aherty, 1981; Taylor, 1981). Woller and Black (1983) inferred a normal, down-to-the-east fault at Waldo Lake, just north of the present study area. As concluded in that study, the field evidence for continuation of the Waldo Lake fault southward into the present study area is equivocal. Suggestive features include 1) a 6-8 mgal gravity anomaly that is continuous with mapped fault zones to the north extends into the study area, 2) a middle to late Pliocene unconformity, prominent in the western two-thirds of the study area, loses definition and may not be present in the eastern third, and 3) middle Miocene andesites of the lavas of Moss Mountain crop out very close to, but not east of, the Cascade divide and the southern extension of the Waldo Lake structure. However, no fault is visible in the field. If it exists in upper Salt Creek, it may have been covered by Quaternary lavas.

Faulting in the Groundhog Creek area is not evident in middle Miocene rocks. If faulting is present, as suggested by gravity studies of Couch and others (1979, 1982a) and Pitts (1979) and reconnaissance level field work of Woller and Black (1983), the structure is in older rocks and is not visible in the field. Alternatively, the observed stratigraphic relations may be explained by homoclinal folding, with an eastward dip in this area. 
Faulting along the Eugene-Denio lineament of Lawrence (1976) is not supported by field evidence.

Heat flow in the High Cascade Range and in the eastern portion of the Western Cascades is very high, and has led to speculation that a 1) large, viable, geothermal resource may exist in that area, and 2) shallow, hot, possibly partially molten, masses may underlie areas within the heat flow anomaly (Blackwell and others, 1982). Although a large amount of geophysical data is present for the Willamette Pass area, deep drilling exploration will be required to truly understand the nature and viability of the geothermal resource.

The chemistry of the lavas of Willamette Pass exhibits a general, progressive trend to more mafic compositions with decreasing age. The oldest lavas exposed in the study area (probably 01 igocene to early Miocene in age) are variable in composition, ranging from basaltic andesite to rhyodacite, but the most common lithology is probably dacite or dacitic ashflow. Middle Miocene lavas are primarily andesite to basaltic andesite, although some basalts and dacites are present as we11. High Cascade lavas are predominantly basalt and basaltic andesite. However, when plotted on Harker variation diagrams, the lavas of the study area tend to plot in a cohesive or colinear field. This suggests either a similarity of genesis or a common source region. It is shown that the middle Miocene lavas of Tumblebug Creek are almost 
identical to the High Cascade lavas, and the more mafic compositions of the Oligocene-Miocene lavas, undifferentiated, analyzed here are very similar to the lavas of Moss Mountain. Analysis of major and trace element variation diagrams leads to the conclusions that 1 ) the lavas of Tumblebug Creek and High Cascade lavas were formed by the same process of differentiation (probably fractionation of orthopyroxene), and 2) the lavas of Moss Mountain and, by analogy, perhaps the Oligocene-Miocene lavas, undifferentiated, were modified principally by plagioclase enrichment. The colinear fields formed in the Harker diagrams presented in this study probably are a result of these two processes driving magmatic compositions toward a similar chemical nature. 


\section{REFERENCES}

Anderson, J. L., 1978, The stratigraphy and structure of the Columbia River Basalt in the Clackamas River drainage: Portland, Oregon, Portland State University master's thesis, $136 \mathrm{p}$.

Atwater, T., 1970, Implications of plate tectonics for the Cenozoic tectonic evolution of North America: Geological Society of America Bulletin, v. 81, p. 3513-3535.

Avramenko, W., 1981 , Volcanism and structure in the vicinity of Echo Mountain, central Oregon Cascade Range: Eugene, Oregon, University of Oregon master's thesis, $156 \mathrm{p}$.

Bacon, C. R., 1983, Eruptive history of Mount Mazama and Crater Lake caldera, Cascade Range, U.S.A.: Journal of Volcanology and Geothermal Research, v. 18, p. 57-115.

Baldwin, E. M., 1964, The geology of Oregon: Ann Arbor, Michigan, Edwards Brothers, Inc., 165 p.

Barnes, C. G., 1978, The geology of the Mount Bailey area, Oregon: Eugene, Oregon, University of Oregon master's thesis, $123 \mathrm{p}$.

Basaltic Volcanism Study Project, 1981, Basaltic volcanism of the terrestial planets: New York, Pergamon Press, Inc., $1,286 \mathrm{p}$.

Beeson, M. H., and Moran, M. R., 1979, Stratigraphy and structure of the Columbia River Basalt Group in the Cascade Range, Oregon, in Hull, D. A., investigator, and Riccio, J.F., ed., 1979, Geothermal resource assessment of Mount Hood: Oregon Department of Geology and Mineral Industries Open-File Report 0-79-8, p. 577 .

Black, G. L., Blackwe11, D. D., and Steele, J. L., 1983, Heat flow in the Oregon Cascades, in Priest, G. R., and Vogt, B. F., eds., Geology and Geothermal Resources of the central Oregon Cascade Range: Oregon Department of Geology and Mineral Industries Special Paper 15, p. 69-76. 
Black, G. L., Woller, N. M., and Ferns, M., Geology of the Santiam Junction area, Lane County, Oregon: Oregon Department of Geology and Mineral Industries Geological Map Series, in preparation.

Blackwell, D. D., Bowen, R. G., Hull, D. A., Riccio, J. F., and Steele, J. F., 1982, Heat flow, arc volcanism, and subduction in northern Oregon: Journal of Geophysical Research, v. 87, no. B10, p. 8735-8754.

Blackwell, D. D., Hu11, D. A., Bowen, R. G., and Steele, J. L., 1978, Heat flow of Oregon: Oregon Department of Geology and Mineral Industries Special Paper 4, 42 p.

Blackwel1, D. D., and Steele, J. L., 1983, A summary of heat flow studies in the Cascade Range: Geothermal Resources Council Transactions, v. 7, p. 233-236.

Brooks, C. K., 1976, The Fe203/Fe0 ratio of basalt analyses: an appeal for a standardized procedure: Bulletin of the Geological Society of Denmark, v. 25, p. 117-120.

Brown, D. E., Mclean, G. D., Priest, G. R., Woller, N. M., and Black, G. L., 1980a, Preliminary geology and geothermal resource potential of the Belknap-Foley area, Oregon: Oregon Department of Geology and Mineral Industries Open-File Report $0-80-2,58 \mathrm{p}$.

Brown, D. E., McLean, G. D., Woller, N. M., and Black, G. L., 1980b, Preliminary geology and geothermal resource potential of the Willamette Pass area, Oregon: Oregon Department of Geology and Mineral Industries Open-File Report 0-80-3, 65 p.

Byrne, J. V., Fowler,G. A., and Maloney, N. J., 1966, Uplift of the continental margin and possible continental accretion off Oregon: Science, v. 154, p. 1654-1655.

Chayes, F., 1966, Alkaline and subalkaline basalts: American Journal of Science, v. 264, p. 128-145.

Chayes, F., 1969, The chemical composition of Cenozoic andesite, in McBirney, A. R., ed., Proceedings of the andesite conference: Oregon Department of Geology and Mineral Industries Bulletin 69, p. 1-10.

Christiansen, R. L., and McKee, E. H., 1978, Late Cenozoic volcanic and tectonic evolution of the Great Basin and Columbia intermontane regions, in Smith, $R$. B., and Eaton, G. P., eds., Cenozoic tectonics and regional 
geophysics of the western Cordillera: Geological Society of America Memoir 152, p. 283-311.

Connard, C. G., 1980, Analysis of aeromagnetic measurements from the central Oregon Cascades: Corvallis, Oregon, Oregon State University master's thesis, 101 p.

Conrey, R. M., 1985, Volcanic stratigraphy of the Deschutes Formation, Green Ridge to F1y Creek, north-central Oregon: Corvallis, Oregon, Oregon State University master's thesis, $345 \mathrm{p}$.

Couch, R. W., 1979, Geophysical inivestigations of the Cascade Range in central Oregon: U.S. Geological Survey Extramural Geothermal Research Program, Final Report, 95 p.

Couch, R. W., and Lowell, R. P., 1971, Earthquakes and seismic energy release in Oregon: Oregon Department of Geology and Mineral Industries, Ore Bin, v. 33, p. 6184 .

Couch, R. W., Pitts, G. S., Gemperle, M., Braman, D. E., and Veen, C. A., 1982a, Gravity anomalies in the Cascade Range in Oregon: Structural and thermal implications: Oregon Department of Geology and Mineral Industries Open-File Report 0-82-9, 43 p.

Couch, R. W., Pitts, G. S., Gemperle, M., Veen, C. A., and Braman, D. E., 1982 b, Residual gravity maps of the northern, central and southern Cascade Range, Oregon, $121000^{\prime}$ to $122030^{\prime} \mathrm{W} .42000^{\prime}$ to $45045^{\prime} \mathrm{N} .:$ : Oregon Department of Geology and Mineral Industries Geologica1 Map Series GMS-26, scale 1:250,000.

Deer, W. A., Howie, R. A., and Zussman, J., 1966, An introduction to the rock forming minerals: London, England, Longman Group Limited, 528 p.

Dehlinger, P., Couch, R. W., and Gemperle, M., 1968, Continental and oceanic structure from the Oregon coast westward across the Juan de Fuca Ridge, in Symposium on continental margins and island ar $\overline{c s}$, $3 \mathrm{rd}$, Zurich, v. 5, no. 4, pt. 2, p. 1079-1090.

Drake, E., 1982, Tectonic evolution of the Oregon continental margin: Oregon Department of Geology and Mineral Industries, Oregon Geology, v. 44, p. 15-21.

Drummond, K. J., Moore, G. W., Golovchenko, X., Larson, R. L., Pitman, W. C., III, Rinehart, W. A., Simkin, T., and Siebert, L., 1981, Plate tectonic map of the 
circum-Pacific region: Tulsa, Oklahoma, American Association of Petroleum Geologists.

Ewart, A., 1976, Mineralogy and chemistry of modern orogenic lavas-some statistics and implications: Earth and Planetary Science Letters, v. 31, p. 417-432.

Ewart, A., 1982, The mineralogy and petrology of TertiaryRecent orogenic volcanic rocks: with special reference to the andesitic-basaltic compositional range, in Thorpe, R.S., ed., Andesites: Orogenic andesites and related rocks: New York, John Wiley and Sons, p. 2587.

Flaherty, G. M., 1981, The Western Cascade-High Cascade transition in the McKenzie Bridge area, central Oregon Cascade Range: Eugene, Oregon, University of Oregon master's thesis, $178 \mathrm{p}$.

Furlong, K., Chapman, D. S., and Alfeld, P. W., 1982, Thermal modeling of the geometry of subduction with implications for the tectonics of the overriding plate: Journal of Geophysical Research, v. 87, p. $1786-1802$.

Gi11, J. B., 1978, Role of trace element partition coefficients in models of andesite genesis: Geochimica et Cosmochimica Acta, v. 42, 709-724.

Green, D. H., and Ringwood, A. E., 1967, The genesis of basaltic magmas: Contributions to Mineralogy and Petrology, v. 15, 103-190.

Hales, P. 0., 1975, Geology of the Green Ridge area, Whitewater River Quadrangle, Oregon: Corvaliis, Oregon, Oregon State University master's thesis, $90 \mathrm{p}$.

Hammond, P. E., 1979, A tectonic model for evolution of the Cascade Range, in Armentrout, J. M., Cole, M. R., and Terbest, H., Jr., eds., Cenozoic paleogeography of the western United States: Pacific Coast Paleogeography Symposium No. 3, Anaheim, California., Society of Economic Paleontologists and Mineralogists, Pacific Section, p. 219-237.

Hammond, P. E., Anderson, J. L., and Manning, K. J., 1980 , Guide to the geology of the upper Clackamas and North Santiam Rivers area, northern Oregon Cascade Range, in Oles, K. F., Johnson, J. G., Niem, A. R., and Niem, W. A., eds., Geologic field trips in western Oregon and wouthwestern Washington: Oregon Department of Geology and Mineral Industries Bulletin 101, p. 133-167. 
Hammond, P. E., Geyer, K. M., and Anderson, J. L., 1982, Preliminary geologic map and cross sections of the upper Clackamas and North Santiam River area, northern Oregon Cascade Range: Portland, Oregon, Portland State University Department of Earth Sciences, scale $1: 62,500$.

Hart, W. K., Aronson, J. L., and Mertzman, S. A., 1984, Areal distribution and age of low-K, high-alumina olivine tholeiite magmatism in the northwestern Great Basin: Geological Society of America Bulletin, v. 95, p. $186-195$.

Hart, W. K., and Mertzman, S. A., 1983, Late Cenozoic volcanic stratigraphy of the Jordan Valley area, southeastern Oregon: Oregon Department of Geology and Mineral Industries, Oregon Geology, v. 45, p. 15-19.

Irvine, T. N., and Baragar, W. R. A., 1971, A guide to the chemical classification of the common volcanic rocks: Canadian Journal of Earth Sciences, v. 8, p. 523-548.

Irving, A. J., 1978, A review of experimental studies of crystal/liquid trace element partitioning: Geochimica et Cosmochimica Acta, v. 42, p. 743-770.

Iyer, H. M., 1985, Characteristics of Cascades magmatic systems determined from teleseismic-residual studies, in Guffanti, M., and Muffler, L. J. P., eds.,

Proceedings of the workshop on geothermal resources of the Cascade Range: U.S. Geological Survey Open-File Report 85-521, p. 53-55.

Jakes, P., and White, A. J. R., 1972, Major and trace element abundances in volcanic rocks of orogenic areas: Geological Society of America Bulletin, v. 83, p. $29-39$

Jan, M. Q., 1967, Geology of the McKenzie River valley between the South Santiam Highway and the McKenzie Pass Highway, Oregon: Eugene, Oregon, University of Oregon master's thesis, $70 \mathrm{p}$.

Kienle, C. F., Nelson, C. A., and Lawrence, R. D., 1981, Faults and lineaments of the southern Cascades, Oregon: Oregon Department of Geology and Mineral Industries Special Paper 13, 23 p.

Kuno, H., 1966, Lateral variation of basalt magma typle across continental margins and island arcs: Bulletin Volcanologique, v. 29, p. 195-222. 
Lawrence, R. D., 1976, Strike-slip faulting terminates the Basin and Range province in Oregon: Geological Society of America Bulletin, v . 87, p. 846-850.

Leaver, D. S., Mooney, W. D., and Kohler, W. M., 1984, A seismic refraction study of the Oregon Cascades: Journal of Geophysical Research, v. 89, no. B5, p. $3121-3134$.

Leeman, W. P., and Rogers, J. J. W., 1970, Late Cenozoic alkali-olivine basalts of the Basin-Range province, U.S.A.: Contributions to Mineralogy and Petrology, v. 25, p. $1-24$.

LeMaitre, R. W., 1976, Some problems of the projection of chemical data into mineralogical classifications: Contributions to Mineralogy and Petrology, v. 56, p. $181-189$.

Long, M. T., and Leverton, M. A., 1984, Pleistocene interglacial volcanism: Upper Salmon Creek drainage, Lane County, Oregon: Oregon Department of Geology and Mineral Industries, Oregon Geology, v. 46, p. 131-138.

Luedke, R. G., and Smith, R. L., 1982, Map showing distribution, composition, and age of late Cenozoic volcanic centers in Oregon and Washington: U.S. Geological Survey Miscellaneous Investigation Series Map I-1091-D.

Macleod, N. S., and Sherrod, D. R., Geologic transect of the Cascade Range: unpublished field trip guide, American Geophysical Union meeting, Corvallis, Oregon, 1984 .

MacLeod, N. S., Walker, G. W., and McKee, E. H., 1975, Geothermal significance of eastward increase in age of upper Cenozoic rhyolitic domes in southeastern Oregon, in Second United Nations Symposium on the Development and Use of Geothermal Resources, San Francisco, California, 1975, Proceedings: Washington, D.C., U.S. Government Printing Office, v. 1, p. 465-474.

Mariner, R. H., 1985, Geochemical features of Cascade hydrothermal systems, in Guffanti, M., and Muffler, L. J. P., eds., Proceedings of the workshop on geothermal resources of the Cascade Range: U.S. Geological Survey Open-File Report 85-521, p. 59-62.

Mariner, R. H., Swanson, J. R., Orris, G. J., Presser, J. S., and Evans, W. C., 1980, Chemical and isotopic data for water from thermal springs and wells of 
Oregon: U.S. Geological Survey Open-File Report 80$737,50 \mathrm{p}$.

Maynard, L. C., 1974, Geology of Mount McLough1in: Eugene, Oregon, University of Oregon master's thesis, $139 \mathrm{p}$.

McBirney, A. R., 1968, Petrochemistry of Cascade andesite volcanoes: Oregon Department of Geology and Mineral Industries Bulletin 62, p. 101-107.

McKee, E. H., Duffield, W. A., and Stern, R. J., 1983, Late Miocene and early Pliocene basaltic rocks and their implications for crustal structure, northeastern California and south-central Oregon: Geological Society of America Bulletin, v. 94, p. 292-304.

Miyashiro, A., 1974, Volcanic rock series in island arcs and active continental margins: American Journal of Science, v. 274, p. 321-355.

Mysen, B. 0., and Boettcher, A. L., 1975, Melting of a hydrous mantle. I. Phase relations of natural peridotite at high pressures and high temperatures as a function of controlled activities of water, carbon dioxide, and hydrogen: Journal of Petrology, v. 16, p. $520-548$.

Mysen, B. 0., and Kushiro, I., 1977, Compositional variations of coexisting phases with degree of melting of peridotite in the upper mantle: American Mineralogist, v. 62, p. 843-865.

Nicholls, I. A., and Ringwood, A. E., 1973, Effect of water on olivine stability in tholeiites and the production of silica saturated magmas in the island arc environment: Journal of Geology, v. 81, p. 285-300.

$0^{\circ}$ Hara, M. J., 1965, Primary magmas and the origin of basalts: Scottish Journal ot Geology, v. 1, p. 19-40.

0'Hara, M. J., 1968, The bearing of phase equilibria studies in synthetic and natural systems on the origin and evolution of basic and ultrabasic rocks: Earth Science Reviews, v. 4, p. 69-133.

Peck, D. L., Griggs, A. B., Schlicker, H. G., Wells, F. G., and Dole, H. M., 1964, Geology of the central and northern parts of the Western Cascade Range in Oregon: U.S. Geological Survey Professional Paper 449, 56 p.

Peterson, N. V., Groh, E. A., Taylor, E. M., and Stensland, D. E., 1976, Geology and mineral resources of 
Deschutes County, Oregon: Oregon Department of Geology and Minera1 Industries Bu1letin 89, $66 \mathrm{p}$.

Pitts, G. S., 1979, Interpretation of gravity measurements in the Cascade Mountains and adjoining Basin and Range province in central Oregon: Corvallis, Oregon, Oregon State University master's thesis, $186 \mathrm{p}$.

Priest, G. R., 1979, Geology and geochemistry of the Little Walker volcanic center, Mono County, California:

Corvallis, Oregon, Oregon State University doctoral dissertation, 229 p.

Priest, G. R., 1983, Geothermal exploration in the central Oregon Cascade Range: in Priest, G. R., and Vogt, B. F., eds., Geology and Geothermal Resources of the central Oregon Cascade Range: Oregon Department of Geology and Mineral Industries Special Paper 15, p. $77-87$.

Priest, G. R., 1985, Geothermal exploration in Oregon, 1984: Oregon Department of Geology and Mineral Industries, Oregon Geology, v. 47, p. 63-66, 69.

Priest, G. R., and Vogt, B. F., eds., 1983, Geology and Geothermal Resources of the central Oregon Cascade Range: Oregon Department of Geology and Mineral Industries Special Paper 15, 123 p.

Priest, G. R., and Woller, N. M., 1983, Geology of the Cougar Reservoir area, Lane County, Oregon, in Priest, G. R., and Vogt, B. F., eds., Geology and Geothermal Resources of the central Oregon Cascade Range: Oregon Department of Geology and Mineral Industries Special Paper 15, p. 39-48.

Priest, G. R., Woller, N. M., Black, G. L., and Evans, S. H., 1983, Overview of the Geology of the central Oregon Cascade Range, in Priest, G. R., and Vogt, B. F., eds., Geology and Geothermal Resources of the centra1 Oregon Cascade Range: Oregon Department of Geology and Mineral Industries Special Paper 15, p. 328 .

Ringwood, A. E., 1982, Phase transformations and differentiation in subducted 1 ithosphere: Implications for mantle dynamics, basalt petrogenesis, and crustal evolution: Journal of Geology, v. 90, p. 611-643.

Rollins, A., 1976, Geology of the Bachelor Mountain area, Linn and Marion Counties, Oregon: Corvallis, Oregon, Oregon State University master's thesis, $83 \mathrm{p}$. 
Sherrod, D. R., Moyle, P. R., Rumse, C. M., and MacLeod, N. S., 1983, Geology and mineral resource potential of the Diamond Peak Wilderness, Lane and Klamath

Counties, Oregon: U.S. Geological Survey Open-File Report OF-83-0661, 21 p.

Smith, A. L., and Carmichae1, I. S. E., 1968, Quaternary lavas from the southern Cascades, western U.S.A.: Contributions to Mineralogy and Petrology, v. 19, p. $212-238$.

Smith, G. A., and Taylor, E. M., 1983, The central Oregon High Cascade graben: What? Where? When?: Geothermal Resources Council Transactions, v. 7, p. 275-279.

Smith, J. G., Page, N. J., Johnson, M. G., Moring, B. C., and Gray, F., 1982, Preliminary geologic map of the Medford lo $x$ 2o quadrangle, Oregon and California: U.S. Geological Survey Open-File Report 82-955, scale $1: 250,000$.

Stauber, D. A., and Berge, P. A., 1985, Comparison of the P-velocity structures of Mt. Shasta, California, and Newberry volcano, Oregon [abs.]: EOS, American Geophysical Union Transactions, v. 66, p. 25 .

Taylor, E. M., 1968, Roadside geology, Santiam and McKenzie Pass Highways, Oregon, in Dole, H. M., ed., Andesite Conference guidebook: Oregon Department of Geology and Mineral Industries Bulletin 62, p. 3-33.

Taylor, E. M., 1973, Geology of the Deschutes Basin, in Beaulieu, J. D., field trip chairman, Geologic field trips in northern Oregon and southern Washington: Oregon Department of Geology and Mineral Industries Bulletin 77, p. 29-32.

Taylor, E. M., 1981, Centra1 High Cascade roadside geologyBend, Sisters, McKenzie Pass, and Santiam Pass, Oregon, in Johnson, D. A., and Donnelly-Nolan, J., eds., Guides to some volcanic terranes in Washington, Idaho, Oregon and southern California: U.S. Geological Survey Circular 838, p. 55-58.

Taylor, S. R., 1969, Trace element chemistry of andesites and associated calc-alkaline rocks: Oregon Department of Geology and Mineral Industries Bulletin 65, p. 4363 .

Thayer, T.P., 1939, Geology of the Salem Hills and the North Santiam River basin, Oregon: Oregon Department of Geology and Mineral Industries Bulletin 15, 40 p. 
Thirukaval, J. V., Berg, J. W., Jr., and Heinrichs, D. F.,

1970, Regional gravity of 0regon: Bulletin of the

Seismological Society of America, v. 81, p. 725-738.

Ui, T., 1972, Recent volcanism in Masaya-Granada area, Nicaragua: Bulletin Volcanologique, v. 36, p. 174-190.

Venkatakrishnan, R., Bond, J. G., and Kauffman, J. D., 1980, Geological linears of the northern part of the Cascade Range, Oregon: Oregon Department of Geology and Mineral Industries Special Paper 12,25 p.

Von Huene, R., and Kulm, L. D., 1973, Tectonic summary of leg 18, in Kulm, L. D., von Huene, R., and others, Initial reports of the Deep Sea Drilling Project, $v$. 18: Washington, D.C., U.S. Government Printing Office, p. $961-976$.

Walker, G. W., 1977, Geologic map of Oregon east of the 121 st meridian: U.S. Geological Survey Miscellaneous Investigations Series Map I-902, scale 1:500,000.

Walker, G. W., and Nolf, B., 1981, High Lava Plains, Brothers fault zone to Harney Basin, Oregon, in Johnson, D. A., and Donnel1y-Nolan, J., eds., Guides to some volcanic terranes in Washington, Idaho, Oregon and southern California: U.S. Geological Survey Circular 838, p. 105-111.

Weaver, C. S., Green, S. M., and Iyer, H. M., 1982, Seismicity of Mt. Hood and structure as determined from teleseismic P-wave delay studies: Journal of Geophysical Research, v. 87, p. 2782-2792.

Wegener, S. S., Mooney, W. D., and Healy, J. H., 1980, A long-range seismic refraction study of the High Cascades, Oregon [abs.]: EOS (American Geophysical Union Transactions), v. 61, p. 71 .

We11s, R. E., Engebretson, D. C., Snavely, P. D., Jr, and Coe, R. S., 1984, Cenozoic plate motions and the volcano-tectonic evolution of western Oregon and Washington: Tectonics, v. 3, p. 275-294.

Wells, F. G., and Peck, D. L., 1961, Geologic map of Oregon west of the 121 st meridian: U.S. Geological Survey Miscellaneous Investigations Series Map I-325, scale $1: 500,000$.

White, C. M., 1980, Geology of the Breitenbush Hot Springs quadrangle, Oregon: Oregon Department of Geology and Mineral Industries Special Paper 9, 26 p. 
White, C. M., and McBirney, A. R., 1978, Some quantitative aspects of orogenic volcanism in the Oregon Cascades, in Smith, R. B., and Eaton, G. P., eds., Cenozoic tectonics and regional geophysics of the western Cordillera: Geological Society of America Memoir 152, p. 369-388.

Williams, D. L., and Von Herzen, R. P., 1982, On the terrestrial heat flow and physicallimnology of Crater Lake, Oregon: Journal of Geophysical Research, v. 88, no. B2, p. 1094-1104.

Williams, H. and McBirney, A. R., 1969, Volcanic history of Honduras: University of California Publications in Geologica1 Sciences, v. 85, 99 p.

Woller, N. M., and Black, G. L., 1983, Geology of the Waldo Lake-Swift Creek area, Lane and Klamath Counties, Oregon, in Priest, G. R., and Vogt, B. F., eds., Geology and Geothermal Resources of the central Oregon Cascade Range: Oregon Department of Geology and Mineral Industries Special Paper 15, p. 57-68.

Woller, N. M., and Priest, G. R., 1983, Geology of the Lookout Point area, Lane County, Oregon, in Priest, G. R., and Vogt, B. F., eds., Geology and Geotherma1 Resources of the central Oregon Cascade Range: Oregon Department of Geology and Mineral Industries Special Paper 15, p. 49-56.

Yoder, H. S., Jr., 1969, Calcalkalic andesites: experimental data bearing on the origin of their assumed characteristics: Oregon Department of Geology and Mineral Industries Bulletin 65, p. 77-90.

Yoder, H. S., and Tilley, C. E., 1962, Origin of basalt magmas: An experimental study of natural and synthetic rock systems: Journal of Petrology, v. 3, p. 342-532.

Youngquist, W. L., 1980 , Geothermal gradient drilling, north-central Cascades of Oregon, 1979: Oregon Department of Geology and Mineral Industries Open-File Report $0-82-12,47 \mathrm{p}$. 


\section{APPENDIX I: CHEMICAL ANALYSES}

Map sample numbers $20,22,23,30$, and 34 were analyzed by standard induced argon coupled plasma techniques at the University of Utah Research Institute (Ruth Kroneman, analyst). A11 other samples were analyzed by standard atomic absorbtion at the University of Oregon (Christine McBirney, analyst).

map unit

map \#

fie1d \#

$\mathrm{SiO} 2$

$\mathrm{Ti} 02$

A 1203

$\mathrm{Fe} 203$

$\mathrm{FeO}$

$\mathrm{MnO}$

$\mathrm{MgO}$

Cao

$\mathrm{Na} 20$

$\mathrm{K} 20$

$\mathrm{H} 20+$

H 20 -

P205

Total

cation norms

Q

Or

$\mathrm{Ab}$

An

Di

Hy

01

Mt

I 1

A p

\section{1 igocene-Miocene} rhyodacites
01 igocene-Miocene lavas, undiff. 


\section{APPENDIX 1 (continued): CHEMICAL ANALYSES}

Map unit

map

$\mathrm{SiO} 2$

A 1203

$\mathrm{Fe} 203$

$\mathrm{FeO}$

$\mathrm{MnO}$

$\mathrm{MgO}$

$\mathrm{CaO}$

$\mathrm{Na} 20$

$\mathrm{K} 20$

$\mathrm{H} 20+$

H20-

P205

$$
1.25
$$$$
16.12
$$$$
6.02
$$$$
3.08
$$$$
.17
$$$$
6.40
$$$$
7.99
$$$$
3.18
$$$$
1.59
$$

.64 field \# $\quad 7$

8
$\mathrm{~T}-2$

$$
49.40 \quad 54.40
$$$$
1.36
$$

16.57

$$
6.38
$$$$
2.65
$$$$
.16
$$

5.37

8.62

3.48

1.05

.55

.63

.33

.39

.33

Total $95.84 \quad 100.59$

Cation norms

Q

Or

Ab

An

Di

Hy

01

$\mathrm{Mt}$

I 1

Ap
0

9.81

29.81

26.12

8.72

14.86

5.29

2.19

1.40

1.40
3.77

6.21

31.27

31.27

10.15

16.98

0

2.07

1.90

1.15
Lavas of Tumb1ebug Creek

$\begin{array}{rrrr}9 & 10 & 11 & 12 \\ \mathrm{~T}-3 & \mathrm{~T}-4 & \mathrm{~T}-7 & \mathrm{~T}-9\end{array}$

53.20

53.40

52.80

51.60

17.40

16.43

1.42

3.70

3.18

3.17

17.14

5.09

5.56

5.58

4.02

.16

.16

5. 19

5.21

6.56

5.32

.17

8.63

9.00

6.13

8.32

3.26

.67

3.67

.73

8.50

.66

99.34

99.21

99.60

98.66

Trace elements

$\begin{array}{lrrrrrr}\mathrm{Rb} & 25 & 14 & 11 & 6.5 & 5.0 & 6.2 \\ \mathrm{Ba} & 708 & 438 & 456 & 267 & 409 & 311 \\ \mathrm{Sr} & 745 & 819 & 854 & 759 & 815 & 569 \\ \mathrm{Co} & 42 & 48 & 65 & 55 & 66 & 53 \\ \mathrm{Ni} & 97 & 81 & 72 & 150 & 67 & 129 \\ \mathrm{Cr} & 156 & 154 & 106 & 224 & 106 & 133 \\ \mathrm{Zn} & 93 & 90 & 98 & 86 & 90 & 84 \\ \mathrm{Cu} & 66 & 71 & 68 & 72 & 54 & 62 \\ \mathrm{Li} & 13 & 11 & 11 & 8.3 & 9.5 & 8.8\end{array}$


APPENDIX 1 (continued): CHEMICAL ANALYSES

map unit

Lavas of Tumblebug Creek

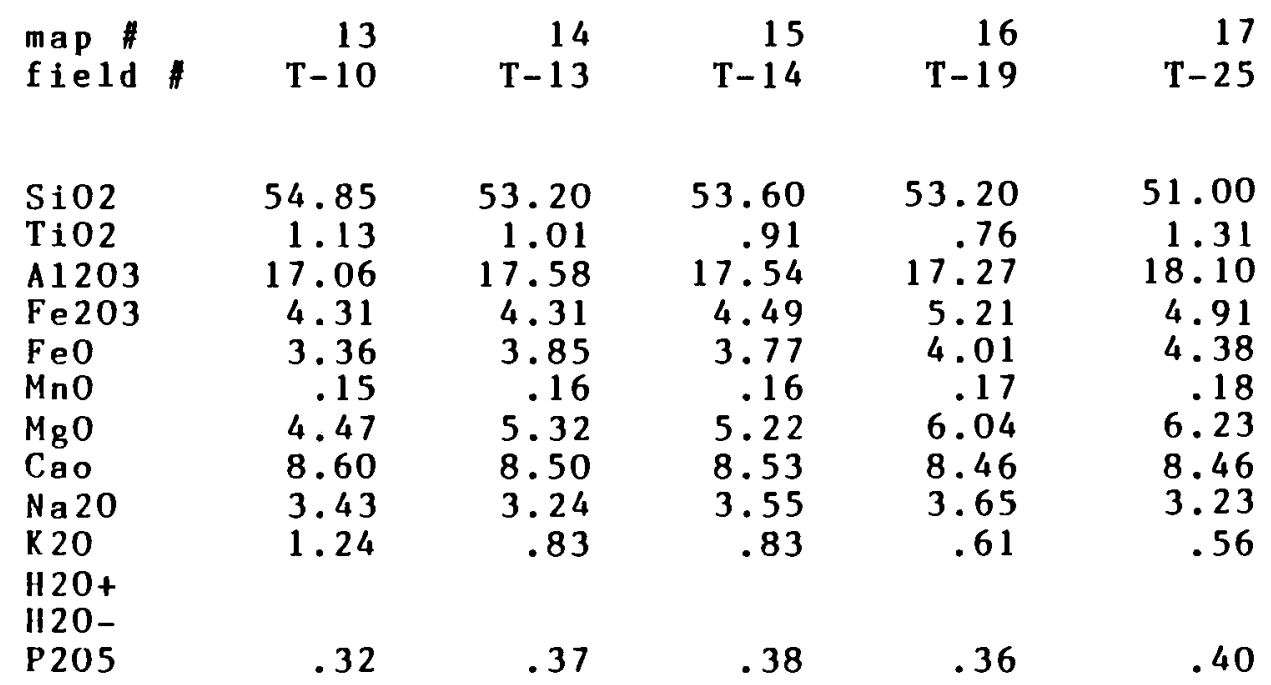

$\begin{array}{llllll}\text { Total } & 98.92 & 98.37 & 98.98 & 99.74 & 98.76\end{array}$

Cation norms

$\begin{array}{lrrrrr}\text { Q } & 5.07 & 3.96 & 2.93 & 1.21 & .87 \\ \text { Or } & 7.44 & 5.00 & 4.96 & 3.61 & 3.35 \\ \text { Ab } & 31.26 & 29.64 & 32.22 & 32.83 & 29.40 \\ \text { An } & 27.91 & 31.56 & 29.80 & 29.00 & 33.70 \\ \text { Di } & 10.62 & 7.15 & 8.38 & 8.56 & 4.96 \\ \text { IIy } & 13.61 & 18.52 & 17.69 & 20.83 & 22.81 \\ \text { O1 } & 0 & 0 & 0 & 0 & 0 \\ \text { Mg } & 1.82 & 1.95 & 1.95 & 2.15 & 2.20 \\ \text { I1 } & 1.60 & 1.43 & 1.28 & 1.06 & 1.85 \\ \text { Ap } & .68 & .79 & .80 & .76 & .85\end{array}$

Trace elements (ppm)

$\begin{array}{lrrrrr}\mathrm{Rb} & 21 & 10 & 10 & 6.2 & 2.0 \\ \mathrm{Ba} & 483 & 598 & 400 & 339 & 477 \\ \mathrm{Sr} & 508 & 538 & 560 & 598 & 538 \\ \mathrm{Co} & 46 & 58 & 42 & 52 & 62 \\ \mathrm{Ni} & 68 & 89 & 75 & 134 & 142 \\ \mathrm{Cr} & 96 & 118 & 101 & 190 & 270 \\ \mathrm{Zn} & 78 & 86 & 87 & 89 & 92 \\ \mathrm{Cu} & 77 & 73 & 75 & 58 & 53 \\ \mathrm{Li} & 9.1 & 9.1 & 9.9 & 9.8 & 9.2\end{array}$


APPENDIX I (continued): CHEMICAL ANALYSES

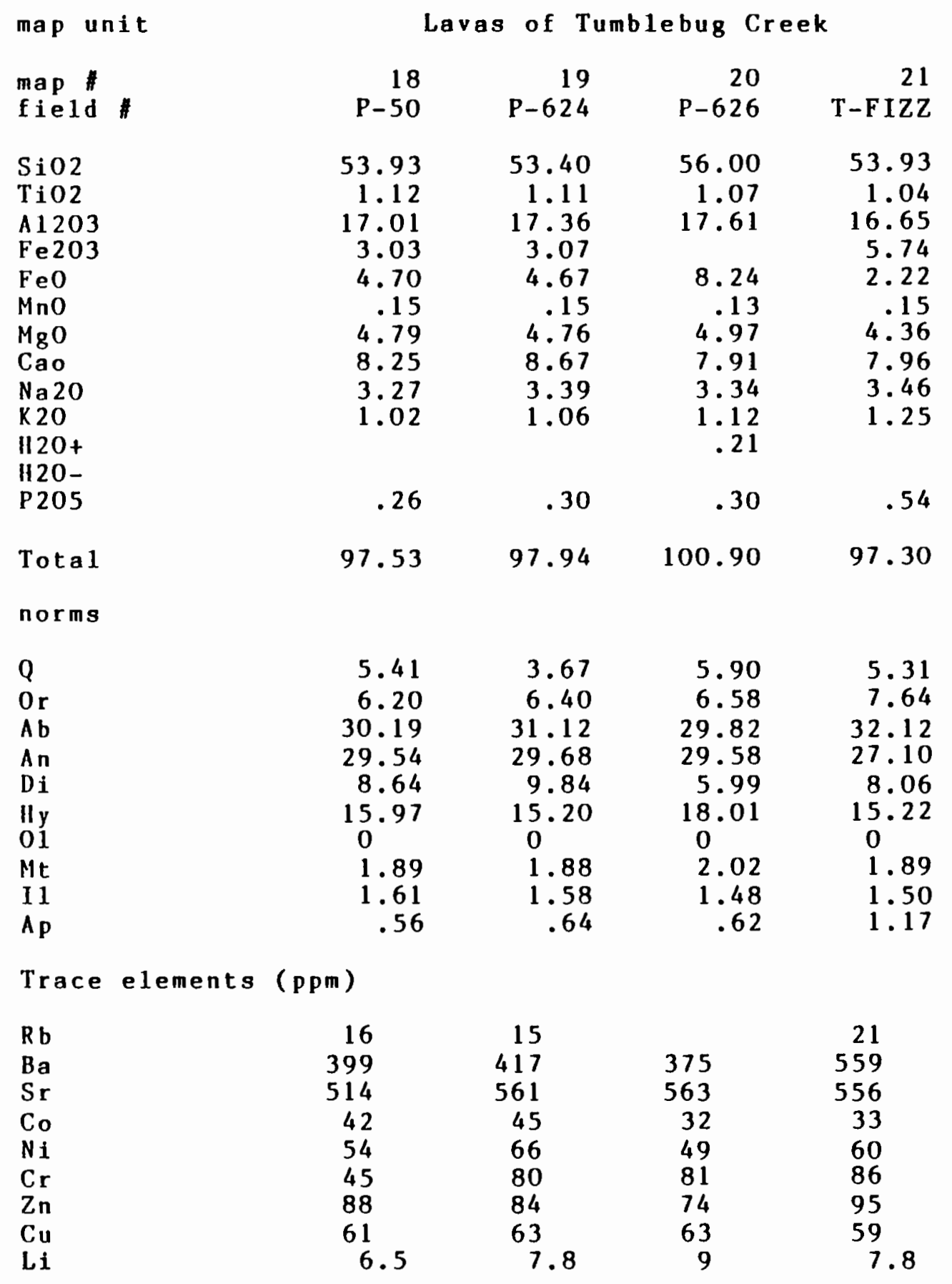


APPENDIX 1 (continued): CHEMICAL ANALYSES

map unit

$\begin{array}{lr}\text { map \# } & 22 \\ \text { fie } 1 \mathrm{~d} \# & \mathrm{P}-\mathrm{t} \text { mo }\end{array}$

$\mathrm{SiO} 255.70$

Ti02 0.95

A $1203 \quad 18.54$

$\mathrm{Fe} 203$

$\mathrm{FeO}$

$\mathrm{MnO}$

$\mathrm{MgO}$

Cao

$\mathrm{Na} 20$

K 20

H $20+$

H20-

P 205

7.83

0.13

4.48

7.63

3.28

0.89

0.89

0.30

Total 100.62

cation norms

$\begin{array}{lrrrrrrr}\text { Q } & 7.21 & 13.75 & 3.91 & 8.24 & 6.23 & 6.97 & 2.50 \\ \text { Or } & 5.28 & 4.81 & 3.62 & 4.28 & 4.15 & 4.44 & 2.71 \\ \mathrm{Ab} & 29.57 & 25.54 & 33.66 & 31.34 & 31.99 & 32.32 & 34.47 \\ \mathrm{An} & 33.38 & 32.74 & 35.13 & 33.94 & 32.08 & 31.59 & 36.88 \\ \mathrm{Di} & 2.13 & 0 & 6.58 & 2.63 & 6.59 & 5.85 & 6.45 \\ \mathrm{Hy} & 18.53 & 17.75 & 13.98 & 16.30 & 15.62 & 15.53 & 13.66 \\ \mathrm{O1} & 0 & 0 & 0 & 0 & 0 & 0 & 0 \\ \mathrm{Mt} & 1.94 & 1.96 & 1.71 & 1.64 & 1.71 & 1.70 & 1.73 \\ \mathrm{I1} & 1.33 & 1.35 & 1.04 & 1.31 & 1.33 & 1.28 & 1.31 \\ \mathrm{Ap} & .63 & .32 & .36 & . .32 & .39 & .32 & .30\end{array}$

Trace elements (ppm)

$\begin{array}{lrrrrrrr}\mathrm{Rb} & & & 6.5 & 6.5 & 6.5 & 8.0 & 3.0 \\ \mathrm{Ba} & 293 & 179 & 179 & 180 & 203 & 181 & 217 \\ \mathrm{Sr} & 694 & 602 & 744 & 744 & 784 & 763 & 885 \\ \mathrm{Co} & 34 & 17 & 43 & 44 & 48 & 51 & 144 \\ \mathrm{Ni} & 43 & 22 & 46 & 46 & 59 & 52 & 52 \\ \mathrm{Cr} & 44 & 34 & 197 & 44 & 54 & 57 & 8 \\ \mathrm{Zn} & 73 & 61 & 71 & 71 & 84 & 81 & 74 \\ \mathrm{Cu} & 66 & 34 & 98 & 32 & 53 & 62 & 98 \\ \mathrm{Li} & 6 & 13 & 7.1 & 7.1 & 6.3 & 7.1 & 8.4\end{array}$


APPENDIX 1 (continued): CHEMICAL ANALYSES

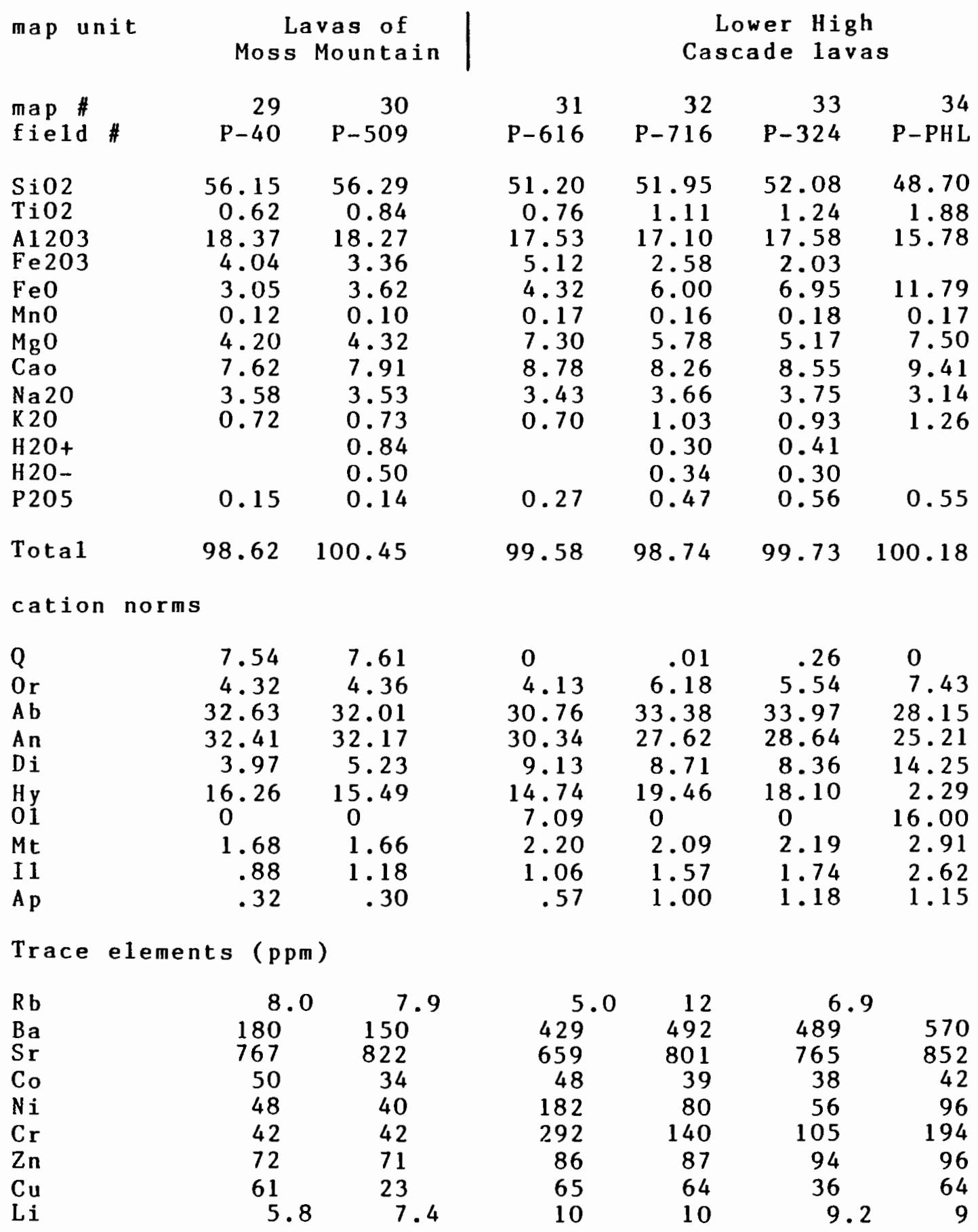


APPENDIX l (continued): CHEMICAL ANALYSES

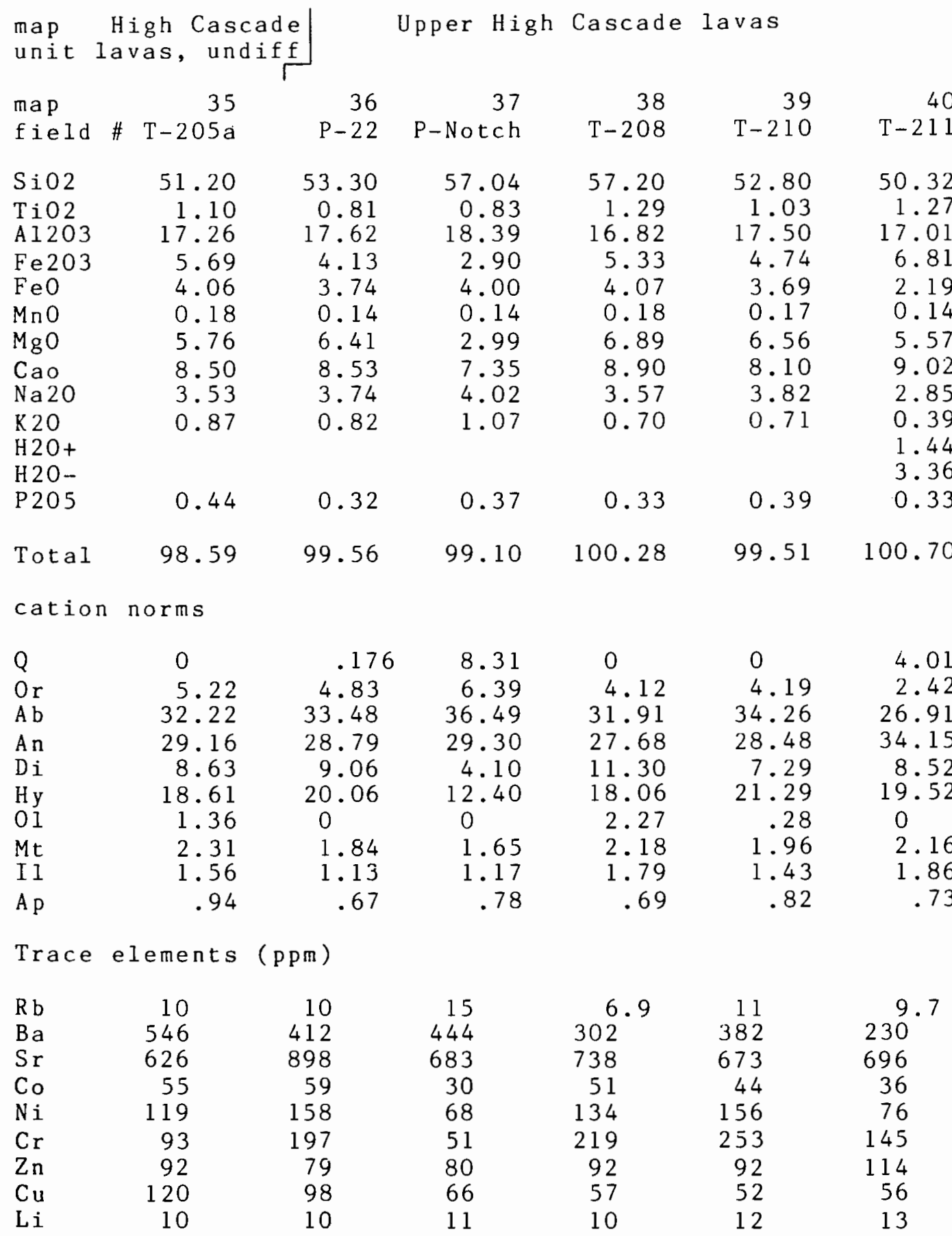


APPENDIX II

RADIOMETRIC DATE DATA

All dated materials were whole rock preparations.

$\begin{array}{rrrrrrrr}\text { map } & \text { field } & \begin{array}{c}\text { geologic } \\ \text { unit }\end{array} & \text { \%K20 } & \begin{array}{r}\text { \%Ar40 } \\ \text { atm }\end{array} & \begin{array}{r}\text { age } \\ \text { (m.y.) }\end{array} & +/- & \text { 1s } \\ 13 & \text { T-10 } & \text { Tmb } & 1.10 & 53 & 15.6 & +/- & 0.6 \\ 15 & \text { T-14 } & \text { Tmb } & 0.66 & 72 & 17.0 & +/- & 0.9 \\ 19 & \text { P-624 } & \text { Tmb } & 0.89 & 82 & 13.5 & +/- & 1.1 \\ 20 & \text { P-626 } & \text { Tmb } & 0.87 & 68 & 13.1 & +/- & 0.6 \\ 21 & \text { T-FIZ2 } & \text { Tmb } & 0.80 & 74 & 14.1 & +/- & 0.81 * \\ 30 & \text { P-509 } & \text { Tma } & 0.67 & 62 & 17.3 & +/- & 0.8 \\ 31 & \text { P-616 } & \text { Tpb } & 1.25 & 85 & 4.32 & +/- & 0.40 \\ 33 & \text { P-324 } & \text { Tpb } & 0.94 & 81 & 5.53 & +/- & 0.41 \\ 34 & \text { P-PHL } & \text { Tpb } & 0.90 & 76 & 5.56 & +/- & 0.34 \\ 36 & \text { P-22 } & \text { QTb } & 0.71 & 89 & 1.98 & +/- & 0.25 \\ 37 & \text { P-NOTCH } & \text { QTb } & 0.863 & 96 & 0.98 & +/- & 0.34 \\ 38 & \text { T-208 } & \text { QT } & 0.62 & 95 & 0.77 & +/- & 0.21 \\ 39 & \text { T-210 } & \text { QTb } & 0.81 & 99 & 0.17 & +/- & 0.48 \\ 40 & \text { T-211 } & \text { QT } & 0.68 & 97 & 0.97 & +/- & 0.46\end{array}$

* Date may be affected by low-grade rock alteration.

Constants used:

$\begin{aligned} \text { LambdaB } & =4.962 \times 10-10 / \mathrm{yr} \\ \text { Lambdae } & =0.581 \times 10-10 / \mathrm{yr} \\ 40 \mathrm{~K} / \text { Ktot } & =1.167 \times 10-4 \text { atom/atom }\end{aligned}$

Locations of dated samples

\begin{tabular}{|c|c|c|c|c|c|c|c|}
\hline $\begin{array}{l}\text { map } \\
\text { number }\end{array}$ & $\begin{array}{c}\text { 1atitude } \\
\left(N_{.}\right)\end{array}$ & $\begin{array}{c}\text { longitude } \\
(\text { (w.) }\end{array}$ & $\begin{array}{c}\text { Township } \\
\text { (S.) }\end{array}$ & $\begin{array}{r}\text { Range } \\
\text { (E.) }\end{array}$ & $1 / 4$ & $\begin{array}{l}\text { Section } \\
\text { of } 1 / 4\end{array}$ & of \\
\hline 13 & $43028^{\prime} 29^{\prime \prime}$ & 122016 '58"; & 24 & 4 & 24 & NE NE & SW \\
\hline 15 & $43030^{\prime} 53^{\prime \prime}$ & $122016^{\prime} 33^{\prime \prime} ;$ & 24 & 4 & 1 & SW SW & SE \\
\hline 19 & $43017 \cdot 40^{\prime \prime}$ & $122015 \cdot 27 " ;$ & 23 & 5 & 30 & $S E N E$ & SW \\
\hline 20 & $43017^{\prime} 38^{\prime \prime}$ & $122016^{\prime} 13^{\prime \prime} ;$ & 23 & 5 & 30 & SW SW & SW \\
\hline 21 & $43029^{\prime} 23^{\prime \prime}$ & $122016^{\prime} 8^{\prime \prime} ;$ & 24 & 5 & 18 & NW NW & SW \\
\hline 30 & $43034^{\prime} 6 "$ & $122014^{\prime} 20^{\prime \prime}$; & 23 & 5 & 19 & SW NE & NW \\
\hline 31 & 43031 ' 44 " & $122010 \cdot 30 "$; & 23 & 5 & 33 & SE SE & SE \\
\hline 32 & $43035^{\prime} 7 "$ & $122010^{\prime} 30^{\prime \prime}$; & 23 & 5 & 11 & SW SW & SW \\
\hline 34 & 43034 '15" & $122013^{\prime} 12^{\prime \prime}$; & 23 & 5 & 16 & SW SW & SE \\
\hline 36 & $43035^{\prime} 47^{\prime \prime}$ & $122013^{\circ} 47^{\prime \prime}$ & 23 & 5 & 9 & NW NW & NW \\
\hline 37 & $43034.41 "$ & $122010^{\prime} 52^{\prime \prime}$; & 23 & 5 & 14 & SE SE & NW \\
\hline 38 & $43029^{\prime} 11^{\prime \prime}$ & 122013 '24"; & 24 & 5 & 16 & NW SE & SW \\
\hline 39 & $43029 \cdot 36^{\prime \prime}$ & $122015^{\prime} 9^{\prime \prime}$; & 24 & 5 & 18 & SE SE & NE \\
\hline 40 & $43029^{\prime} 17^{\prime \prime}$ & $122015^{\circ} 9^{\prime \prime}:$ & 24 & 5 & 18 & SW NE & SE \\
\hline
\end{tabular}

